University of Michigan Law School

University of Michigan Law School Scholarship Repository

Articles

Faculty Scholarship

2016

\title{
Separations of Wealth: Inequality and the Erosion of Checks and Balances
}

Kate Andrias

University of Michigan Law School, kandrias@umich.edu

Available at: https://repository.law.umich.edu/articles/1724

Follow this and additional works at: https://repository.law.umich.edu/articles

Part of the Constitutional Law Commons, Law and Economics Commons, Law and Politics Commons, and the President/Executive Department Commons

\section{Recommended Citation}

Andrias, Kate. "Separations of Wealth: Inequality and the Erosion of Checks and Balances." U. Pa. J. Const. L. 18, no. 2 (2015): 419-504.

This Article is brought to you for free and open access by the Faculty Scholarship at University of Michigan Law School Scholarship Repository. It has been accepted for inclusion in Articles by an authorized administrator of University of Michigan Law School Scholarship Repository. For more information, please contact mlaw.repository@umich.edu. 


\title{
SEPARATIONS OF WEALTH: INEQUALITY AND THE EROSION OF CHECKS AND BALANCES
}

\author{
Kate Andrias ${ }^{* * *}$
}

\begin{abstract}
American government is dysfunctional: Gridlock, filibusters, and expanding presidential power, everyone seems to agree, threaten our basic system of constitutional governance. Who, or what, is to blame? In the standard account, the fault lies with the increasing polarization of our political parties. That standard story, however, ignores an important culprit: Concentrated wealth and its organization to achieve political ends. The only way to understand our current constitutional predicament—and to rectify it—is to pay more attention to the role that organized wealth plays in our system of checks and balances.
\end{abstract}

This Article shows that the increasing concentration of wealth and political power in the hands of the wealthy elite, and the concomitant decline of countervailing organizations, help explain the extent of executive power, the rise of gridlock, and, ultimately, the deterioration of effective checks and balances in the Federal Government. A core goal of constitutional structure-to promote democratic accountability and responsiveness to the broad citizenry-is severely compromised by the power wielded by organized wealth. Moderating partisanship will not alone solve constitutional dysfunction, nor will conventional good governance reforms like campaign finance regulation. Rather, this Article argues, the law should facilitate organizations of ordinary Americans that can serve as a countervailing check and prod in governance.

\section{TABLE OF CONTENTS}

INTRODUCTION .

\section{The Theory and Practice of Separating, Checking,} AND BALANCING POWER

II. THE POWER OF ORGANIZED WEALTH ..... 436

* Assistant Professor, Michigan Law School. For helpful comments, I would like to thank Reuven Avi-Yonah, Sam Bagenstos, Nicholas Bagley, Robert Bauer, Ashley Deeks, Willy Forbath, Daniel Halberstam, Scott Hershovitz, Don Herzog, Daryl Levinson, Ellen Katz, Nina Mendelson, Gabe Mendlow, Julian Mortenson, Bill Novak, Rick Pildes, David Pozen, Richard Primus, Daphna Renan, Gil Seinfeld, Kate Shaw, Mila Sohoni, Tabatha Abu ElHaj, and participants at workshops at Michigan, Emory, Loyola Chicago, NYU, and Stanford law schools. Rebecca Eisenbrey and Lexi Peacock provided excellent research assistance. Thanks also to the editors at the Journal of Constitutional Law and to the research librarians at the Michigan Law library. Finally, I wish to acknowledge the generous support of the William W. Cook Endowment of the University of Michigan.

** The online version of this Article contains a minor change from the print edition. This change does not affect the author's argument or any substantive portions of the text. 
A. Organized Wealth in Politics...................................... 437

B. Organized Wealth in the Branches ................................ 444

C. Organized Wealth in the Parties .................................... 452

D. A Coda: Outcomes for Governance................................ 456

III. ASSESSING THE "FIFTH BRANCH": THE EFFECTS OF ORGANIZED WEALTH ON EXECUTIVE POWER AND

LEGISLATIVE CAPACITY ....................................................... 461

A. Unified Government ................................................ 462

B. Divided Government and Gridlock................................. 471

C. Administrative Checks................................................. 475

\section{ORGANIZED WEALTH AND THE FUNCTIONS OF}

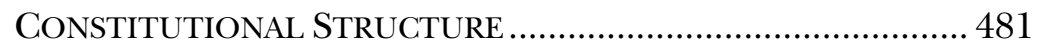

A. Functions of Constitutional Structure............................... 481

1. Liberty .............................................................. 481

2. Efficacy...................................................... 483

3. Democratic Accountability ...................................... 485

B. Reforming Constitutional Law .................................. 487

1. Enhanced Judicial Review ..................................... 487

2. Problems with Heightened Judicial Review .................. 491

C. Democratic Institutional Design and the Law of

Organization 493

1. From Moderation and Insulation to Participation and Organization ......................................................... 493

2. Building Countervailing Organization ..................... 499

\section{INTRODUCTION}

Everyone seems to agree: American government is dysfunctional. ${ }^{1}$ Politicians are continuously at each other's throats. Congress is paralyzed. Budgets are not enacted; legislation is not passed. Americans' faith in government suffers.

What is to blame? According to the standard narrative the problem is political polarization. Hyperpolarized political parties mean that, during unified government, the legislative and executive branches collude and the executive operates with few constraints.

1 Thomas E. Mann \& Norman J. ORnstein, It's Even Worse than It LoOks: How the

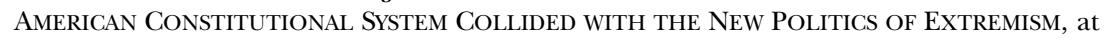
xii-xiv (2012); see also David E. Pozen, Self-Help and the Separation of Powers, 124 YALE L.J. 2, 9 (2014) (describing the "gridlocked, agonistic 'Age of Dysfunction' that we now inhabit”); Jonathan Zasloff, Courts in the Age of Dysfunction, 121 YALE L.J. ONLINE 479, 480 (2012) (collecting sources). 
During divided government, gridlock ensues. ${ }^{2}$ The President and the administrative state fill the vacuum, energetically wielding executive power to partisan ends. ${ }^{3}$ To solve our problems, commentators assert, we must moderate partisanship.

There is a lot of truth to this standard account. But it is not the whole story. If we want to understand our current predicament-and if we hope to have any chance of pulling ourselves out of it-we need to focus not only on partisanship but also on the problem of concentrated wealth and its organization to achieve political ends.

After a period of shared prosperity following the New Deal and World War II, the United States has, over the last generation, experienced a dramatic rise in economic inequality. Disparities in income and wealth are at levels not seen since the Gilded Age. ${ }^{4}$ Rising inequality has been accompanied by the concentration, or reconcentration, of political power among wealthy individuals, large business firms, and organized groups representing them, as well as by a precipitous decline of countervailing organization among middleand low-income Americans. ${ }^{5}$ Organized wealth has overtaken other civic and social organizations as the key driving force in American politics.

Recent scholarly assessment of money in governance has focused on whether it encourages corruption and capture. ${ }^{6}$ But what the literature has almost entirely overlooked is how wealth affects constitutional structure, particularly the separation of powers and the opera-

2 Richard H. Pildes, Why the Center Does Not Hold: The Causes of Hyperpolarized Democracy in America, 99 CAL. L. REV. 273, 333 (2011) (arguing that the consequences of "radically polarized parties" are "unified government without meaningful checks and balances, and divided government that is paralyzed").

3 See, e.g., Bruce Ackerman, The Decline and Fall of the American Republic 120 (2010).

4 See, e.g., Thomas Piketty, Capital in the Twenty-First Century 347-50 (Arthur Goldwater trans., 2014); JOSEPH E. STIGLITZ, THE PRICE OF INEQUALITY, at xxxiv (2013).

5 See, e.g., Lee Drutman, The Business of America is lobbying: How Corporations Became Politicized and Politics Became More Corporate 9-15, 71 (2015); Theda SKoCPOL, Diminished Democracy: From MEMbership to MANAGEMENT IN AMERICAN CIVIC LIFE 128-74 (2003); Martin Gilens \& Benjamin I. Page, Testing Theories of American Politics: Elites, Interest Groups, and Average Citizens, 12 PERSP. ON POL. 564, 576-77 (2014); see also, Nicholas Confessore et al., Small Pool of Rich Donors Dominates Election Giving, N.Y. TIMES (Aug. 1, 2015), http://www.nytimes.com/2015/08/02/us/small-pool-of-richdonors-dominates-election-giving.html ("Fewer than four hundred families are responsible for almost half the money raised in the 2016 presidential campaign, a concentration of political donors that is unprecedented in the modern era.").

6 See, e.g., LaWrence Lessig, Republic, LOST: HOW MONey CORRupts CONGResS-AND A Plan to Stop It 5 (2011); Robert C. Post, Citizens Divided: Campaign Finance REFORM AND THE CONSTITUTION (2014). See also infra notes 150-62, 356. 
tion of checks and balances. ${ }^{7}$ Not in the formal sense of these terms, but in the functional sense: The dominance of organized wealth matters for how power is, or is not, diffused and checked throughout our government; for how ambition does, or does not, counter ambition; and ultimately for the extent of government's democratic responsiveness to the citizenry as a whole, rather than to a particular faction.

Through a range of strategies-from campaign donations, lobbying, and regulatory comment, to the provision of expertise to government officials and the threat of litigation-wealthy individuals, large business firms, and their organizations dominate every step of the political process. The empirical evidence from the social sciences is substantial. ${ }^{8}$ Wealth influences not only Congress and the President, but also the mechanisms scholars argue have replaced Madisonian checks and balances-i.e., political parties and internal executive branch checks.

That is, constitutional law scholars contend that the formal Madisonian schema of separated powers is, to a great extent, anachronistic. The branches qua branches do not have fixed identities or interests that compete. Instead, political competition is channeled in large part through the political parties. ${ }^{9}$ Administrative law scholars agree, though they point to mechanisms within the executive branch that provide an additional or alternative system of checks and balanc-

7 For recent efforts to return questions of economic inequality to constitutional theory, see generally Joseph Fishkin \& William E. Forbath, The Anti-Oligarchy Constitution, 94 B.U. L. Rev. 669 (2014); Bertrall L. Ross II \& Su Li, Measuring Political Power: Suspect Class Determinations and the Poor, 104 CAL. L. REv. (forthcoming 2016); Ganesh Sitaraman, The Puzzling Absence of Economic Power in Constitutional Theory, 101 CORNELL L. REV. (forthcoming 2016). For earlier treatment, see, for example, CHARLES A. BEARD, AN ECONOMIC INTERPRETATION OF THE CONSTITUTION OF THE UNITED STATES 73 (1935) (discussing the economic interests of the Framers of the Constitution); Frank I. Michelman, Foreword: On Protecting the Poor Through the Fourteenth Amendment, 83 HARV. L. REV. 7 (1969).

8 See infra Part II.

9 The leading account is Daryl J. Levinson \& Richard H. Pildes, Separation of Parties, Not Powers, 119 Harv. L. Rev. 2312, 2317-19 (2006). See also Mark Tushnet, The New CONSTITUTIONAL ORDER 8-32 (2003) (describing the influence of political parties in the new constitutional order); Bruce Ackerman, 2006 Oliver Wendell Holmes Lectures: The Living Constitution, 120 HARV. L. REv. 1737, 1809 n.222 (2007) (agreeing with the assertions of Levinson \& Pildes regarding the need for constitutional theory to recognize the centrality of political parties); Bruce Ackerman, The New Separation of Powers, 113 HaRv. L. REv. 633, 644-52 (2000) (noting the influence of politics on controlling key institutions in the American system); cf. Jide O. Nzelibe \& Matthew C. Stephenson, Complementary Constraints: Separation of Powers, Rational Voting, and Constitutional Design, 123 HARV. L. REv. 617, 625, 640 (2010) (examining how separation of powers affects voters' electoral strategies). 
es. ${ }^{10}$ Under this vision of "internal" or "administrative" separation of powers, a multilayered bureaucracy allays fears about the expanded executive, curbs excesses of power even during unified partisan government, and enables continued innovation during divided government. ${ }^{11}$

The "separation of parties" and the "internal" separation of powers accounts do much to ground constitutional theory in practical realities. But they proceed largely without regard to problems of economic and political inequality. This omission stands in contrast to an earlier tradition in constitutional theory. For earlier writers, constitutional structure was not just about the formal separation of powers but also about "the accountability and dispersal of power, broadly construed."12

In our current political moment, questions about the relationship between constitutional structure and the distribution of political and economic power are again urgent. Today, those wielding significant wealth serve almost as a fifth branch of government. ${ }^{13}$ They check and prod the branches, the parties, and the bureaucracy. Because of the weakness of organizations representing ordinary Americans, few countervailing checks exist. The result is that power in government is

10 See, e.g., M. Elizabeth Magill, Beyond Powers and Branches in Separation of Powers Law, 150 U. PA. L. REv. 603, 605-06 (2001) (arguing that rather than powers being split between branches, "government authority is diffused among a large and diverse set of government decisionmakers who have a hand in the exercise of state power"); Gillian E. Metzger, The Interdependent Relationship Between Internal and External Separation of Powers, 59 EMORY L.J. 423, 457 (2009) (emphasizing the role of internal executive branch constraints); Jon D. Michaels, An Enduring, Evolving Separation of Powers, 115 CoLum. L. REv. 515, 532, 536-37 (2015) (discussing the evolution of the balance of power from branches to an administrative theory and beyond).

11 See, e.g., Dawn E. Johnsen, Faithfully Executing the Laws: Internal Legal Constraints on Executive Power, 54 UCLA L. REV. 1559, 1562 (2007) (emphasizing the role of "legal advisors within the executive branch" as a constraint on executive power); Neal Kumar Katyal, Internal Separation of Powers: Checking Today's Most Dangerous Branch from Within, 115 YALE L.J. 2314, 2317-19 (2006) (describing beauracracy as "a critical mechanism to promote internal separation of powers").

12 William J. Novak, Law, Capitalism, and the Liberal State: The Historical Sociology of James Willard Hurst, 18 L. AND HIST. REv. 97, 132 (2000) (discussing the work of James Willard Hurst, the founding father of American legal history); see also infra note 89.

13 The claim is that organized wealth is a fifth branch much in the same way that the media constitutes a fourth estate, see ThOMAS CARLYLE, ON Heroes, Hero-WORSHIP AND THE HEROIC IN History 152 (1840), or the administrate state constitute the fourth branch. See, e.g., FTC v. Ruberoid Co., 343 U.S. 470, 487 (1952) (Jackson, J., dissenting) (declaring that administrative agencies had "become a veritable fourth branch of the Government"); Peter L. Strauss, The Place of Agencies in Government: Separation of Powers and the Fourth Branch, 84 Colum. L. ReV. 573 passim (1984) (describing agencies as a fourth branch). 
both more and less concentrated than the traditional partisanfocused narrative suggests.

Consider, for example, the recent experience with healthcare reform. The standard account posits the exercise of unconstrained executive power in times of unified government. Yet despite a supermajority of Democrats in Congress, the Democratic President was clearly checked. From the outset, it was evident that the President could hold his party in Congress only with the support of industrythe drug industry, the hospital industry, and the insurance industry, among others. The statute that emerged from Congress in 2010, while politically polarizing to this day, represented neither an unbound exercise of partisan power nor an ideological pole of public policy opinion. ${ }^{14}$

Or consider the minimum wage. The standard account is that partisanship explains gridlock on this issue. But substantial bipartisan support for an increase in the minimum wage exists among voters. ${ }^{15}$ The failure of Congress to amend the minimum wage is best explained not by the divide in perspective between Republicans and Democrats, but by the success of organized business interests in ensuring the opposition of key legislators. ${ }^{16}$ Conversely, when Congress recently voted to repeal a restriction on big banks imposed after the 2008 financial crisis, it did so because organized business marshalled bipartisan support. Notably, those Democrats who voted in favor of repeal had received the most money from the financial industry. ${ }^{17}$

As these examples show, partisanship is an incomplete explanation for government's function. The concentration of economic and political power in the hands of the wealthy elite is also a critical factor. To be sure, wealthy interests do not always prevail in politics. Their influence is diminished in high-salience areas and when coun-

14 See infra notes 236-42 and accompanying text.

15 Marianne Levine \& Timothy Noah, Minimum Wage Hikes Win, Politico (Nov. 5, 2014, 1:57 AM), http://www.politico.com/story/2014/11/minimum-wage-increase-wins-in-fourred-states-112565; Constantine Von Hoffman, Support for Raising Minimum Wage Found in Surprising Places, CBS MONEY WATCH (Jan. 28, 2014, 2:32 PM), http:// www.cbsnews.com/news/support-for-minimum-wage-increase-found-in-surprising-places/.

16 See Von Hoffman, supra note 15 ("A December Washington Post poll found two-thirds of Americans support raising the minimum wage, while a recent Gallup poll showed 76 percent in favor.").

17 Philip Bump, Democrats Who Voted for the CRomnibus Have Received Twice as Much Money From the Finance Industry as the "No" Voters, WASH. POST (Dec. 12 2014), http://www. washingtonpost.com/blogs/the-fix/wp/2014/12/12/democrats-who-voted-for-thespending-bill-have-received-twice-as-much-money-from-the-finance-industry-as-the-novoters/. 
tervailing organizations are present and strong. ${ }^{18}$ There are many values and interests other than wealth that play an important role in policy debates. And wealth is not monolithic. Competing views exist among economic elites and organized business interests, as do differences in the mechanisms of participation used by the wealthiest individuals, on the one hand, and business firms and their organizations, on the other. ${ }^{19}$ But together, wealthy individuals and organizations overwhelmingly influence elected officials, the internal bureaucracy, and the political parties in a wide range of arenas. ${ }^{20}$

This systematic influence forces us to reconsider key pillars of the prevailing descriptive account of contemporary executive and legislative power. First, governmental power is systematically more constrained during periods of unified, partisan government than the dominant accounts imply, at least on certain issues. Wealth participates disproportionately at every stage of the democratic process and is well positioned to exploit the system's multiple veto points, providing a strong constraint even during periods of one-party control, and even when a majority of the public supports action. Recent experiences with healthcare, finance, and labor law reform under unified Democratic government illustrate the point. ${ }^{21}$

Second, during periods of divided government, gridlock dominates, but it is not the neutral, cross-substantive phenomenon the dominant theory suggests, nor can it be explained by partisanship alone. Rather, wealth interests affect inaction disproportionately and benefit from it uniquely. This is particularly true of organizations

18 See, e.g., infra notes 142, 158-59, 280-82 and accompanying text.

19 For discussion of who comprises the category of "wealth" or "wealthy interests" and the different ways in which this group engages the political process, see infra notes $81-87$ and accompanying text.

20 While this Article's focus is with the Federal Government, many of its arguments apply with equal force to state governments. In particular, the problem of organized wealth's influence over state judiciaries is particularly acute. See, e.g., BILly CORRIHER, CTR. FOR AM. Progress, KoCH BRothers AND D.C. CONSERVATIVES SPENDING BIG ON NONPARTISAN STATE SUPREME COURT RACES 1-6 (2014), https://cdn.americanprogress.org/wpcontent/uploads/2014/08/StateSupremeCourtsv2.pdf (describing funding of judicial candidates by the Koch brothers and other wealthy donors in order to advance an agenda that includes opposition to redistributive taxes and unions); William Kistner, Justice for Sale?, AMERICAN RADIOWORKS, http://americanradioworks.publicradio.org/ features/judges/ (last visited Oct. 20, 2015) (noting the increasing level of financial contribution to state court elections and the subsequent erosion of judicial independence); Christie Thompson, Trial by Cash, THE ATLANTIC (Dec. 11, 2014), http://www.theatlantic.com/politics/archive/2014/12/trial-by-cash/383631/ (discussing the devolution of judicial races from "largely polite, low-budget affairs" to big-budget, "political circus[es]" in which large campaign donors back judicial candidates in the hopes of garnering votes on the bench).

21 See infra notes 227-55 and accompanying text. 
representing business. As noted, business interests have been able to block changes to labor and employment laws, such as a raise in the minimum wage, even when such changes are overwhelmingly supported in polls. At the same time, during this gridlock, wealthy interests have achieved changes to the status quo through private ordering-such as by increasingly relying on independent contractors who fall beyond the reach of much employment law. ${ }^{22}$

Third, because internal executive branch mechanisms are so often dominated by wealth, they are worse at diffusing power and enabling innovation than their proponents assert. The experience of financial regulatory reform in the aftermath of Dodd-Frank provides just one example of this phenomenon. ${ }^{23}$ In short, wealth both augments and retards the various dynamics of functional checks and balances, and prods and pleas, in ways that are systematic and comprehensive, but not adequately considered by the standard accounts. ${ }^{24}$

Some might contend that the systematic influence of wealth is a boon for the separation of powers' functional aspirations because it moderates and limits government action even in times of unified government. I reject that view. Organized wealth has corrosive effects upon constitutional structure's functional goals-namely, to diffuse political power and ensure ambition counters ambition, in order to promote liberty, governmental efficacy, and democratic accountability. ${ }^{25}$ In particular, wealth's dominance undermines the promise that our system of political checks will produce a government roughly responsive to the majority will. ${ }^{26}$

22 See infra notes 270-73 and accompanying text.

23 See infra notes 284-91 and accompanying text.

24 On the importance of "prods and pleas" as well as "checks and balances" in our system of constitutional governance, see Benjamin Ewing \& Douglas A. Kysar, Prods and Pleas: Limited Government in an Era of Unlimited Harm, 121 YALE L.J. 350, 366-67 (2011).

25 Though this Article engages debates about constitutional aims, it is agnostic on the question of the Founders' original intent. Instead, it adopts the dominant perspective of contemporary constitutional and administrative law theory regarding the functional goals of the separation of powers. See infra notes 58-69, 298-99 and accompanying text.

26 Of course, no government is perfectly responsive to its citizenry and perfect responsiveness may not even be an aspiration of our constitutional system. See generally Adrian Vermeule, The Supreme Court, 2008 Term-Foreword: System Effects and the Constitution, 123 HARV. L. REV. 4, 6 (2009). Still, there is general agreement among theorists that citizens in a democracy ought have equal opportunity to influence the political process, and that government ought to be responsive to their views. See, e.g., Hanna FEnichel Pitkin, ThE CONCEPT OF REPRESENTATION 144-45 (1967); JOHN RAWLS, POLITICAL Liberalism 327 (1993). This Article takes that premise as a given, without trying to articulate an optimal distribution of political power. For a similar approach, see Benjamin I. Sachs, The Unbundled Union: Politics Without Collective Bargaining, 123 YALE L. J. 148, 158 (2013) ("In theory and in doctrine, we can often identify what is troublingly unfair, unequal, or wrong with- 
Where do we go from here? Various possibilities exist to reform the law in response to organized wealth's negative effects on the diffusion of power and democratic accountability. ${ }^{27}$ Much scholarly attention has been focused on reforming voting and campaign finance laws in order to make individual political participation more equal; scholars have also urged making government both more transparent and more insulated from political pressures. ${ }^{28}$ Others advocate heightened judicial scrutiny of laws that harm the poor or benefit organized wealthy interests. ${ }^{29}$ While these proposals are important, the analysis of this Article suggests that their promise has been oversold. Additional, less familiar proposals aimed at involving organizations of citizens in governance and politics are necessary complements. ${ }^{30}$ Consistent with the Madisonian aspiration, reforms aimed at facilitating countervailing organization could help check and balance concentrated power, ensure that ambition counters ambition, and reduce the dominance of one faction. ${ }^{31}$

A final note at the outset: Much of the contemporary literature on capture and corruption refers generally to the problem of "interest groups" and "special interests." ${ }^{22}$ This Article refuses that framing for two reasons. First, the discussion often implicitly or explicitly as-

out a precise standard of what is optimally fair, equal, or right." (quoting Richard H. Pildes, The Theory of Political Competition, 85 VA. L. ReV. 1605, 1612 (1999))).

27 One way to redress the problem of organized wealth in politics and governance is, of course, to enact laws that redistribute wealth through, for example, taxes and transfers, mandates for higher wages, and limits on executive pay. For a sampling of some such proposals, see generally Reuven S. Avi-Yonah, Why Tax the Rich? Efficiency, Equity, and Progressive Taxation, 111 YALE L.J. 1391 (2002); Lucian Arye Bebchuk \& Jesse M. Fried, Executive Compensation as an Agency Problem, 17 J. ECON. PERSP. 71 (2003); Brishen Rogers, Justice at Work: Minimum Wage Laws $\mathcal{E}$ Social Equality, 92 TEx. L. Rev. 1543 (2014). Such proposals are critically important but beyond this paper's focus on the constitutional governance.

28 See infra Part IV.C (evaluting existing reform proposals).

29 See infra Part III.B (evaluating the possibility of heightened judicial scrutiny and noting the influence of wealth on the judiciary).

30 On the role of countervailing power, see generally JOHN KENNETH GALBRAITH, AMERICAN CAPITALISM: THE CONCEPT OF COUNTERVAILING POWER (rev. ed. 1956).

31 See infra Part IV.C. For these purposes, I accept as a given the basic separation-of-powers system. Accord Levinson \& Pildes, supra note 9, at 2348.

32 See, e.g., Michael A. Livermore \& Richard L. Revesz, Regulatory Review, Capture, and Agency Inaction, 101 GEO. L.J. 1337, 1390 (2013) (defining agency capture as "organized groups successfully acting to vindicate their interests through government policy at the expense of the public interest"); Cass R. Sunstein, Interest Groups in American Public Law, 38 STAN. L. REv. 29, 30-31 (1985) (arguing for greater judicial review to weaken the role of "interest groups" and to further republicanism). For a historical perspective on how political economy fell out of discussions about pluralism, see Ira Katznelson, A Lost Opportunity?, in THE Rise AND FALl of THE New DEAL ORder 185, at 192, 204 (Steve Fraser \& Gary Gerstle eds., 1989). 
sumes that participation of organized groups in politics and governance is bad, in part because such participation leads to the incapacity of governmental institutions to serve the public interest. This Article rejects the proposition that participation in government, including through organizations, should be discouraged. "Second, and more importantly, referring to "interest groups" or "special interests" generically obfuscates the distribution of group power. On economic issues, that power is heavily weighted toward business interests and agglomerations of private wealth, and away from the vast majority of Americans. It is this unequal distribution of power that is at the heart of the problems explored in this Article-not the fact of organized participation in democracy.

The Article proceeds as follows. Part I explains why the separation of powers is a useful frame for examining the problem of wealth in governance, even though wealth does not typically function to aggrandize the power of one branch over another.

Part II then uses several strands of social science research, often treated independently from one another, to show that wealth systematically influences existing mechanisms of checks and balances-the branches, the political parties, and the bureaucracy. ${ }^{34}$

Part III revises the prevailing descriptive account of contemporary executive and legislative power. First, it explores how state power is systematically more constrained during periods of unified government than predicted by theorists who focus on partisanship. Second, during periods of divided government, gridlock dominates, but it is not the neutral, cross-substantive phenomenon the dominant accounts suggest. Third, internal executive branch checks often underdeliver on their promise.

Part IV evaluates the influence of wealth against the functional goals of the separation of powers as understood by contemporary scholars. It argues that organized wealth's effects are deleterious, particularly for democratic accountability. It then considers how the

33 For an intellectual history of capture theory, exploring how center-left critiques of the pervasive influence of industry in particular agencies morphed into a neoliberal argument against the general governmental regulatory impulse as a whole, see generally William J. Novak, A Revisionist History of Regulatory Capture, in Preventing Regulatory CAPTURE: SPECial InTERest Influence AND How to Limit IT 25 (Daniel Carpenter \& David A. Moss eds., 2014). See also Thomas W. Merrill, Capture Theory and the Courts: 1967-1983, 72 CHI.-KENT L. REv. 1039, 1055 (1997) (identifying a shift in attitudes toward the administrative state, during the period 1946-1997, from rationalism to populism to libertarianism).

34 The judiciary is considered in Part IV.B. 
law might be reformed in response, arguing for the need to facilitate countervailing organizations.

\section{The Theory and Practice of SeParating, Checking, AND BALANCING POWER}

Public law has long grappled with the fact that certain groups in society have disproportionate power in the democratic political process. $^{35}$ Civil rights scholars address the political and social dominance of whites over blacks, or men over women. Administrative law theorists tackle industry's capture of the regulatory process. Election law scholars worry about the role of wealthy donors and the disenfranchisement of minority voters; they aim to equalize access to the political process, while preventing political corruption.

But the separation of powers has not been a frame for grappling with disproportionate political power. The assumption is that there is no connection between intra-branch interaction in government and the dominance of a particular group in society. This is true to a point. The disproportionate influence of the wealthy (or any other group) would be a problem even if there were only one branch of government. And while wealth consistently checks and prods the branches, it does not necessarily contribute to the aggrandizement of one branch at the expense of another. Rather, wealth operates across the branches. Moreover, it is not at all clear that James Madison or the other Framers intended the system of separated powers to be redistributive in operation, or that they worried about the disproportionate power of economic elites in particular. ${ }^{36}$

35 For suggestions regarding the following points, I am grateful to Daryl Levinson.

36 Some scholars have argued that our system of separated powers and checks and balances, with its multiple veto points and lack of a truly popular lower house, was hard-wired to produce government by the wealthy and propertied classes. BEARD, supra note 7 , at 16568, 324; JeNNIFER Nedelsky, PRIVATE Property AND THE LIMITS OF AMERICAN CONSTitutionalism: THE MAdisOnian FramewORK AND ITS LEGACY 149, 218 (1990). Others counter that although the Founders were concerned about popular tyranny, and advocated checks and balances as one way to limit the masses' power, they were also fundamentally committed to a republican government dependent on the will of the people. Colleen A. SheEhan, James MAdison and the SPIRIT OF RePublican Government 8485 (2009). Indeed, theorists have argued that relative equality among the citizenry (albeit an overly narrow citizenry of white men) was a precondition for the constitutional vision. HANNAH ARENDT, ON REVOlUTION 25 (1965) (arguing that "revolution as we know it in the modern age has always been concerned with both liberation and freedom," and emphasizing equality, among existing citizenry, as a precondition for American constitutionalism). 
Why, then, should we think about wealth's dominance through a structural constitutional lens? For two reasons-and with two important payoffs.

First, bringing wealth's role squarely into structural constitutional theory provides a necessary corrective to the dominant explanations for constitutional dysfunction. ${ }^{37}$ According to commentators across the spectrum, political polarization in Washington has reached crisis levels. ${ }^{38}$ Because of conditions of relatively high interparty polarization and intraparty political fragmentation, Congress is paralyzed in times of divided government; and in periods of unified government, we see legislation that is ideologically ambitious and extreme. ${ }^{39}$ Policy-making is now blood sport, ${ }^{40}$ and rabid partisanship makes political leaders less likely to compromise and less likely to govern wisely in ways responsive to public will. ${ }^{41}$ Americans express deep dissatisfaction with their elected officials. ${ }^{42}$

Hyper-partisanship, legal scholars emphasize, is not just a political problem, it is also a constitutional problem. ${ }^{43}$ As Daryl Levinson and Richard Pildes wrote nearly ten years ago, a system intended to channel competition through the political branches actually channels it through the political parties; in their words, our government is char-

37 See infra Part III (discussing existing structural constitutional law literature's relative silence on subject of wealth in governance and how that results in key descriptive era).

38 See, e.g., Josh Kraushaar, The Most Divided Congress Ever, At Least Until Next Year, NAT'L J. (Feb. 6 2014), http://www.nationaljournal.com/2013-vote-ratings/the-most-dividedcongress-ever-at-least-until-next-year-20140206 (noting that the 2013 congress was the most polarized since polarization has been calculated); see also supra note 1.

39 See Richard H. Pildes, Romanticizing Democracy, Political Fragmentation, and the Decline of American Government, 124 YALE L.J. 804, 808-10 (2014) (arguing that fragmentation of political parties undermines leadership and compromise); Pildes, supra note 2, at 333 (arguing that the consequences of "radically polarized parties" are "unified government without meaningful checks and balances, and divided government that is paralyzed").

40 Thomas O. McGarity, Administrative Law As Blood Sport: Policy Erosion in A Highly Partisan Age, 61 DuKE L.J. 1671, 1679-81 (2012) (identifying partisanship as explanation for "blood sport" policy battles).

41 Pildes, supra note 2, at 330-31; Cass R. Sunstein, Partyism, 2015 U. CHI. LEGAL F. 1, 12-18 (2015); Patricia Wald \& Neil Kinkopf, Putting Separation of Powers into Practice: Reflections on Senator Schumer's Essay, 1 HARV. L. \& POL'y REV. 41, 52 (2007) ("On balance, we find substantial agreement even among these skeptics that things have gotten more polarized and less conducive to good legislating in recent years and that political party domination of Congress is a root cause.").

42 See, e.g., Jeff Zeleny \& Megan Thee-Brenan, New Poll Finds a Deep Distrust of Government, N.Y. Times, Oct. 26, 2011, at A1 ("Not only do 89 percent of Americans say they distrust government to do the right thing, but 74 percent say the country is on the wrong track and 84 percent disapprove of Congress-warnings for Democrats and Republicans alike.").

43 Levinson \& Pildes, supra note 9, at 2313. 
acterized by the "separation of parties, not powers." And because of hyper-polarization, the system breaks down. According to some commentators, the executive branch during unified government is dangerously unchecked; during divided government, it inappropriately pushes the bounds of formal authority to advance a political agenda. ${ }^{45}$ Other scholars are more sanguine: They acknowledge the role of partisanship but point to mechanisms within the executive branch that curb excesses of power, while enabling continued innovation. ${ }^{46}$

The partisanship diagnosis for the affliction of constitutional dysfunction is pervasive-and has had profound impact on legal scholarship. ${ }^{47}$ It has served as the basis for a host of descriptive arguments regarding administrative law, ${ }^{48}$ separation of powers, ${ }^{49}$ and federal-

$44 \quad I d$.

45 See supra notes $2-3$ and accompanying text.

46 See supra notes 10-11 and accompanying text.

47 On the influence of the partisanship theory, see Ackerman, supra note 9, at 1810 n.222 (describing the parties-not-powers theory as a "breakthrough" and an "essential reference point"); Richard A. Epstein, Why Parties and Powers Both Matter: A Separationist Response to Levinson and Pildes, 119 HARV. L. REV. F. 210, 210 (2006) (describing the Levinson-Pildes theory as "provocative and instructive"); Mark Tushnet, Constitutional Workarounds, 87 TEX. L. REV. 1499, 1512 (2009) (describing as "relatively widespread," the "understanding that the working U.S. Constitution depends heavily on the operation of the political party system").

48 David J. Barron \& Todd D. Rakoff, In Defense of Big Waiver, 113 ColuM. L. REV. 265, 267, 306 (2013) (noting that hyper-partisanship and divided government have contributed to a new form of congressional delegation of broad lawmaking power to administrative agencies, which has come to define the modern regulatory state); Neal Devins \& David E. Lewis, Not-So Independent Agencies: Party Polarization and the Limits of Institutional Design, 88 B.U. L. REV. 459, 479, 498 (2008) (noting that "the separation of powers between Congress and the White House has given way to the "separation of parties"' and using that theory to understand the operation of independent agencies); Jody Freeman \& David B. Spence, Old Statutes, New Problems, 163 U. PA. L. REV 1, 1-5 (2014) (arguing that because of the influence of partisanship on inter-branch relations, Congress is increasingly absent from the policymaking process, and fails to regularly update statutes in the face of social, economic, and technological change; this leaves agencies to adapt old statutes to new problems); McGarity, supra note 40, at 1762 (identifying partisanship as the explanation for policy failure in the regulatory state).

49 See, e.g., David Fontana, Government in Opposition, 119 YALE. L.J. 548, 602-03 (2009) (explaining that the vision of branch loyalty upon which the American originalist vision of a separation of powers is based has collapsed and arguing for government in opposition rules to better constrain unified government); Katyal, supra note 11, at 2321 ("This expansion of presidential power is reinforced by the party system. When the political branches are controlled by the same party, loyalty, discipline, and self-interest generally preclude interbranch checking."); William P. Marshall, Eleven Reasons Why Presidential Power Inevitably Expands and Why It Matters, 88 B.U. L. REV. 505, 519 (2008) ("The problem, of course, is that separation of parties serves as no balance at all when both the Presidency and the Congress are controlled by the same party. In those circumstances, the power of the Presidency is effectively unchecked.”). 
ism. ${ }^{50}$ For example, scholars invoke polarization to explain the rise of executive power, ${ }^{51}$ including recent innovations of the administrative state, ${ }^{52}$ and to analyze the impotence of Congress. ${ }^{53}$ They also point to partisanship when exploring the relevance of historical acquiescence between the branches ${ }^{54}$ and the nature of contestation, or the lack thereof, on the state-federal dimension. ${ }^{55}$ Concerns about partisanship motivate numerous reform proposals: Legal scholars have explored how partisanship might be moderated and how internal executive branch innovations can mediate government dysfunction resulting from hyper-polarization, either by providing a check on the partisan executive from within or by enabling policy innovation in an era of gridlock. ${ }^{56}$

The conclusion that partisanship is a driving force in government, causing both legislative gridlock and instances of executive overreach, is unassailable. A look at recent headlines coming out of Washington proves the point. Yet the preoccupation with partisanship has obscured another important force in contemporary constitutional governance-wealth.

Wealth and partisanship are not unrelated. Indeed, rising inequality, political scientists argue, is one important cause of hyperpolarization. ${ }^{57}$ At the same time, as Parts II and III show, wealth's influence cuts across partisan divides, narrowing the divergence between party elites on key issues; it also affects the internal executive branch mechanisms scholars celebrate as a check on partisanship. In

50 See Jessica Bulman-Pozen, Partisan Federalism, 127 HARV. L. REv. 1077, 1078 (2014) (positing that partisanship, rather than something essential to our federal structure, explains why states check the Federal Government and whether Americans identify with the states as well as the nation).

51 See Marshall, supra note 49, at 518-19 ("[I]n an era of highly polarized parties, there no longer exists the constitutional balance purportedly fostered by separation of powers.”).

52 See Freeman \& Spence, supra note 48, at 79-81 (describing the recent efforts of administrative agencies to revitalize old statutes to accomplish new policy objectives in the wake of congressional inaction).

53 See Elena Kagan, Presidential Administration, 114 Harv. L. Rev. 2245, 2311 (2001) (“[T]he possibility of significant legislative accomplishment ... has grown dim in an era of divided government with high polarization ...."); cf. Levinson \& Pildes, supra note 9, at 2344 (asserting that electoral accountability is least effective "when party control of government is divided").

54 See Curtis A. Bradley \& Trevor W. Morrison, Historical Gloss and the Separation of Powers, 126 HARV. L. REV. 411, 413-15 (2012) (positing that arguments about historical acquiescence often rest on assumptions about congressional-executive relations that do not reflect actual institutional behavior, in part because of partisanship); Julian Davis Mortenson, Executive Power and the Discipline of History, 78 U. CHI. L. REv. 377, 412-17 (2011).

55 Bulman-Pozen, supra note 50, at 1078.

56 See supra note 11; see also infra note 350.

57 See infra note 178 and accompanying text. 
short, we cannot understand how contemporary mechanisms of political competition function without examining wealth's effect on them. And only by viewing the dynamics of wealth in governance holistically, rather than as isolated problems of campaign money and agency capture, as the legal literature tends to do, does a more complete picture of constitutional function and dysfunction emerge.

The second reason why the separation of powers is a useful frame is that the problem of wealth's dominance in governance is analogous in important respects to the problems Madison and the other Framers hoped to tackle when constituting the government. The first three Articles of the United States Constitution are designed to create a framework for democratic governance. They aim to guard against two broad classes of political pathology, both involving the dominance of one group over another. ${ }^{58}$ First, the Framers were concerned about protecting citizens who might be tyrannized by despotic and corrupt federal officials. " "In framing a government which is to be administered by men over men," Madison wrote in Federalist No. 51, "the great difficulty lies in" obliging the government "to control itself." 60 Second, the Framers worried about factions of the electorate seeking to capture government for their own selfish ends. ${ }^{61}$ Thus, Federalist No. 51 continues, " $\mathrm{i}] \mathrm{t}$ is of great importance in a republic not only to guard the society against the oppression of its rulers, but to guard one part of the society against the injustice of the other part." 62

Madison understood the dangers of faction to inhere in both the majority and the minority, but he was far more worried about the tyranny of the majority. ${ }^{63}$ He failed to predict, or perhaps did not fear, the extent to which a small elite would come to dominate. ${ }^{64}$

58 Daryl J. Levinson, Parchment and Politics: The Positive Puzzle of Constitutional Commitment, 124 Harv. L. Rev. 657, 666 (2011) [hereinafter Parchment and Politics]; Daryl J. Levinson, Rights and Votes, 121 YALE L.J. 1286, 1293 (2012).

59 Levinson, Parchment and Politics, supra note 58, at 666.

60 The Federalist No. 51, at 322 (James Madison) (Clinton Rossiter ed., 1961).

61 Levinson, Parchment and Politics, supra note 58, at 666 (citing The Federalist No. 10, AkHil Reed Amar, The Bill of Rights: Creation and Reconstruction at xii-xiii (1998)).

62 THe FEDERAList No. 51, supra note 60, at 322.

63 Compare The Federalist No. 10, supra note 60, at 78 (James Madison) ("By a faction I understand a number of citizens whether amounting to a majority or minority of the whole, who are united and actuated by some common impulse of passion, or of interest, adverse to the rights of other citizens, or to the permanent and aggregate interests of the community."), with THE FEDERALIST NO. 51, supra note 60, at 323 ("If a majority be united by a common interest, the rights of the minority will be insecure."). See also Levinson, Rights and Votes, supra note 58, at 1294.

64 See supra note 36 and accompanying text. 
Nevertheless, the overarching concern of Madison and the other Framers was with a government in service of a particular faction, rather than the general good; their object was to prevent a government that put the interests of the minority or the majority above "the rights of other citizens" and "the permanent and aggregate interests of the community." ${ }^{\prime 65}$

Rather than attempting to enumerate the rights of the majority and minority and protect them directly, as the Bill of Rights, the Reconstruction Amendments, and much contemporary public law tries to do, Madison and the other Framers hoped the structure of government would guard against corrupt officials and powerful factions indirectly. ${ }^{66}$ They sought to shift power to the national government in the hope that more factions would be brought into competition with one another, thereby making it more difficult for one faction to capture the government. ${ }^{67}$ They created branches and levels of government, in the hope that the different branches would compete with one another, creating a self-enforcing check on national officials. ${ }^{68}$ In short, they hoped to create a government in which "[a]mbition" would "counteract ambition." 69

This system of "checks and balances" and "separated powers" has analogues in other constitutional systems, present and historical. Consider, for example the theory of mixed government. That tradition, with its ancient pedigree, is based on the belief "that the major interests in society must be allowed to take part jointly in the functions of government, so preventing any one interest from being able to impose its will upon the others." ${ }^{70}$ For the British contemporaries (and predecessors) of the Framers, mixed government was about balancing the rights of the King, the Lords, and the Commons, and preventing any one class from dominating the others. ${ }^{71}$ For the Framers, economic class was less central. ${ }^{72}$ But the approach incorporated

\footnotetext{
The Federalist No. 10, supra note 60, at 78.

66 See Levinson, Rights and Votes, supra note 58, at 1295 (discussing Framers' structural approach). M.J.C. Vile writes, the separation of powers "assumes that the legislature will, or may, be taken over entirely by the democratic element, and that checks upon 'mob rule' will therefore have to be applied by branches of the government largely or wholly outside the legislature." Id. at 37. See also supra note 36.
} 
many of mixed government's concepts. ${ }^{73}$ The premise remained that allocating political decisionmaking power would be a more reliable way to guard against the problems of factional dominance than express prohibitions on, or guarantees of, particular political outcomes.

The theory and practice of "consociational democracy" provides another analogy. ${ }^{75}$ That model "institutionalizes power-sharing among [groups in society] through arrangements like grand coalition cabinets, proportional representation in the legislatures, and mutual veto rights." ${ }^{76}$ Other societies have adopted different structural approaches to balance power in the face of deep social divides. ${ }^{77}$ At the sub constitutional level, a parallel can be found in the practice of "corporatism" - the system of institutionalizing representation of social groups, such as unions, business associations, and professional groups, into decisionmaking boards to which significant authority is delegated by government. ${ }^{78}$ But all of these systems share the basic approach of avoiding the dominance of one group over others through organizational and structural mechanisms. ${ }^{79}$

By viewing the problem of wealth in governance through the lens of structure and power sharing, an array of reform options that are often missing from the rights-centric approach predominant in American public law comes into focus. ${ }^{80}$

73 For two accounts of the theory of mixed government and its relationship to separation of powers, see W.B. GWYn, The Meaning of the Separation of Powers: An of the DOCTRINE From ItS ORIGIN TO THE ADOPTION OF THE UNITED STATES CONSTITUTION (1965); VILE, supra note 70.

74 See Levinson, Rights and Votes, supra note 58, at 1293-1300 (discussing, in addition to the Madisonian approach, John C. Calhoun's proposal for a dual executive comprising a Northern and Southern President, as well as suggestions for balancing the Supreme Court between Justices from slaveholding and non-slaveholding states).

75 Id. at 1307-11. The leading theorist is Arend Lijphart. See generally AREND LiJPHART, DEMOCRACY IN PluRAl SOCIETIES: A COMPARATIVE EXPLORATION (1977) (arguing that a system of consociational democracy can help produce stability in plural societies); Arend Lijphart, Consociational Democracy, 21 WORLD POL. 207 (1969) (explaining the concept of consociational democracy).

76 Levinson, Rights and Votes, supra note 58, at 1307-08.

77 Id. at 1308-10.

78 See Peter A. Gourevitch, The Politics of Corporate Governance Regulation, 112 YALE L.J. 1829, 1869 (2003) (reviewing MARK J. ROE, POlitical Determinants of Corporate GOVERNANCE: POLITICAL CONTEXT, CORPORATE IMPACT (2003)) (defining corporatism).

79 Levinson, Rights and Votes, supra note 58, at 1307-08.

80 See Part IV.C. Such reforms do not require abandonment of our basic constitutional structure, but rather can be adopted within the existing regime as complements to traditional reform strategies. 


\section{THE POWER OF ORGANIZED WEALTH}

Before proceeding, it is important to define the category "wealth" or "wealthy interests" - and to acknowledge the challenge of doing so. I use the term to refer to wealthy individuals-those who comprise the top $1 \%$ and $.01 \%$ of income earners and wealth holders and those in the top socieoeconomic status ("SES") quintile-as well as to large business organizations, particularly corporations and their trade associations. There is considerable overlap among and between these two groups. The country's wealthiest individuals are, for the most part, the leaders, owners, and directors of the wealthiest business organizations. $^{81}$

But there are also important differences between economic elites and wealthy business organizations. For one, individuals and organizations tend to participate in the governance process in different ways. Organizations focus more energy on lobbying and on the regulatory process, while wealthy individuals tend to concentrate more on campaign contributions. ${ }^{82}$ Individuals tend to be more partisan and ideological in their giving patterns, while businesses tend to donate to both political parties strategically. ${ }^{83}$

Meanwhile, among wealthy individuals and business organizations, there are competing views and preferences. For example, when acting individually, economic elites tend to prefer lower government spending across the board, but when operating within a particular business organization, they tend to favor more spending on that particular industry's subsidies. ${ }^{84}$ Moreover, business groups and wealthy individuals are not always in agreement with one another. Sometimes there is vigorous lobbying on multiple sides of an issue. ${ }^{85}$

81 See, e.g., Nicholas Confessore et al., Small Pool of Rich Donors Dominates Election Giving, N.Y. TiMES (Aug. 1, 2015), http://www.nytimes.com/2015/08/02/us/small-pool-of-richdonors-dominates-election-giving.html ("Fewer than four hundred familes are responsible for almost half the money raised in the 2016 presidential campaign . . .."); MillionDollar Donors in the 2016 Presidential Race, N.Y. TIMES, http://www.nytimes.com/ interactive/2016/us/elections/top-presidential-donors-campaign-money.html (last updated Aug. 25, 2015) (identifying donors who have contributed more than a million dollars to the 2016 presidential campaigns and listing their occupations).

82 See Edward T. Walker \& Christopher M. Rea, The Mobilization of Firms and Industries, 40 ANN. REv. SoC. 281, 286 (2014) (noting that "[t]he largest share of PAC money comes from individuals" and that "corporate PAC spending is only a fraction of what firms tend to spend on lobbying").

83 Gilens \& Page, supra note 5, at 571; see also infra notes 186-87 and accompanying text.

Gilens \& Page, supra note 5, at 571.

See, e.g., Joshua Brustein, Behind Closed Doors, Ford, UPS, and Visa Push for Net Neutrality, BLOOMBERG BUSINESS (Nov. 14, 2014), http://www.bloomberg.com/bw/articles/2014-1114/net-neutrality-ford-ups-visa-and-bofa-lobby-fcc-in-secret (describing how Internet ser- 
Yet recent studies suggest that divergence of opinion on economic issues among wealthy individuals is less common than one might expect. $^{86}$ And while business groups diverge on discrete issues, e.g., to lobby for their own industry's interest, they, like wealthy individuals, are generally unified on broad principles of economic policy, including tax policy, labor policy, and deregulation. ${ }^{87}$ In short, as the following sections will elaborate, the category of wealth, while not homogenous, is coherent. And, though not always decisive, wealthy interests collectively serve as a systematic check and prod on the political branches, the political parties, and on the administrative state, fundamentally shaping their interactions. ${ }^{88}$

\section{A. Organized Wealth in Politics}

Concern about the relationship between wealth and democracy is not a new feature of American political discussion. ${ }^{89}$ But it is now, once again, at the center of public debate. One can easily theorize why: After a period of relative shared prosperity following the New Deal and World War II, income inequality has returned to pre-New Deal levels. ${ }^{90}$ The data from economists are striking. Since the 1970s,

vice providers have been pushing the F.C.C. for looser regulation of broadband access, while technology startups, joined by "a corporate alliance with subtle interests in [the regulatory] fight," has been lobbying for more muscular regulation); Peggy Lowe, Hundreds of Lobbying Interests Influenced the Farm Bill, NETNEBRASKA.ORG (Jul. 14, 2014, 6:30 AM), http://netnebraska.org/article/news/927265/hundreds-lobbying-interestsinfluenced-farm-bill (noting that food companies and energy interest lobbies were on opposing sides in the 2014 Farm Bill debate over ethanol production); Amy Schatz, Google, Wireless Industry Not Down With Marriott's Wi-Fi Blocking Plan, RE/CODE (Dec. 22, 2014, 12:31 PM), http://on.recode.net/1zcxv0y (describing how Google, Microsoft, and the wireless industry are opposing the hotel industry's efforts to gain the F.C.C.'s permission to block personal Wi-Fi networks on their properties).

86 Gilens \& Page, supra note 5, at 571

87 Id. at 571,575 .

88 The impact of money on the third branch, the judiciary, is also substantial, as discussed in Part IV.B.

89 See, e.g., Eric Foner, Tom Paine And Revolutionary America, 132-35 (1976) (noting that the penultimate draft of the Declaration of Rights that began Pennsylvania's constitution warned that excessive accumulation of land or wealth is "dangerous to the Rights, and destructive of the Common Happiness" of the community); CHARLES EDWARD Lindblom, Politics ANd Markets: The WORLd's Political ECONOMic SYSTEMs 171 (1977) (arguing that the political power of large private corporations undermines democratic responsiveness to any other interest in society). For a discussion of these sources and the broader constitutional dimension of debates about oligarchy and democracy, see generally Joseph Fishkin \& William E. Forbath, Wealth, Commonwealth, E् The Constitution of Opportunity: A Story of Two Traditions, NOMOS (forthcoming 2015), http:// papers.ssrn.com/sol3/papers.cfm?abstract_id=2620920.

90 PIKETTY, supra note 4, at 20-27; see also Jacob S. Hacker \& Paul Pierson, Winner Take-All Politics: Public Policy, Political Organization, and the Precipitous Rise of Top Incomes in the Unit- 
incomes of the poor and middle class have stagnated, while the overall economy has expanded and the wealthy, particularly those at the very top, have become even wealthier. ${ }^{91}$ Notably, the shift of resources has been sustained, with both income and wealth inequality increasing steadily since around $1980 .{ }^{92}$ The trend is not obviously related to either the business cycle or to control by a particular party in Washington. ${ }^{93}$

As economic inequality has soared, so too has political inequality. Putting aside, for the moment, the normative question of whether dominance of the wealthy in politics and governance is problematic

ed States, 38 POL. \& SOC'Y 152, 155 (2010) ("That income inequality has grown substantially over the past thirty years is no longer in dispute."). For a description of the literature documenting the growth of economic inequality, see KAY LEHMAN SCHLOZMAN ET AL., The Unheavenly Chorus: Unequal Political Voice and the Broken Promise of AMERICAN DEMOCRACY, $71 \mathrm{n.5}$ (2012). While inequality is a problem in other nations as well, the United States ranks far worse than most of its peers. The United States has one of the highest levels of inequality, as measured by the Gini coefficient before taxes and transfers, among the members of the Organization for Economic Cooperation and Development ("OECD"). Timothy M. Smeeding, Public Policy, Economic Inequality, and Poverty: The United States in Comparative Perspective, 86 Soc. SCI. Q. 955, 958, 962 (2005). When government taxes and benefits are taken into account, American inequality is comparatively even greater. Id. at 961-63; SCHLOZMAN ET AL., supra, at 77-78. Furthermore, while our tax and transfer system is still progressive, it has grown less so over time. According to the CBO comprehensive income data, since 1979, inequality rose twentythree percent before taxes and transfers and thirty percent after. Notwithstanding some significant progressive innovations, like the EITC, taxes and transfers are less effective at ameliorating inequality now than they were in 1979. See Jared Bernstein, Why Christie's Adviser is Wrong on Economic Inequality, THE STAR-LEDGER (Jan. 5, 2014, 7:47 AM), http://blog.nj.com/njv_guest_blog/2014/01/why_gov_chris_christies_advise.html.

91 The most comprehensive data on income inequality comes from economists Thomas Piketty and Emmanuel Saez. See generally Thomas Piketty \& Emmanual Saez, Income Inequality in the United States, 1913-1998, 118 Q.J. ECON. 1 (2003). For updated tables and figures for 2014, see http://eml.berkeley.edu/ saez/TabFig2014prel.xls). On wealth inequality, see Kevin Phillips, Wealth and Democracy: A Political History of the AMERICAN RICH 122-23 (2002) (illustrating that $40 \%$ of assets and $12-20 \%$ of U.S. income is controlled by the top $1 \%$ of the American population); SCHLOZMAN ET AL., supra note 90 , at 75-76 (articulating that wealth has always been more unevenly divided than either earnings or household income). On increasing productivity and work hours during the period of economic stagnation, see Jared Bernstein \& Karen Kornbluh, Running Faster to Stay in Place: The Growth of Family Work Hours and Incomes, NeW AM. FOUND. WORK AND FAMILY PROGRAM (2005). A recent study predicts that by 2016, the richest one percent is likely to control more than half of global wealth. Deborah HaRdoOn, Wealth: HAVING It ALL AND WANTING MORE, OXFAM 2 (January 2015), http://www.oxfam.org/en/research/wealth-having-it-all-and-wanting-more.

92 Picketty \& Saez, supra note 91 , at 17.

93 Hacker \& Pierson, supra note 90, at 156; cf. NOLAN MCCARTY ET AL., POLARIZED AMERICA: THE DANCE OF IDEOLOGY \& UNEQUAL RICHES 2 (2006) (arguing that rising partisanship helps produce economic inequality). For further discussion of the relationship between wealth concentration and partisan control, see infra Part II.C. 
and why ${ }^{94}$ the evidence of such dominance is substantial. Consider first the disparate participation of economic elites as individuals. At every stage of the electoral and governing process, wealthy Americans-those in the top SES quintile-participate at higher levels than their lower-income counterparts. ${ }^{95}$ They vote at higher rates, they contribute more frequently and in greater amounts to campaigns, they volunteer more frequently on political campaigns, and they are more likely to contact a representative about an issue. ${ }^{96}$ The gap between wealthy Americans' participation in politics and that of other Americans, which narrowed in the post-New Deal period, has widened in recent years, particularly as expressed by campaign donations. For example, just three decades ago, the top $.01 \%$ gave about $10 \%$ of all campaign contributions; now they are responsible for $40 \%{ }^{97}$ As top incomes have increased exponentially, the wealthy have had more money to spend on electoral politics. ${ }^{98}$ Meanwhile, a series of recent decisions from the Supreme Court has made it easier for the wealthy to contribute greater sums of money and to do so anonymously. $^{99}$ In addition, wealthy individuals are, and have always

94 See infra Part IV.A.

95 The average amount of political activity rises steeply across five quintiles of SES. SCHLOZMAN ET AL., supra note 90, at 6-8, 14; see also id. at 122, 122 n.8, 136, 169, 197 (demonstrating that the higher the SES quintile to which a person belongs, the more likely he or she is to vote, contribute money to a campaign, engage in political discussion daily, be more persistently politically active over time, and to have come from a politically engaged family).

96 SCHLOZMAN ET AL., supra note 90, at 136.

97 Adam Bonica et al., Why Hasn't Democracy Slowed Rising Inequality?, 27 J. Econ. PERSPECTIVES 103, 111-12 (2013).

98 SChlozman ET AL., supra note 90, at 175. Indeed, more money was spent in the 2012 election than ever before: federal candidates and independent supporters spent more than $\$ 6$ billion on campaigns. Nicholas Carnes, Who Votes for Inequality?, (unpublished manuscript) (manuscript at 9), http://people.duke.edu/ nwc8/Carnes_Who_Votes_for_ Inequality.pdf ("In the House, the average incumbent raised $\$ 1.2$ million; in the Senate, incumbents raised roughly $\$ 11$ million each.”); see also DAVID CALlaHAN \& J. MIJIN CHA, Stacked Deck: How the Dominance of Politics by the AFFluent \& Business UNDERMINES ECONOMIC MOBILITY IN AMERICA 1 (2013), http://www.demos. org/sites/default/files/imce/StackedDeck_1.pdf. (noting the disparity between the participation of the affluent compared to less wealthy Americans).

99 See, e.g., McCutcheon v. Fed. Election Comm'n, 134 S. Ct. 1434, 1441 (2014) (“[W]e have made clear that congress may not regulate contributions simply to reduce the amount of money in politics, or to restrict the political participation of some in order to enhance the relative influence of others."); Citizens United v. Fed. Election Comm'n, 558 U.S. 310, 371-72 (2010) (holding that corporations have a First Amendment right to spend money to support or denounce candidates in elections); Davis v. Fed. Election Comm'n, 554 U.S. 724, 741 (2008) (striking down regulation that sought to balance spending against selffunded millionaires). Election spending has spiked since these decisions. See Seth Masket, Are the Super-Wealthy Buying Democracy?, Mischiefs OF FACTION (May 16, 2014), http://www.mischiefsoffaction.com/2014/05/are-super-wealthy-buying-democracy.html 
been, far more likely to serve as elected and appointed leaders than are lower-income Americans. ${ }^{100}$

However, the extent to which wealth dominates our system of governance only becomes clear when we shift focus from the individual to the collective-or, in Madisonian terms, to the level of faction. Two important points: First, individuals in the top SES quintile participate in organized political groups at substantially higher rates than other Americans, ${ }^{101}$ across every domain of organized interest activity. ${ }^{102}$ As social scientists have explored, the affluent are better able to afford the financial costs of organization, and to command the skills, acquire the information, and cultivate the media necessary to keep organizations running. ${ }^{103}$

Second, and more important, business organizations overwhelmingly dominate political activity in Washington. The majority of politically engaged groups in Washington are organized around economic goals and interests, and of such groups, those representing business constitute more than two-thirds. ${ }^{104}$ More than three-quarters of money reportedly spent on lobbying goes toward representing corporate America-a total of $\$ 2.57$ billion in $2012 .{ }^{105}$ And "there is good reason to believe that [these numbers] significantly undercount the true

(demonstrating a spike in contributions following the Supreme Court's decision in Citizens United).

100 Millionaires make up only $3 \%$ of the population, but they have a majority in the House of Representatives and a filibuster-proof super-majority in the Senate. At the same time, people with manual labor and service industry jobs have made up more than half of the population since the start of the twentieth century, yet people from such backgrounds have never held more than $2 \%$ of the seats in Congress. NiCHOLAS CARNES, WHITE Collar Government: The Hidden Role of Class in Economic Policy Making 7 (2013). For more discussion on this subject, see Russ Choma, Millionaire's Club: For First Time, Most Lawmakers are Worth \$1 Million-Plus, OpenSecrets BlOG (Jan. 9, 2014), http://www.opensecrets.org/news/2014/01/millionaires-club-for-first-time-mostlawmakers-are-worth-1-million-plus/ (noting that for more than half of Congress are millionaries); Stephen Lurie, Why It Matters That Politicians Have No Experience of Poverty, THE ATLANTIC (June 2, 2014), http://www.theatlantic.com/politics/archive/2014/06/why-itmatters-that-politicians-have-no-experience-of-poverty/371857/ (pointing out that nearly 200 members of Congress are multimillionares).

101 SCHLOZMAN ET AL., supra note 90, at 276.

102 Id. at 320

103 For discussion of why the wealthy are better able to organize, see $i d$. at 313; E.E. Schattschneider, The Semisovereign PeOple: A Realist's VieW of Democracy in AMERICA 35 (1960).

104 See SCHLOZMAn ET AL., supra note 90, at 320, 322 (noting that "[m] ore than two-thirds of the organized interests in Washington are institutions or membership associations directly related to the joint political concerns that arise from economic roles and interests" and those representing business constitute more than three quarters of these). 
corporate investments in politics, given that so much political influence activity is not covered by lobbying disclosures." 106

While business has always been engaged in politics, organizations representing business interests have proliferated and expanded their collective capacity over the last forty years. ${ }^{107}$ Very few companies, prior to the 1970s, had their own lobbyists; even at the trade association level, political engagement was limited by contemporary standards. ${ }^{108}$ With each passing year, corporate America has spent more on lobbying and has expanded its political operations. ${ }^{109}$ Today, large corporations have achieved "a pervasive position that is unprecedented in American political history." 110 Moreover, according to some theorists, as businesses assumed this dominant position in Washington, their ideological cast also changed: The more "moderate" and public-minded manufacturing-based businesses of the 1950s were replaced by more conservative and narrowly focused financial organizations. ${ }^{11}$

The participation in politics and governance by business organizations dwarfs participation by other interests ${ }^{112}$ : Business groups and their trade associations both far outnumber and far outspend organizations representing working and poor Americans and diffuse public interest groups. ${ }^{113}$ Indeed, while business organizations have become

$106 I d$. at 9 .

107 Hacker \& Pierson, supra note 90, at 177. The Chamber of Commerce, for example, doubled in membership between 1974 and 1980, as did the National Federation of Independent Business. The Business Roundtable, designed to mobilize high-level CEOs for the advancement of shared interests, formed in 1972, and has been active since. Id. at 176. In addition, " $[\mathrm{t}]$ he number of corporations with public affairs offices in Washington grew from 100 in 1968 to over 500 in 1978. In 1971, only 175 firms had registered lobbyists in Washington, but by 1982, 2,445 did. The number of corporate PACs increased from under 300 in 1976 to over 1,200 by the middle of 1980." Id. While small businesses figure prominently in political rhetoric, representatives of large businesses dominate in Washington. See John M. de Figueiredo \& Brian Kelleher Richter, Advancing the Empirical Research on Lobbying, 17 ANN. REV. POL. SCI. 163, 165-66 (2014) (arguing small businesses are less likely to lobby for interests compared to large businesses). DRUTMAN, supra note 5, at 9, 55-71.

$I d$.

$110 \quad I d$. at 1.

111 See generally Mark S. Mizruchi, The Fracturing of the American Corporate Elite (2013) (comparing the corporate elite of today's world with the corporate elite of the post World War II industrial world).

112 See SChlozman ET AL., supra note 90, at 439 (noting that participation via amicus briefs in litigation is one exception).

113 DRUTMAN, supra note 5, at 9. One study found "that 72 percent of expenditures on lobbying originate with organizations representing business." SCHLOZMAN ET AL., supra note 90, at 442. Another concluded that "[1] obbying expenditures by corporations and trade associations represent over $84 \%$ of total interest group lobbying expenditures at the U.S. federal level...." de Figueiredo \& Richter, supra note 107, at 165. A single business 
both more prevalent and more sophisticated in their political activity, countervailing organizations have atrophied. "At various points in American history [public interest groups and unions] served as meaningful political counterweights to corporations."

Beginning in the 1960s, and accelerating in subsequent decades, membership organizations of ordinary Americans built in the Progressive and New Deal Eras declined in number and scope. ${ }^{115}$ That is not to say that non-business groups altogether disappeared from the landscape. In fact, the 1960 s and 70 s saw the founding of numerous public interest organizations, along with the rise of transformative social movements. But for the most part, the organizations that endured past the 1980s were professionally managed advocacy groups, dominated by the elite. Today, less than a third of the organizational advocates operating in Washington are membership associations of any kind, and only about an eighth are membership associations of individuals. ${ }^{116}$ Thus, even the comparatively few organizations purporting to represent the public interest are dominated by the wealthy and funded primarily by large donors. Gone are the days when cross sections of Americans participated in governance decisions through their representative organizations. ${ }^{117}$

Unions are one notable exception; their membership and funding is still drawn from working Americans. And unions have continued to participate at every level of politics and government, often provid-

group, the U.S. Chamber of Commerce, spent \$1.166 billion lobbying the federal government between 1998 and 2014, compared to $\$ 628$ million by all labor unions combined. Ctr. for Responsive Politics, Lobbying Spending Database-Top Spenders 1998-2015, OPENSECRETS.ORG, $\quad$ https://www.opensecrets.org/lobby/top.php?showYear=a\& indexType=s (last visited Oct. 9, 2015); Ctr. for Responsive Politics, Lobbying Spending Database-Labor, OPENSECRETS.ORG, https://www.opensecrets.org/lobby/indus.php? id= $\mathrm{P} \&$ year=a (last visited Oct. 9, 2015). The top three healthcare industry groups spent more than three times as much on lobbying during this period as AARP. Ctr. for Responsive Politics, Lobbying Spending Database-Top Spenders 1998-2015, OPENSECRETS.ORG, https://www.opensecrets.org/lobby/top.php?showYear=a\&indexType=s (last visited Oct. 9, 2015); Center for Responsive Politics, Lobbying Spending Database-AARP, OPENSECRETS.ORG, $\quad$ https://www.opensecrets.org/lobby/clientsum.php?id= D000023726\&year=2014 (last visited Oct. 9, 2015).

114 DRUTMAN, supra note 5, at 9-10.

115 See SKOCPOL, supra note 5, at 135-38 (discussing the origins of the civil rights movement, the feminist movement, and the modern environmental movement and the simultaneous decline of membership organizations). See also Robert Putnam, Bowling Alone: The COLLAPSE AND REVIVAL OF AMERICAN COMMUNITY 27 (2000) (arguing that Americans have been increasingly disconnected from one another).

116 SCHLOZMAN ET AL., supra note 90, at 319.

117 Kate Andrias, Hollowed-Out Democracy, 89 N.Y.U. L.J. OnLINE 48, 50 (2014). For a discussion of how these trends affect political parties, see infra Part II.C. 
ing a countervailing voice to organized business groups. ${ }^{118}$ Since the 1970s, however, the labor movement's size and power has shrunk considerably. ${ }^{119}$ Meanwhile, over the last decades, labor unions have often focused more on their own members' immediate interests than on broad-based political goals. ${ }^{120}$

In short, countervailing organizations that might be expected to check the power of organized business have not kept up. ${ }^{121}$ Unions remain politically active and continue to provide substantial campaign donations, but because there are so few of them and their funding is increasingly under attack, they do not represent a significant share of organizational activity in politics and governance. ${ }^{122}$ Meanwhile, new organizations representing poor and middle-income

118 As political scientists Jacob Hacker and Paul Pierson write, " $[w]$ hile there are many 'liberal' groups in the universe of organized interests, labor has been the only organized interest focused on the broad economic concerns of those with modest incomes." Hacker \& Pierson, supra note 90, at 186.

119 See SCHLOZMAn ET AL., supra note 90, at 87-89. In the 1950s, roughly one in three workers in the United States belonged to a labor union. Id. Since then, union density has fallen precipitously. In 2010, around $11.9 \%$ of Americans were in unions; within the private sector, the rate in 2010 fell to about $6.9 \%$. Id. For a discussion of causes of the decline, see Richard B. FreEMAN, AMERICA WORKS: THE EXCEPTIONAL U.S. MARKET (2007).

120 See Katznelson, supra note 32, at 190-92, 204.

121 In recent years, business organizations have consistently comprised between ninety and ninety-five of the top 100 lobbying organizations, as measured by lobbying expenditures; in four of the last fifteen years not a single public interest group or union has appeared in the list of top 100 organizations. DRUTMAN, supra note 5, at 12-13. In 2012, business organizations spent $\$ 34$ for every $\$ 1$ spent by public interest groups and unions combined. $I d$. at 13. Political activities that are not disclosed in lobbying expenditures, such as talking to the press, coalition building, and grass-roots lobbying, however, are not included in these figures. Id. at 14. But there is no evidence that unions and public interest organizations even the spending disparity when such activity is considered. Id.

122 See SCHLOZMAn ET AL., supra note 90, at 368 (explaining that the decline in private-sector union membership and relative increase in "educational attainment of union members" may be related to "a weakened political voice on behalf of the economic interests of those lower down on the economic ladder"); Hacker \& Pierson, supra note 90, at 179-80 (discussing how the decline in organized labor has diminished the political voice of middle class Americans). In 2012, corporations spent $\$ 2.57$ billion on reportable lobbying expenditures, which amounted to fifty-six times the amount spent by unions. DRUTMAN, supra note 5, at 8-9, 14. Recent legislative and court decisions prohibiting unions from collecting fees from objecting workers, while maintaining the obligation that unions represent such workers, further weaken unions' economic and political position. See, e.g., Harris v. Quinn, 134 S. Ct. 2618 (2014) (holding that the agency-fee provision of Illinois's Public Labor Relations Act, which required non-union Medicaid-funded homecare personal assistants to pay fees to the union representing such assistants, violates the First Amendment). 
Americans have not filled the void. Such groups register barely a trace in studies of the organizational landscape of government. ${ }^{123}$

\section{B. Organized Wealth in the Branches}

The Framers of our Constitution, and Madison in particular, were concerned about the concentration of state power in few hands. ${ }^{124}$ As James Willard Hurst described the sentiment some years ago, "[w]e don't want to trust any group of power holders to be judges upon the ends for which they use the power or the ways in which they use it." ${ }^{125}$ "All forms of organized power over men's wills should in some way be accountable to serve ends of broader concern that the purpose of the power holders." 126

One mechanism to diffuse power was the separation of functions across three branches of government. ${ }^{127}$ The branches, at least according to the schematic version of American constitutionalism, would check one another in a way that respected the powers and prerogatives of each. Through the branches, "ambition [would] be made to counteract ambition." ${ }^{128}$ Consistent with this account of separation of powers, courts have frequently declined to decide separa-

123 See SCHLOZMAN ET AL., supra note 90, at 357 (noting that organizations that represent the interests of lower-income Americans only accounted for a small percentage of the organizations involved in Washington politics).

124 See, e.g., The Federalist No. 47, supra note 60 at 301 (James Madison) ("The accumulation of all powers, legislative, executive, and judiciary, in the same hands, whether of one, a few, or many, and whether hereditary, self-appointed, or elective, may justly be pronounced the very definition of tyranny."); THE FEDERALIST NO. 48, supra note 60, at 308 (James Madison) (stating that the central challenge faced in designing governance institutions is to assure "'practical security' ... against the excessive concentration of political power").

125 James Willard Hurst, Problems of Legitimacy in the Contemporary Legal Order, 24 OKLA. L. REV. 224, 225 (1971).

126 JAMES Willard Hurst, Justice Holmes on Legal History 29 (1964).

127 In referring to this conception of separation of powers as "Madison's conception," I adopt the dominant description in the literature but take no position on whether Federalist No. 51 accurately or fully reflected Madison's thoughts on the matter. Accord Bradley \& Morrison, supra note 54, at 438-39 n.112 (declining to take a position on whether Federalist No. 51 accurately portrays Madison's thoughts on the separation of powers) (citing Samuel Kernell, "The True Principles of Republican Government": Reassessing James Madison's Political Science, in JAMEs Madison: The Theory AND Practice of Republican Government 92, 93 (Samuel Kernell ed., 2003)) (arguing that the "Madison Model" of checks and balances in Federalist No. 51 is not a true reflection of Madison's views on the Constitution).

128 The Federalist No. 51, supra note 60. Such competition would police institutional boundaries and prevent tyrannical collusion. One of the virtues of this approach, Madison explained, is that it would not require that government officials act responsibly and police themselves. Rather, the model reflects a "policy of supplying, by opposite and rival interests, the defect of better motives." Id. 
tion of powers controversies. ${ }^{129}$ Instead, they have deferred to the branches themselves to reach political accommodations, except when one branch threatens to aggrandize itself at the expense of another. ${ }^{130}$ But, of course, as Madison himself recognized, the branches of government are not political actors with interests and wills of their own. Rather, the behavior of the branches is a product both of institutional structure and of the wills and interests that motivate the individual officials who populate them. ${ }^{131}$

There are many different constituencies, experiences, and interest groups that shape the wills and motivations of the leaders of government. But money is central to the story. Campaign spending is the most familiar mechanism by which wealth influences the political system. Wealthy individuals expend vast sums of money on campaigns through independent campaign spending and direct campaign contributions. ${ }^{132}$ Confirming long-held intuitions, recent empirical studies demonstrate that such spending results, at the very least, in greater access to members of Congress and their staffs. ${ }^{133}$ Other scholars conclude that money does much more, ultimately resulting in the corruption of Congress. ${ }^{134}$

129 Daryl J. Levinson, Empire-Building Government in Constitutional Law, 118 HARV. L. REV. 915, $950(2005)$.

130 See, e.g., Morrison v. Olson, 487 U.S. 654, 693 (1988); Bowsher v. Synar, 478 U.S. 714, 727 (1986).

131 See Kenneth A. Shepsle, Congress Is a "They," Not an "It": Legislative Intent as Oxymoron, 12 INT'L REV. L. \& ECON. 239, 249 (1992) (arguing against the use of legislative intent on the ground that individuals, not Congress as a collective, have intentions and purpose); Levinson \& Pildes, supra note 9, at 2317 (arguing that the government does not have interests of its own, but rather government behavior is driven by the wills and interests of individual government officials). As scholars have pointed out, the Madisonian model never made clear precisely how tension and competition between the branches were supposed to operate. The model assumes that differences in election and tenure among the branches would foster desired attachment, but it does not provide a mechanism by which the interests of actual public officials would be channeled into maintaining the role for their respective branches. Levinson \& Pildes, supra note 9, at 2317; see also M. Elizabeth Magill, The Real Separation in Separation of Powers Law, 86 VA. L. REV. 1127, 1158 (2000) (arguing that formal mechanisms such as the presidential veto and senate confirmation power do not guarantee a balance of power).

132 See, e.g., Confessore et al., supra note 5 (explaining that a small number of wealthy individuals are responsible for a siginificant percentage of campaign finance donations for the 2016 presidential election).

133 Joshua L. Kalla \& David E. Broockman, Campaign Contributions Facilitate Access to Congressional Individuals: A Randomized Field Experiment, AM. J. POL. SCI., Jan. 2015, at 11 (providing results from a study that demonstrate that contributions by organized interests can help increase access to policy makers).

134 See, e.g., LESSIG, supra note 6, at 89, 91 (arguing that congressional corruption is largely a result of the dramatic increase in campaign finance). 
But while campaign spending has occupied a great deal of attention from the public and legal scholars, it is only a small piece of the puzzle. $^{135}$ Indeed, businesses focus far more energy and resources on strategies other than campaign spending. One recent study reports that almost thirteen times more money is spent on lobbying and related forms of political persuasion than on campaigns. ${ }^{136}$

The business of persuading members of Congress to particular positions is multilayered and complex. Corporate and trade association lobbyists provide information in the legislative process by "call[ing] attention to issues, furnish [ing] evidence about how problems are being experienced on the ground, and provid[ing] expertise about the anticipated consequences-both substantive and political—of proposed solutions." ${ }^{137}$ In this way, business lobbyists make it easier for members of Congress to support certain policies; they "subsidize" the work involved. ${ }^{138}$ Indeed, the legislative system relies on the provision of expertise by industry lobbyists. Congressional staffers often lack the expertise and the time necessary to perform the detailed analysis lobbyists supply; staffers are often young, stretched thin over a number of issue portfolios, and less experienced than most lobbyists with whom they engage. ${ }^{139}$

Through sophisticated campaigns, organized business groups also supply pressure and mobilize congressional allies to take or block action on particular issues. ${ }^{140}$ And, increasingly, corporations are invest-

135 In the past couple of years, election law scholars have focused more attention on lobbying. See, e.g., Richard Briffault, The Anxiety of Influence: The Evolving Regulation of Lobbying, 13 ELEC. L. J. 160, 160 (2014) (discussing the four goals of lobbying regulation, which are "protecting the right to lobby; preventing improper influence; restricting some unfair opportunities for influence; and promoting transparency of lobbyists' activities"); see generally Richard L. Hasen, Lobbying, Rent Seeking, and the Constitution, 64 STAN. L. REv. 191 (2012) (arguing that lobbyists threaten economic welfare by facilitating rent-seeking activities and lobbying for legislation that is not an efficient use of resources); Zephyr Teachout, The Forgotten Law of Lobbying, 13 ELEC. L. J. 4 (2014) (analyzing the lobbying cases of the nineteenth and early twentieth century courts).

136 Lee Drutman, Despite Citizens United, Elections Aren't A Good Investment for Corporations, WASH. POST (Mar. 27, 2015), https://www.washingtonpost.com/opinions/despitecitizens-united-politics-isnt-a-good-investment-for-corporations/2015/03/27/f13e0d20d26c-11e4-ab77-9646eea6a4c7_story.html.

137 Schlozman ET AL., supra note 90, at 271. See also de Figueiredo \& Richter, supra note 107, at 5 (finding that "corporations and trade associations comprise the vast majority of the lobbying expenditures by interest groups").

138 See de Figueiredo \& Richter, supra note 107, at 5 (noting that lobbying expenditures by corporations and trade associations at the federal level accounts for "over $84 \%$ of interest group lobbying expenditures").

139 DRUTMAN, supra note 5, at 33-34.

140 Id. at 25-26; see also de Figueiredo \& Richter, supra note 107, at 164 ("If we assume, following most of political economy literature, that a politician's objective function is com- 
ing large sums in saturating the intellectual environment in order to influence policymakers and staffers. The goal, lobbyists report, is to legitimate certain arguments, ideas, and solutions. ${ }^{141}$ When countervailing organizations respond, they can be quite effective. But, as discussed above, they do so with a sliver of the resources and with declining numbers. On less salient and more complex issues, well-funded business groups are often the only real lobby. ${ }^{142}$

That elected officials are themselves affluent, frequently having served as leaders of or counselors to large business organizations, also works to shape the wills and interests of the branches. Officials bring their own beliefs and ideologies to bear on decisions they make. ${ }^{143}$ More often than not, these ideological positions are relatively stable. ${ }^{144}$ Perhaps not surprisingly, empirical work demonstrates that legislators from "profit-oriented jobs in the private sector ... tend to vote more conservatively on economic issues, especially compared to lawmakers who spent time in blue-collar jobs." ${ }^{145}$

While those who study campaign finance and lobbying have focused primarily on Congress, wealthy individuals and business organizations pervade the process of governing in the executive branch as well. ${ }^{146}$ Campaign spending obviously plays a role in presidential elections, ${ }^{147}$ and presidents, like members of Congress, have almost all been drawn from the elite. ${ }^{148}$ But wealth saturates the non-elected executive branch bureaucracy too, undermining many of the assump-

prised of re-election to the current office, promotion to higher office, and ideological pursuits, then the politician seeks information on how her position on a given issue or issue set will affect those outcome variables.").

141 DRUTMAN, supra note 5, at 36-37.

142 See SChlozman ET AL., supra note 90, at 285-87 (stating that many of the issues addressed by lobbyists for business interests were "relatively narrow and low-profile").

143 MCCARTY ET AL, supra note 93, at 21.

144 See $i d$. ("For the period covered by this book, there are only very small changes in legislator [ideological] positions.").

145 Carnes, supra note 98, at 11 . Wealthier legislators are also less likely to vote to repeal the estate tax, while legislators who are heavily invested in the stock market are more likely to vote to protect the market from regulation. Notably, states with more of these lawmakers have higher rates of economic inequality. Id. at 11-12.

146 Ken Godwin, et al., Lobbitng and Policymaking: The Public Pursuit of Private INTERESTS 207-08 (2013).

147 See, e.g., Blair Bowie \& AdAm Lioz, Billion-Dollar Democracy: THE UnPreCEDENTED Role of MONeY IN THE 2012 Elections, Demos 3 (2013), http://www.demos.org/ sites/default/files/publications/billion.pdf (revealing campaign spending in the 2012 presidential election cycle was over $\$ 2.6$ billion).

148 See, e.g., Douglas A. McIntyre, The Net Worth of The American Presidents: Washington To Obama, 24/7 WALL ST. (May 17, 2010), http://247wallst.com/banking-finance/ 2010/05/17/the-net-worth-of-the-american-presidents-washington-to-obama/. 
tions of scholars who celebrate internal or administrative separation of powers. ${ }^{149}$

Classic capture theory teaches that regulated industries enlist key members of Congress and the President to pressure agencies to promulgate favorable regulations or to shelve less favorable proposals; ${ }^{150}$ they do so by lobbying elected officials while promising financial or other support for reelection efforts. ${ }^{151}$ Because of their scant presence and their comparative resource weaknesses, public interest organizations are unable to curb the influence of organized business interests. ${ }^{152}$

Stated as such, capture theory is obviously flawed: Neither Congress nor the President is a puppet of a particular industry group, nor are the agencies mere pawns of their political overseers. Meanwhile, agencies differ from one another, making some more susceptible to capture than others: Some face a concentration of industry groups, the absence of countervailing organization, and a disputed mission,

See George J. Stigler, The Theory of Economic Regulation, 2 BELLJ. ECON. \& MGMT. SCI. 3, 12 (1971) (discussing "the costs" regulated industries must pay to obtain certain regulations); see generally Mancur Olson, JR., The Logic of Collective Action: Public GOODS AND THE THEORY OF GROUPS (1965) (discussing the concept of "pressure groups"). I use the term "classic" to refer to these works' position in the legal canon, for although the Chicago School and Stigler are often cited as the originators of capture theory, they were preceded by accounts of public corruption from the fields of political science and history, and before that by recognition of the problem of private interest in public governance that dates back to the founding. See William Novak, A Revisionist History of Regulatory Capture in Preventing Regulatory CaPture: Special INTEREST INFLUENCE AND How to Limit IT 25 (Daniel Carpenter \& David A. Moss eds., 2014).

151 On the way in which industry groups contribute to political campaigns and lobby in order to obtain influence with executive agencies' legislative overseers on the relevant oversight committees, see Einer R. Elhauge, Does Interest Group Theory Justify More Intrusive Judicial Review?, 101 Yale L.J. 31, 42 (1991). See also LawrenCe C. Dodd \& Richard L. SCHOtT, CONGRESS AND THE ADMINISTRATIVE STATE 103 (1979) (“[I]nterest groups [help] both the legislators and the bureaucrats by wining and dining them, lavishing benefits on them, giving them occasional insider information about investments, and, in the case of legislators, providing them with the financial support necessary to re-election."); J.R. DeShazo \& Jody Freeman, The Congressional Competition to Control Delegated Power, 81 TEX. L. REv. 1443, 1490 (2003) (explaining that an oversight committee's actions "can obstruct and delay the agency's agenda" and influence its decisions); Richard B. Stewart, The Reformation of American Administrative Law, 88 HARV. L. REV. 1667, 1685-86 (1975) (contrasting classic capture theory with "subtle" explanations of industry expectation or systematic bias); Barry R. Weingast \& Mark J. Moran, Bureaucratic Discretion or Congressional Control? Regulatory Policymaking by the Federal Trade Commission, 91 J. POL. ECON. 765, 779, 792 (1983) (asserting "that firms located in districts represented on FTC oversight committees are favored in the commission's antitrust decisions" and that " $t \mathrm{t}]$ he statistical evidence implies that the FTC is remarkably sensitive to changes in the composition of its oversight subcommittee").

152 See supra notes 114-23 and accompanying text. 
while others regulate diverse entities, enjoy (or endure) participation from organized countervailing groups, and have a clear statutory mission. ${ }^{153}$ The recent experience with net neutrality is but one example of how the wealthiest organized groups do not always win out. ${ }^{154}$

Nonetheless, the empirical and theoretical research overwhelmingly supports a theory of "soft" capture in the executive branch. Wealthy interests engage the administrative state at every level, and with significant effect. ${ }^{155}$ Industry groups participate actively in the regulatory process, meeting with high-level agency officials and lowerlevel staffers and participating in reviews of proposed rules and regulatory-analysis documents before the Office of Management and Budget's Office of Information and Regulatory Affairs ("OIRA") ${ }^{156}$ Throughout the process, industry officials provide not only opinions, but also information about how the regulated industry functions. ${ }^{157}$ Particularly where agency activity involves complex and non-salient issues, under-resourced public interest and worker groups are less likely to provide contrary information. ${ }^{158}$ Well-financed groups are

153 For a discussion of the relationship between capture and agency design, see Rachel E. Barkow, Insulating Agencies: Avoiding Capture Through Institutional Design, 89 TEX. L. REV. 15, 22-23 (2010).

154 See Rebecca R. Ruiz \& Steve Lohr, F.C.C. Votes to Regulate The Internet As a Utility, N.Y. Times, Feb. 27, 2015, at B1-B2 (discussing the F.C.C.'s decision "to regulate broadband Internet service as a public utility" to ensure that "the Internet is not divided into . . . fast lanes ... for [those] who can afford it and slow lanes for everyone else" but noting industry's presence on both sides of the issue).

155 Nicholas Bagley \& Richard L. Revesz, Centralized Oversight of the Regulatory State, 106 COLUM. L. REv. 1260, 1284-85 (2006) (discussing the process by which interest groups secure favorable regulations); see also Ian Ayres \& John Braithwaite, Tripartism: Regulatory Capture and Empowerment, 16 LAW \& SOC. INQUIRY 435, 437-39 (1991) (describing various ways in which regulated entities interact with regulators).

156 McGarity, supra note 40, at 1671 ("When the agency publishes a notice of proposed rulemaking, the regulated companies typically dominate the public-comment process. They submit reams of material and lengthy briefs explaining why disfavored regulatory alternatives are unlawful, unduly burdensome, unsupported by the available technical studies, or unlikely to achieve the agency's desired goal."); see also Robert L. Rabin, Federal Regulation in Historical Perspective, 38 STAN. L. Rev. 1189, 1295-1315 (1986) (describing how the evolution of judicial review of agency rulemaking opened the door to industry challenges); Paul R. Verkuil, Judicial Review of Informal Rulemaking, 60 VA. L. REV. 185, 206 (1974) ("It has been widely assumed that [the arbitrary-and-capricious standard of judicial review] is applicable to informal rulemaking.").

157 See Mark Seidenfeld, Bending the Rules: Flexible Regulation and Constraints on Agency Discretion, 51 AdMIN. L. REV. 429, 464 (1999); Stewart, supra note 151, at 1713-14 (explaining that industry officials often provide information because "agency staff resources are normally limited in comparison to industry resources").

158 See Willian T. Gormley, Jr., Regulatory Issue Networks in a Federal System, 18 POLITY 595, 60607 (1986) ("When issues are highly complex and not very salient, conditions are ripe for policymaking by a power elite. The public is virtually excluded from the policymaking process, because the issues are too obscure and too abstruse."); McGarity, supra note 40, 
also able to monitor agencies and challenge administrative decisions that will negatively affect them. ${ }^{159}$ All else being equal, agencies would prefer not to become mired in legal challenges. Thus they often seek to work with, rather than against, business groups, particularly when countervailing organizations are absent or weak and where the agency's actions are unlikely to capture sustained public attention. ${ }^{160}$

Agency officials also often anticipate entering or returning to employment with the regulated industry once their government service terminates. ${ }^{161}$ As a result, public choice theory posits that they either consciously or subconsciously avoid aggressively pressing an agenda in opposition to the interests of the regulated industry. Although this

at $1745-47$ (describing how asymmetries in influence and information favor industry over public interest groups and individuals).

159 See Barkow, supra note 153, at 22 ("[R] egulated industries are well-financed and wellorganized, especially when compared to the general public and public interest groups. Industry groups are thus better positioned to monitor agencies closely and to challenge any and all agency decisions that will negatively affect them."); McGarity, supra note 40, at 1675-76 ("The industry, meanwhile, carefully monitors and frequently interacts with the agency as the agency sets its regulatory agenda."); see also Bagley \& Revesz, supra note 155, at 1298 (" $[\mathrm{I}]$ ndustry will have an advantage in monitoring agencies and in setting off [fire] alarms when its interests are threatened."); Marissa Martino Golden, Interest Groups in the Rule-Making Process: Who Participates? Whose Voices Get Heard?, 8 J. PUB. AdmIn. Res. \& THEORY 245, 252-57 (1998) ("Between 66.7 percent and 100 percent of the comments received were submitted by corporations public utilities, or trade associations."); Seidenfeld, supra note 157, at 464 (discussing means by which "regulated industries and interest groups with strong central staffs still occupy a favored position in regulatory and political structures that allows them an advantage in influencing agency decisions"); Wendy E. Wagner et al., Air Toxics in the Board Room: An Empirical Study of EPA's Hazardous Air Pollutant Rules, 9-10 (Ariz. Legal Studies Discussion Paper No. 10-01, 2009), http://ssrn.com/abstract=1443531 (describing how regulated parties are "heavily engaged-and in a greater proportion than public intrest groups-in attempting to influence the substance" of the comment process). See generally Stephen Croley, Theories of Regulation: Incorporating the Administrative Process, 98 COLUM. L. REV. 1 (1998) (summarizing studies showing that regulated interests participate to a much greater extent than public interest groups).

160 Barkow, supra note 153, at 22-23. See also Scott R. Furlong \& Cornelius M. Kerwin, Interest Group Participation in Rule Making: A Decade of Change, 15 J. PUB. ADMIN. Res. \& THEORY 353, 361 (2005) (finding that businesses are participating twice as much as public interest groups); Seidenfeld, supra note 157, at 464 ("A regulated entity frequently is a large corporation with resources to appeal agency decisions at every level.").

161 See Kay Lehman Schlozman \& John T. Tierney, Organized Interests and AMERican DEMOCRACY 342 (1986) (discussing "the revolving door" and problems associated with it); Christopher N. Camponovo, Indecent Proposal: Abraham Sofaer, Libya, and the Appearance of Impropriety, $21 \mathrm{~J}$. LEGAL PROF. 23, 27-29 (1997) (discussing benefits and problems associated with "the revolving door"); Marc T. Law \& Cheryl X. Long, What Do Revolving-Door Laws Do?, 55 J.L. \& ECON. 421, 421 (2012) ("Plans to pursue a subsequent career in the private sector may induce current public employees (for instance, regulators) to treat potential private sector employers favorably."). 
"revolving door" theory does not hold up in all contexts-for example, an aggressive track record as an enforcer can actually be a useful selling point when looking for post-government employment-the close affinity between regulators and industry at the very least shapes perspectives among policymakers. ${ }^{162}$

Finally, wealthy individuals and business organizations wield influence over government not only through traditional mechanisms of "capture" but also through actual responsibility for privatized government functions. ${ }^{163}$ In countless privatized areas of administration, outside firms are hired to administer the laws and programs whose substance they have already shaped. ${ }^{164}$ In addition, in a wide range of areas, industry is actually responsible for writing the federal regulatory standards that govern. Known as "incorporated-by-reference" rules or standards, these industry standards are incorporated into law only by reference and available to the public only at a charge. ${ }^{165}$ Through both of these mechanisms-private administration of government functions and private writing of government regulations-economic elites and their organizations thus exercise a degree of direct control, as well as indirect influence, over government's operation.

In short, business groups and wealthy individuals provide donations, information, and expertise, populate the ranks of government, and work to shape the intellectual and policy debate. This does not mean they "capture" Congress, the President, or the agencies. Government and government officials still often serve, or try to serve, a public interest. ${ }^{166}$ Countervailing groups still mobilize or try to mobi-

162 Compare David Zaring, Against Being Against the Revolving Door, 2013 U. ILL. L. REv. 507, 530-39 (examining post-employment of prosecutors in the Southern District of New York and concluding that prosecutors who go on to private sector careers do not tend to do the bidding of those they regulate while in public service) with Law \& Long supra note 161 , at 435 (reasoning that future employment hopes may influence public officials to favor industry).

163 See Edward Rubin, The Possibilities and Limits of Privatization, 123 HARV. L. Rev. 890, 895-96 (2010) (reviewing GOVERnMENT By CONTRACT: OUtSOURCing AND AMERICAN Democracy (Jody Freeman \& Martha Minow eds., 2009)) ("There can be no doubt that the last few decades of our nation's history have seen the privatization of many activities that were previously regarded as the preserve of public authority.").

164 See Jon D. Michaels, Privatization's Pretensions, 77 U. CHI. L. REV. 717, 719, 727 (2010) (discussing the increasing use and effects of privatization and government "workarounds"); Martha Minow, Outsourcing Power, 46 B.C. L. Rev. 989, 989 (2005) (discussing the degree to which the U.S. military has increased the scope and scale of its reliance on private security companies in recent decades.).

165 Nina A. Mendelson, Private Control Over Access to the Law: The Perplexing Federal Regulatory Use of Private Standards, 112 MICH. L. ReV. 737, 739 (2013).

166 See Daniel Carpenter \& David Moss, Introduction to Preventing Regulatory Capture: Special Interest AND How to Limit It 1, 11-12 (Daniel Carpenter \& David Moss eds., 
lize. ${ }^{167}$ But business organizations and wealthy individuals are ubiquitous at every step of the process. They continually check and balance-or prod and plea with-governmental actors, working to define the scope of public debate and the shape of governmental policy.

\section{Organized Wealth in the Parties}

Still, if political parties have replaced the political branches as the primary mechanism for political competition, then perhaps none of the above matters for constitutional structure. On this view, the political parties provide a distinct mechanism for political competition, a mechanism uninfected by, or at least unrelated to, the problems discussed above. In reality, however, wealthy individuals and business organizations pervade not only the political branches, but also the political parties. Any account of how the parties function as mechanisms of political competition thus must consider the role of money.

The two major parties in America draw support from different segments of the population, often dividing on class lines as well as on the basis of geography, race, and age. ${ }^{168}$ Yet both parties obtain most of their donations from "the richest communities." 169 And the leaders, nominees, and appointees from both parties are themselves overwhelmingly wealthy, with deep connections to corporations and the financial sector. ${ }^{170}$

2014) (distinguishing between "strong capture," which is uncommon, and "weak capture," which is ubiquitous).

167 DRUTMAN, supra note 5, at 43-44.

168 See Delia Baldassarri \& Andrew Gelman, Partisans without Constraint: Political Polarization and Trends in American Public Opinion 114 AM. J. Soc. 408, 440 (2008) (noting "the persistent importance of traditional social cleavages of class, race, and religiosity in determining voting behavior"); Andrew Gelman et al., Income Inequality and Partisan Voting in the United States, 5 SOC. SCI. Q. 1203, 1204 (2010) (describing partisan differences in voting by income).

169 James G. Gimpel et al., The Political Geography of Campaign Contributions in American Politics, 68 J. POL. 626, 629-30 (2006) ("[B] oth parties turn to the richest communities in the country for the bulk of their itemized contributions, and the wealthiest citizens provide those funds far out of proportion to their share of the population.").

170 See, e.g., Matt O'Brien \& Darla Cameron, Elizabeth Warren Was Right: The Links Between Citigroup and Government Run Deep, The WASH. Post WonkBlog (Dec. 16, 2014), http://www.washingtonpost.com/blogs/wonkblog/wp/2014/12/16/elizabeth-warrenwas-right-the-links-between-citigroup-and-government-run-deep/ (noting that seven highlevel officials in Democratic administrations have worked at Citigroup before or after their government service). Even the recent Tea Party Movement, self-avowedly populist in nature, was funded in large part by billionaires. See Frank Rich, The Billionaires Bankrolling the Tea Party, N.Y. TIMES, Aug. 29, 2010, at WK8 (discussing the "sugar daddies who are bankrolling" the American Tea Party). 
Meanwhile, contemporary political parties lack a grass-roots structure that facilitates participation by ordinary Americans. Today's political parties are relatively skeletal organizations, particularly as compared to political parties in most other countries and to our own parties at other points in history. ${ }^{171}$ They do not, for example, require regular payment of party dues or other forms of participation. ${ }^{172}$ Instead, party membership usually means simply checking a box on a voter registration card. Progressive Era reforms, such as the stateimposed requirement that political parties select nominees through primary elections, along with (salutary) prohibitions against political patronage, have weakened mechanisms that parties previously used to encourage rank-and-file participation. ${ }^{173}$ Indeed, today, at the national level, the formal parties function primarily as campaign service vendors and fundraising entities. ${ }^{174}$ And as the influence of Super PACs and other large-donor entities has increased within the ecosystems of the parties writ-large, the role of party activists and formal party leadership structures has declined. ${ }^{17}$

Not only are the active participants and funders of the two political parties wealthy, but on economic redistribution issues, these voters tend to agree, at least more so than the standard narrative suggests. Recent empirical work demonstrates that elite Americans place a much lower value on equality than other Americans, even when they self-identify as progressive Democrats. ${ }^{176}$

Relatedly, there is less space between the parties-or key segments therein-than the standard account in the separation-of-powers liter-

171 See Leon D. Epstein, Political Parties in the American Mold 144-47 (1986) (comparing American party organizations with other countries and addressing evolution of American parties over time).

172 Id. at $144-46$.

173 See Pildes, supra note 39, at 813, n.21 (describing doctrinal changes that led to these reforms and arguing that the result was a rise in political fragmentation and a decline of control by party leaders).

174 Andrias, supra note 117, at 48-49 (citing Daniel J. Galvin, The Transformation of Political Institutions: Investments in Institutional Resources and Gradual Change in the National Party Committees, 26 Stud. AM. Pol. Dev. 50, 52, 57-59 (2012)).

175 See Joseph Fishkin \& Heather K. Gerken, The Party's Over: McCutcheon, Shadow Parties, and the Future of the Party System, 2014 SUP. CT. REv. 175, 176-77 (2015) (discussing the growing financial role of Super PACs and shadow party groups and how these "outside groups have taken over many of [the official parties'] functions"). On the parties as ecosystems, with different power centers, nodes of influence, and multiple points of entry, see generally Kathleen Bawn et al., A Theory of Political Parties: Groups, Policy Demands and Nominations in American Politics, 10 PERSP. ON POL. 571 (2012) and Michael S. Kang, The Hydraulics and Politics of Party Regulation, 91 IOWA L. REV. 131 (2005).

176 Raymond Fisman et al., The Distributional Preferences of an Elite, 349 SCIENCE 1300, 1300 (2015), http://www.sciencemag.org/content/349/6254/aab0096.full. 
ature would suggest. In the legal literature, the account is of two highly ideological and cohesive political parties, representing two ideological poles. One party is liberal, the other conservative, with great difference between them. ${ }^{177}$ Recent political science scholarship shows that, in fact, party polarization has been asymmetric and uneven, particularly on economic issues. Rising inequality is a major factor in this asymmetric polarization. ${ }^{178}$ Behavioral changes have largely been driven by the re-positioning of the Republican Party, with House Republicans in particular moving dramatically to the Right since the 1970s, a period during which economic inequality has increased. ${ }^{179}$ During this same period, congressional Democrats as a group have moved only slightly to the left, and the shift has occurred largely because of the disappearance of conservative Southern "Blue Dog” Democrats. Those Democrats remaining in office and their successors have not themselves shifted substantially left, particularly on economic issues. ${ }^{180}$ Meanwhile the Democratic platform has at least episodically moved away from "general welfare issues to issues based on ascriptive characteristics (race, gender, and sexual preference) of individuals." ${ }^{\prime 181}$

More importantly for this Article's focus, both parties have shifted toward more neoliberal economic policies or market conservatism. ${ }^{182}$

177 Legal scholars who focus on partisanship tend to describe the parties as fierce and equal contenders, representing two poles of public opinion. See, e.g., Levinson \& Pildes, supra note 9, at 2332-38 ("Partisan competition in government now means a Democratic Party dominated by liberals, with few moderates and no conservatives, pitted against a Republican Party dominated by conservatives, with few moderates and no liberals.").

178 See MCCARTY ET AL., supra note 93, at 71-109 (advancing income inequality as a major factor in polarization).

179 Michael Barber \& Nolan McCarty, Causes and Consequences of Polarization, in NEGOTIATING AgreEments in Politics 19, 21 (Jane Mansbridge \& Cathie Jo Martin eds., 2013); Nolan McCarty, et al., Polarization is Real (and Asymmetric), The Monkey CAGE (May 15, 2012), http://themonkeycage.org/2012/05/polarization-is-real-and-asymmetric/. On the move of the Republican Party to the right, see Jacob Hacker \& Paul Pierson, Winner-TakeAll Politics: How Washington MAde THE Rich Richer-AND TURNED ITS BACK ON THE MidDLE Class 171 (2010); MANN \& ORENSTEIN, supra note 1, at 51-56.

180 McCarty, et al., supra note 179.

181 MCCARTY ET AL., supra note 93, at 11. Among other explanations for the shifting focus of the Democratic Party is the transformation of the labor movement, beginning in the 1940 s, from a broad based social movement focused on the state to an interest group focused on private collective bargaining. See Nelson Lichtenstein, From Corporatism to Collective Bargaining: Organized Labor and the Eclipse of Social Democracy in the Postwar Era, in THE RISE AND FALl OF THE NEW DEAL ORDER, 1930-1980, at 122, 122-52 (Steve Fraser \& Gary Gerstle eds., 1989) (examining trade unions, labor, and the role of Progressives in generating reform for growing inequalities in power and income).

182 See, e.g., Bonica et al., supra note 97, at 104, 106-07. The "slight liberal drift" of the Democrats has been "compositional in nature," with moderate Democrats from the South being replaced by conservative Democrats. Id. at 106. Meanwhile, both parties have experi- 
As political scientists Nolan McCarty, Keith Poole and various coauthors have shown in a series of studies, while the Democrats are still more closely allied with labor and lower-income voters, both parties have experienced an ideological shift toward acceptance of a "form of free market capitalism" which offers "less support for government provision of transfers, lower marginal tax rates, and deregulation." 183 Though to different extents, for the last several decades, key segments of both parties have shared the view that the primary job of government is to protect financial markets and financial interests. ${ }^{184}$ To be sure, there are substantial differences between the positions of the Democratic and Republican Parties on economic and social welfare issues, and these positions continue to evolve, with Democratic leaders showing renewed interest in populist policies over the last couple of years. But the scope of that disagreement is different than the dominant story of hyper-polarization would suggest.

Moreover, because of our constitutional structure, wealthy interests need only exercise a degree of bipartisan influence to serve as an effective check on government: They need only exercise sufficient influence across the parties to be able to exploit critical veto points. ${ }^{185}$ Accordingly, business interests, in particular, tend to contribute strategically to members of both parties in order to obtain influence over key chokeholds. ${ }^{186}$ Studies on the campaign activity of the financial

enced an ideological shift toward acceptance of a "form of free market capitalism" which offers "less support for government provision of transfers, lower marginal tax rates, and deregulation." Id. at 104. For discussion of Democratic and Republican party shifts in recent years, see generally HACKER \& PIERSON, supra note 179; MCCARTY ET AL., supra note 93; Thomas Byrne Edsall, The Changing Shape of Power: A Realignment in Public Policy in THE Rise AND FALl OF THE NeW DEAL ORDER, 1930-1980, at 269-70 (Steve Fraser \& Gary Gerstle eds., 1989) ("The past twenty years, in effect, produced a policy realignment in the absence of a political realignment. The major beneficiaries of this policy realignment are the affluent, while those in the bottom half of the income distribution, particularly those whose lives are the most economically marginal, have reaped the fewest rewards."). See, e.g., Bonica et al., supra note 97, at 104, 106-07.

184 See Edsall, supra note 182, at 270-71; James K. Galbraith, The Surrender of Economic Policy, THE AMERICAN PROSPECT (Dec. 19, 2001), http://prospect.org/article/surrendereconomic-policy ("Across the spectrum, all declare the main job of government is to help markets work well.").

185 For an account of parties as ecosystems, with different power centers, nodes of influence, and multiple points of entry, see Joseph Fishkin \& Heather K. Gerken, The Two Trends That Matter for Party Politics 89 N.Y.U. L. Rev. OnLINE 32, 35 (2014) (citing Kang, supra note 175 and Kathleen Bawn et al., A Theory of Political Parties: Groups, Policy Demands and Nominations in American Politics, 10 PERSP. ON POL. 571 (2012)).

186 See Phillip Bump, Democrats Who Voted For the Cromnibus Have Received Twice as Much Money From the Finance Industry as the 'No' Voters, WASH. POST THE FIX (Dec. 12, 2014), http:/ /www.washingtonpost.com/blogs/the-fix/wp/2014/12/12/democrats-who-votedfor-the-spending-bill-have-received-twice-as-much-money-from-the-finance-industry-as-the- 
industry illustrate the dynamic: Financial industry members contribute in great numbers and great amounts to political campaigns of candidates from both parties. But they target money where it is likely to have the most influence. They give, in particular, to members on the Financial Services Committee of both parties, who are likely to set the legislative agenda, and they give to the more economically conservative wings of each party, who are most aligned with the policy positions of the industry. ${ }^{18}$

Historical and empirical work regarding the relative positions of Democrats and Republicans on measures designed to ameliorate inequality and regulate business confirms the success of the strategy: Through money and organization, wealth has been able to eliminate, from decisive sectors of both political parties, support for redistributive measures and greater regulation of the corporate sector. ${ }^{188}$ Though the Democratic Party and Republican Party advance opposing positions on many economic issues, key members do not, particularly with regard to low-salience issues of concern to organized business. The parties diverge substantially, but wealth influences enough members of both parties to narrow the effective gap in practice.

\section{A Coda: Outcomes for Governance}

While it is clear that economic elites and large business organizations pervade the political parties and the political branches, it is harder to measure how precisely their participation affects outputs. Political theorists have long worried that "those with greater property

no-voters (discussing strategic donations by the finance industry); AMERICANS FOR CAMPAign Reform, MONey IN POlitics: Who Gives (2010), http://www.acrreform.org/ wp-content/uploads/2010/12/Fact-Sheet-Who-Gives.pdf (finding that, in the 2010 election cycle, "[i]ndustry giving to the two major political parties was roughly even across sectors").

187 See Nolan McCarty et al., Political Bubbles: Financial Crises and the Failure of AMERICAN DEMOCRACY 83-85 (2013).

188 See, e.g., Carnes, supra note 98, at 19-21 (exploring data that show the relationship between socioeconomic status and legislation); Edsall, supra note 182, at 270 (discussing policy realignment and its affect on different socioeconomic classes). The recent vote on the Cromnibus bill provides a vivid example. See supra note 186 (describing greater total campaign contributions for Democrats who voted for a spending bill than Democrats who did not). For a discussion of the ways in which wealth influences the conservative legislative agenda, see Jane Mayer, Covert Operations: The Billion Brothers Who are Waging a War Against Obama, THE New Yorker, Aug. 30, 2010, at 45-46, 55 (discussing the growing political influence of the Koch brothers); Peter Hamby, Company Men: The U.S. Chamber Flexes Its New Political Muscle, CNN, http://www.cnn.com/interactive/2014/politics/ hamby-midterms-chamber-tea-party (last visited Feb. 10, 2015) (describing the increasing influence of the U.S. Chamber of Commerce). 
and wealth" would capture "the electoral process to their advantage." for this notion, with some prominent scholars concluding that government outcomes favoring the wealthy cannot be explained by a failure of democratic responsiveness. Rather, poor Americans, like their wealthy counterparts, simply did not favor downward redistribution or restrictions on corporate power. ${ }^{190}$

More recent empirical research, however, provides substantial support for theorists' concerns that government is ultimately more responsive to both wealthy individuals and organizations representing business interests. Most notably, in a recent study of two decades of congressional lawmaking, Martin Gilens found that "under most circumstances, the preferences of the vast majority of Americans appear to have essentially no impact on which policies the government does or doesn't adopt." 191 Other researchers' work in the last few years confirms these conclusions. ${ }^{192}$

The extent to which the views of wealthy Americans diverge from those of lower-income Americans is disputed. On many issues there appears to be little divergence. But recent studies suggest that the general public is more amenable than the wealthy to a variety of policies designed to reduce inequality and strengthen economic opportunity, including raising the minimum wage, increasing the Earned Income Tax Credit, providing greater unemployment benefits, and directly creating jobs. ${ }^{193}$ For example, only $40 \%$ of the wealthy think

189 John RaWls, Political Liberalism 360 (1993); see also Michael WALzer, SpHERes of JUSTICE: A DEFEnSE OF PluRALism AND EQuality 310 (1983) ("The most common form of powerlessness in the United States today derives from the dominance of money in the spehere of politics."). For a discussion of this strand of political theory, see Sachs, supra note 26 , at $159-60$ (2013).

190 See generally JENNIFER HOChSChILD, What's FAIR?: AMERICAN Beliefs About DistRIBUtIVE JUSTICE (1981) (finding, through qualitative interviews, significant ambivalence among working-class Americans about downward redistribution). For an overview of these debates, see Who GETS REPRESENTED? (Peter K. Enns \& Christopher Wlezien, eds., 2011); Jennifer Hochschild, Winner-Take-All Politics: A Review Essay, 126 POL. SCI. Q. 315, 318 (2011) (reviewing Jacob S. Hacker \& Paul Pierson, Winner-Take-All Politics: How Washington MAde THE Rich Richer-AND TURNEd ITS BaCK ON THE MidDLE Class (2010)).

191 Martin Gilens, AfFluence And Influence: Economic Inequality and Political POWER IN AMERICA 1 (2012).

192 See generally Larry M. Bartels, Unequal Democracy: The Political Economy of the New Gilded Age (2008); Callahan \& Mijin Cha supra, note 98; Gilens, supra note 191; HACKer \& PIERSON, supra note 179; SCHLOZMAn ET AL., supra note 90.

193 See generally Benjamin I. Page, et al., Democracy and the Policy Preferences of Wealthy Americans, 11 Perspectives on POL. 51-73 (2013) (comparing preferences of wealthy Americans with lower-income Americans). Affluent voters are also less supportive of labor unions and less likely to support laws that make it easier for workers to join unions. See JOHN 
the minimum wage should be high enough to prevent full-time workers from living in poverty, while $78 \%$ of the general public holds this view. ${ }^{194}$ A similar gap exists with regard to tax policy: A recent study found that $73 \%$ of Americans making under $\$ 20,000$ believed that the gap between rich and poor should be reduced, even if achieving that goal requires higher taxes, compared to $54 \%$ of Americans making over $\$ 100,000 .{ }^{195}$ Even where the wealthy, middle class, and poor agree on policy, they prioritize differently. Polls over the past several years have repeatedly found that addressing unemployment, creating jobs, and improving the economy are priorities for lower-income Americans, while higher-income Americans rank reducing the deficit as their top priority. ${ }^{196}$

Irrespective of the degree of divergence in views, when divergence occurs, members of Congress tend to respond to the views of wealthy individuals, from whom they regularly hear, as opposed to those of lower- and middle-income Americans, who participate much less and do so with less money and organization. ${ }^{197}$ For example, Gilens's study found that federal legislators "consistently appear to pay no attention to the views of millions of constituents in the bottom third of the income distribution." ${ }^{198}$ When preferences between the rich and the poor diverge, "government policy bears absolutely no relationship to the degree of support or opposition among the poor." 199 Even when middle-class preferences align with those of the poor, Congress is responsive to the affluent and not to the poor and middle classes. ${ }^{200}$

Halpin \& Karl Agne, Center for American Progress, State of American Political Ideology, 2009: A National Study of Political Values and Beliefs 30 (2009), http://www.americanprogress.org/wp-content/uploads/issues/2009/03/pdf/ political_ideology.pdf (finding "attitudes toward unions are closely tied to education, with college-educated Americans of every ideology being 6-to-12 points less likely to agree" that unions are important). The affluent are also significantly less inclined than other groups of Americans to support an active role for government in addressing mass unemployment. Enns \& Wlezien, supra note 190.

196 Id. at 5-6, nn.6-8 (collecting polls). Results of a pilot study of the Survey of Economically Successful Americans ("SESA") showed that $87 \%$ of affluent households believed budget deficits were a "very important" problem, the highest percentage of all listed problems. Page et al., supra note 193, at 54.

197 SChlozMAn ET AL., supra note 90, at 6.

198 BARTELS, supra note 192, at 282.

199 GILENS, supra note 191, at 81.

$200 I d$. at 84 . Gilens concluded that representational inequality is genuinely rooted in economic inequality and cannot be reduced to partisan bias, and he noted the dwarfing of small donations by affluent donors to political campaigns. Id. at 247-48. 
Business organizations similarly affect legislative outcomes. Gilens and Page found that organizations representing business in governance are relatively cohesive in their positions on economic policy questions in ways that correlate negatively with the preferences of average citizens. ${ }^{201}$ And, along with their wealthy owners and leaders, business groups substantially affect legislative outcomes, whereas the scant groups representing ordinary citizens have little aggregate effect. ${ }^{202}$ This should not be surprising given that, as previously discussed, the composition of the U.S. interest groups is heavily tilted toward corporations and business associations and business groups are by far more active and better funded. ${ }^{203}$ And the trends hold no matter which party is in power. ${ }^{204}$ The related data on economic distribution is consistent: Inequality has increased more quickly during Republican administrations, ${ }^{205}$ but it has also increased during periods of Democratic control. ${ }^{206}$ And the gap has widened during both divided and unified government. ${ }^{207}$

Wealthy interests also shape regulatory outcomes, though here the role of business is far greater than that of wealthy individuals. Agency responsiveness to the desires of the industry or groups being regulated is well modeled as a theoretical matter and well documented as an empirical matter. ${ }^{208}$ As Richard Stewart has observed, "[i]t

201 Gilens \& Page, supra note 5, at 574.

202 Id. at 572

203 Id. at 574-75; see also supra notes 113-23 and accompanying text. Gilens and Page's research is consistent with prior studies showing a clear bias in legislative outcomes to the wealthy. E.g., BARTELs, supra note 192; FRANK BAUMGARTNER ET AL., LOBBYING AND Policy Change: Who Wins, Who Loses, AND Why (2009).

204 GILENS, supra note 191, at 178; Gilens \& Page, supra note 5, at 573-74.

205 Scholars attribute this to differences in macroeconomic and tax-and-transfer policies. See BARTELS, supra note 192, at 31-34, 104-05 (citing and extending the research in Douglas A. Hibbs, Jr., The American Political Economy: Macroeconomics and Electoral Politics (1987) and Douglas A. Hibbs, Jr. \& Christopher Dennis, Income Distribution in the United States, 82 AM. POL. SCI. REV. 467-90 (1988), which indicates Republican macroeconomic policies are the culprit, and citing EDWARD R. TUFTE, POLITICAL CONTROL OF THE ECONOMY (1978) as confirmation of the effects of Republican transfer policies).

206 See Lane Kenworthy, How Much Do Presidents Influence Income Inequality? 53 CHALLENGE 90, 92-96, 103-08 (2010) (reviewing Bartels's research but finding that inequality has also increased under Democratic administrations since the 1970s). Notably, the relationship between the President's party and patterns of income growth weakened considerably after the 1970s when the organizational landscape of American politics shifted. Since the 1970s, income inequality has risen sharply and the correlation between the President's party and movement in inequality has been much weaker than in earlier years. Id. at 107 .

207 Id. at 92.

208 See Roger G. Noll, Reforming Regulation: an Evaluation of the Ash Council PROPOSALS: A STAFF PAPER 99-100 (1971) (explaining that capture happens most often when an agency assigns undue weight to the interests of the regulated industries as 
has become widely accepted, not only by public interest lawyers, but by academic critics, legislators, judges, and even by some agency members, that the comparative overrepresentation of regulated or client interests in the process of agency decisionmaking results in a persistent policy bias in favor of these interests." 209 That is not to say agencies fail to regulate in the public interest at all, but they often become closely identified with and dependent on the industries they are charged with regulating. ${ }^{210}$ Several different researchers find systematic biases that favor regulated parties in rules promulgated by several different agencies. The bias exists even in agencies like the Environmental Protection Agency ("EPA") that are generally viewed as resistant to traditional forms of agency capture. ${ }^{211}$ Of course, it is sometimes hard to identify when an agency decision is the product of undue interest group pressure as opposed to an exercise of the agen-

against those of the public); Croley, supra note 126, at 5 (describing the concept of agency capture as an essential component of the public-choice theory of regulatory process, which maintains that agencies cater to the regulatory needs of well-organized interest groups). For helpful overviews of capture, see PAUL J. QUIRK, INDUSTRY INFLUENCE IN Federal Regulatory AgENCiEs (1981); Bagley \& Revesz, supra note 155, at 1260; Stewart, supra note 151; George J. Stigler, The Theory of Economic Regulation, 2 BELL. J. ECON. \& MGMT. SCI. 3 (1971).

209 Stewart, supra note 151, at 1713 quoted in Barkow, supra note 153, at 21-22; see also Stewart, supra note 151, at 1685 ("At its crudest, this thesis is based on the 'capture' scenario, in which administrations are systematically controlled, sometimes corruptly, by the business firms within their orbit of responsibility, whether regulatory or promotional."). For cases discussing regulatory capture, see, for example, Adkins v. VIM Recycling, Inc., 644 F.3d 483, 499 (7th Cir. 2011) (noting that "regulatory agencies are subject to the phenomenon known as 'agency capture'”); Wood v. General Motors Corp., 865 F.2d 395, 418 (1st Cir. 1988) (describing agency capture as the "undesirable scenario where the regulated industry gains influence over the regulators, and the regulators end up serving the interests of the industry, rather than the general public").

210 Merrill, supra note 33, at 1060 (citing MARVER H. BERnSTEIn, REgUlating Business BY INDEPENDENT COMMISSION 79-94 (1955)).

211 Martino Golden, supra note 126 (studying rules promulgated by federal agencies using content analysis to determine private citizen comment participation and organized influences on federal regulations and finding no citizen group engagement in five of eight rules promulgated by EPA); Wendy Wagner et al., Rulemaking in the Shade: An Empirical Study of EPA's Air Toxic Emission Standards, 63 ADMIN. L. REV. 99, 108-09 (2011) (citing Maureen L. Cropper et al., The Determinants of Pesticide Regulation: A Statistical Analysis of EPA Decision Making, 100 J. POL. ECON. 175, 178, 187 (1992)) (examining interest group engagement in pesticide registrations between 1975 and 1989 and finding environmentalists participated in forty-nine percent of the cancellations); Jason Webb Yackee \& Susan Webb Yackee, A Bias Towards Business? Assessing Interest Group Influence on the U.S. Bureaucracy, 68 J. POL. 128, 131, 133 (2006) (studying forty lower-salience rulemakings promulgated by four different federal agencies and finding that business interests submitted $57 \%$ of the comments, whereas nongovernmental organizations submitted $22 \%$ of comments, only $6 \%$ of which were submitted by public interest groups). 
cy's independent judgment. ${ }^{212}$ But notwithstanding limitations of public choice theory, there is little dispute that, overall, organized business and wealthy interests participate at far greater rates than others, and with significant effect.

\section{ASSESSING THE "FIFTH BRANCH": THE EFFECTS OF ORGANIZED WEALTH ON EXECUTIVE POWER AND LEGISLATIVE CAPACITY}

The focus thus far has been on the extent to which wealth influences the political branches, the political parties, and the executive branch bureaucracy. This Part builds on that analysis, demonstrating that existing descriptive accounts of executive and legislative power need revision. It shows that because of the influence of wealth on a host of important issues, unified government is more constrained in its output than dominant constitutional theories suggest; gridlock is more biased in its operation and results; and internal checks are less effective at diffusing concentrated power and enabling innovation than proponents assert.

To be clear, the partisanship story dominant in the law review errs not because it expressly asserts hyper-polarization on economic matters. Rather, the literature typically speaks in generic terms about intense polarization, without considering the role of wealth. That is, those who write about government dysfunction frequently evoke partisanship in expansive terms without drilling down into where and when issues are polarized-and where and when they are not. In the words of one recent piece, "In our highly polarized system, it sometimes seems like we disagree on everything."

The number of recent articles invoking hyper-polarization or intense partisanship as the cause of government dysfunction, without

212 See, e.g., Protecting the Public Interest: Understanding the Threat of Agency Capture: Hearing Before the S. Subcomm. on Admin. Oversight and the Courts, 111th Cong. 6-7 (2010) (statement of Nicholas Bagley, Assistant Professor of Law, Univ. of Michigan Law Sch.) ("Capture is ... often very hard, if not impossible, to reliably identify."). Public choice theory can be taken too far. Theorists err to the extent they define the legislative process as merely an arena for fundamentally self-serving behavior or to the extent they fail to recognize the plurality of interests and motivations at play. For critiques of public choice theory of regulation, see generally DONALD P. GREEN \& IAN SHAPIRO, PATHOLOGIES OF RATIONAL Choice Theory: A Critique of Applications in Political Science (1994); Mark Kelman, On Democracy Bashing: A Skeptical Look at the Theoretical and "Empirical" Practice of the Public Choice Movement, 74 VA. L. ReV. 199 (1988); Richard H. Pildes \& Elizabeth Anderson, Slinging Arrows at Democracy: Social Choice Theory, Value Pluralism, and Democratic Politics, 90 COLUM. L. ReV. 2121 (1990).

213 Heather K. Gerken \& Ari Holtzblatt, The Political Safeguards of Horizontal Federalism, 113 MiCH. L. REV. 57, 96 (2014). 
qualification, is significant. ${ }^{214}$ And where the constitutional governance literature does recognize that wealthy interest groups and campaign money play a role in shaping partisanship, and in shaping governance, it tends to treat the dynamic as an exception to the basic rule, rather than as a systemic feature. ${ }^{215}$ Meanwhile, although some theorists have recognized that actors both internal and external to the government check partisan government-actors such as the media, watchdog groups, and foreign governments ${ }^{216}$ - even these accounts tend not to consider the systematic role played by wealthy interests. $^{217}$ As shown below, the picture drawn is incomplete. ${ }^{218}$

\section{A. Unified Government}

A central preoccupation of separation of powers and administrative law scholars is the growth of executive power over the last centu-

214 For just a few recent examples, see Zachary S. Price, Politics of Nonenforcement, 65 CASE W. RES. L. REV. 1119, 1121 (2015) (describing "intense political polarization and partisan disagreement over policy" as leading to nonenforcement); Daphna Renan, Pooling Powers, 115 COLUM. L. REv. 211, 235 (2015) (claiming our "age of divided and polarized government" has made it more difficult for the executive branch to respond to challenges with new legislation and identifying "pooling" of administrative resources as a tool to address those challenges).

215 Levinson and Pildes, for example, contend that association with a "party is likely to be the single best predictor of political agreement and disagreement." Levinson \& Pildes, supra note 9, at 2324-25. And although they concede that "[o]n certain aspects of trade and environmental policy, for example, the relevant cleavages may correspond more closely to geography and interest-group support than to party," id. at 2324, they treat the role of organized business interests on those issues as an unusual exception from the rule. Gillian Metzger acknowledges that economic inequality has helped contribute to polarization, but she too emphasizes that "[t]he signal characteristic of national politics today is increasing political polarization." Gillian E. Metzger, Appointments, Innovation, and the Judicial-Political Divide, 64 DUKE L.J. 1607, 1610, 1630-31 (2015).

216 See Jack Goldsmith, Power and Constraint: The Accountable Presidency After 9/11 (2012); ERIC A POSNER \& Adrian Vermeule, The EXeCUtive Unbound: AFter THE Madisonian RePUblic (2011); Ashley Deeks, Checks and Balances from Abroad, U. CHI. L. REv. (forthcoming 2016); Jody Freeman, The Private Role in Public Governance, 75 N.Y.U. L. REV. 543, 549 (2000).

217 But see Michaels, supra note 164, at 719 (describing various privatization practices as "executive aggrandizing").

218 Eric Posner and Adrian Vermeule, for example, use financial reform as a key example of how the executive is unconstrained by inter- and intra-branch checks, but checked by political forces. But they fail to consider the distribution of political power with respect to financial regulation. They point to the importance of whistleblowers, and general political backlash, barely mentioning the outsized role money plays in government. Perhaps for this reason, they are much more sanguine about the effectiveness of existing checks. See POSNER \& Vermeule, supra note 216; cf. GOLDSMITH, supra note 216 (describing various forms of watching and checking the presidency in the form of courts, members of Congress, human rights activists, journalists, lawyers, watchdog groups, whistleblowers, and others in the context of the war on terror). 
ry. Supporters of a strong, unitary executive celebrate the trend. They contend that the Constitution creates a hierarchical executive branch, with the President empowered to direct administration of all federal laws. ${ }^{219}$ Others are less convinced that the Constitution's text compels a strongly unitary executive, but assert that a powerful Executive is permissible, when authorized by Congress, and necessary to respond to exigencies of modern life. These theorists celebrate the distinct capacities of the executive: the ability to access vast amounts of information, act quickly and decisively, and adapt to changing circumstances. Numerous scholars, along with many Presidents and executive branch lawyers, advance this view. ${ }^{220} \mathrm{~A}$ third group worries intensely about the rise of executive power, arguing that expanded presidential authority poses a grave threat to the future of the United States' government. ${ }^{221}$

As a positive matter, however, there is little dispute: Our executive has expanded greatly since the Founding, and particularly so in recent years. ${ }^{222}$ Scholars point to partisanship as one explanation for why executive power has so expanded: During times of unified party government, the executive, beholden to a highly polarized and ideologically coherent party, pushes an aggressive, politically extreme legislative agenda. Congress is not only willing to enact partisan policy,

219 See, e.g., Steven G. Calabresi \& Saikrishna B. Prakash, The President's Power to Execute the Laws, 104 YALE L.J. 541, 550 (1994) (rejecting the theory that the concept of a unitary executive stemming from the Framers is a myth). For a history of the unitary executive theory, see generally Stephen Skowronek, The Conservative Insurgency and Presidential Power: A Developmental Perspective of the Unitary Executive, 122 HARV. L. REV. 2070 (2009).

220 For a recent and particularly robust expression of this view, see generally POSNER \& Vermeule, supra note 216. Others who emphasize the capacity of the Executive to respond to modern exigencies include Kagan, supra note 53, at 2255-56; Lawrence Lessig \& Cass R. Sunstein, The President and the Administration, 94 CoLuM. L. REV. 1, $85-86$ (1994).

221 See, e.g., ACkerman, supra note 3. See also Peter M. Shane, Madison's Nightmare: How Executive Power Threatens AmERICAN DEMOCRACY (2009) (arguing that presidents' increasingly assertive claims to unilateral authority have subverted constitutional checks and balances).

222 See, e.g., ACKERMAN, supra note 3, at 120 (" $[\mathrm{T}]$ oday, both major parties are in love with the presidency.”); Richard H. Pildes, Law and the President, 125 HARv. L. ReV. 1381, 1384 (2012) (reviewing Eric A. Posner \& Adrian Vermeule, The Executive Unbound: AFTER THE MADISONIAN REPUBLIC (2010)) ("Thus, presidential power expanded through liberal hands for most of the century, and just as liberals began to have second thoughts, conservatives propelled the expanding presidency further."). At the same time, Jerry Mashaw has demonstrated the degree to which the administrative state preceded the New Deal. Jerry mashaw, Creating the Administrative Constitution: The lost One HUNDRED YEARS OF AMERICAN ADMINISTRATIVE LAW 6 (2012) (“[T] here has been no precipitous fall from a historical position of separation-of-powers grace to a position of compromise; there is not a new administrative constitution whose legitimacy should be understood as not only contestable but deeply problematic."). 
but is more likely to delegate power to a fellow partisan and is unlikely to check abuses of that power. As a result, across administrations, during periods of unified government, the administrative state expands and the executive operates with few checks. ${ }^{223}$

The problem is that this account is essentially undifferentiated. It speaks about presidential power and hyper-polarization in general terms. As a result, it implies that partisanship explains government action across issue domains, and that executive power's expansion is trans-substantive. As discussed in Part II, however, polarization has been asymmetrical between the parties and uneven across issues. ${ }^{224}$ Because of organized wealth's systematic influence, executive power on a host of issues is more constrained, or differently constrained, than partisanship-focused law review literature on executive power would suggest.

The constraints imposed on unified government by wealth should be evident from Part II. Through campaign donations, lobbying, and participation throughout the bureaucracy and administrative process, wealthy individuals, businesses, and their organizations effectively check governmental efforts that oppose their interests, even during periods of unified government. And, indeed, empirical research suggests that proposals contrary to business interests, advanced during periods of unified government, have fared particularly poorly. Democratic administrations, which have pushed such proposals more frequently, thus appear to fare worse in terms of legislative output during periods of unified government. ${ }^{225}$

Recent experience illustrates the point: When, during the first years of the Obama Administration, both the executive and legislative branches were controlled by Democrats—with a filibuster-proof majority in the Senate-the parties-not-powers theory would suggest that we should have seen a great deal of legislation, easily passed. According to the theory, such legislation should have expanded the power of the executive immensely and should have advanced a hyper-partisan

223 William Howell, Power without Persuasion: The Politics of Direct Presidential ACTION 179-80 (2003). For legal scholarship discussing this trend, see Bradley \& Morrison, supra note 54, at 443; Levinson \& Pildes, supra note 9, at 2348-49; Marshall, supra note 49, at 519; Pildes, supra note 2, at 326, 333.

224 See supra Part II.C.

225 See David R. MaYhew, Partisan Balance: Why Political Parties Don't Kill the U.S. Constitutional System 66, 78-79 (2011). David Mayhew has found that during unified government Republican presidents have a $71.4 \%$ probability of success with high-priority proposals, compared with Democrats' $42.1 \%$, though he has advised against overinterpreting the data. $I d$. at 79 . 
liberal agenda. ${ }^{226}$ To some extent, that account holds up: The legislative achievements that preceded the Democrats' loss of Congress in 2010, primarily healthcare reform and financial regulatory reform, were significant progressive reforms. They also were politically polarizing and involved substantial new delegations to the executive branch.

But when one considers the entire process of enactment, as well as the legislation championed but not passed during the preceding political campaign, the picture is more complicated. Both the healthcare and financial reform laws were far harder to enact than the model offered by separation-of-parties scholars would have suggested. And the multiple veto gates that made enactment difficult systematically favored organized wealth, particularly regulated industry. Of course, wealthy interests were not the only groups involved in the governance process and wealthy individuals and groups were not monolithic in their views. But money served to constrain in ways that undermine, or at least amend, the narrative of an unchecked and hyper-partisan executive during times of unified government.

Consider the Dodd-Frank Wall Street Reform and Consumer Protection Act. Signed into law in July of 2010, Dodd-Frank included "a package of financial regulatory reforms unparalleled in scope and depth since the New Deal."227 A reaction to regulatory failings brought to light by the most severe financial crisis since the Great Depression, ${ }^{228}$ the Act was politically possible not only because of popular anger at the banks, but also because of unified government. But this is only part of the story. Despite both unified Democratic government and strong popular support, passing the legislation was immensely challenging. Moreover, the content of the legislation was systematically influenced by economic elites and business interests and, particularly in areas of low-light, this influence was largely unchecked by countervailing forces.

Financiers exercised their influence through multiple channels, consistent with the mechanisms described in Part II. For example, leading up to the writing of the legislation, they were more active in

\footnotetext{
226 To be clear, my argument does not rest on the notion that the Democratic Party is inherently liberal and that it somehow abandoned its true mission. Rather, my claim is simply that the narrative of hyper-polarization erroneously implies an ideological divide that in practice either does not always exist or does not always produce the division of powers asserted.

227 Heath P. Tarbert, The Dodd-Frank Act-Two Years Later, 66 CONSUMER FIN. L.Q. REP. 373, 373 (2012). 
politics than the average American. ${ }^{229}$ In particular, they were substantially more likely to contribute to ongoing campaigns, including, on occasion, through coordinated campaigns. ${ }^{230}$ Their contributions flowed to members of both political parties, as they targeted key Democrats while rewarding staunch Republican supporters. ${ }^{231}$ Following up on their campaign contributions, the industry spent a great amount of time and money lobbying. Meanwhile, Congress heard much less from consumers and their representatives-not surprisingly, for the issues were technically complex and consumer groups were comparatively smaller and less resourced. ${ }^{232}$ Meanwhile, past leaders of finance filled many of the relevant leadership positions of both the outgoing Bush Administration and the new Obama Administration.

Ultimately, although the banks were not able to stop DoddFrank's enactment, they were successful at limiting its reforms. This occurred despite an executive governing with a strong majority in Congress. ${ }^{233}$ In areas of low-light, the banks' checks and prods were particularly strong. For example, following the enactment of DoddFrank, Citigroup played a significant role in drafting a bill to exempt broad swathes of trades from new regulation. The bank's recommendations were reflected in more than seventy lines of the House committee's eighty-five-line bill. As The New York Times reported, "[t]wo crucial paragraphs, prepared by Citigroup in conjunction with other Wall Street banks, were copied nearly word for word." ${ }^{234}$

229 Eighty-eight percent of those employed in finance and insurance reported voting in the presidential election compared to $76 \%$ of other respondents. They were also more likely to try to influence the votes of others, attend a campaign meeting, rally or speech, and work on a campaign. MCCARTY ET AL., supra note 187, at 78-83 (2013).

$231 \quad I d$. at $83-85$.

232 Id. at $78-80$.

233 See Daniel Indiviglio, 5 Ways Lobbyists Influenced the Dodd-Frank Bill, THE ATLANTiC (July 5 , 2010), http://www.theatlantic.com/business/archive/2010/07/5-ways-lobbyistsinfluenced-the-dodd-frank-bill/59137/ (confirming the "watered-down" nature of the final Volcker Rule). Whether or not the original Volcker Rule would have been better policy, the bill simply does not reflect unchecked power of unified government. Rather, bank lobbyists played a major role in the shaping of the legislation, with little counterbalance from consumers. MCCARTY ET AL., supra note 187, at 186-87, 253; see also Kimberly D. Krawiec \& Guangya Liu, Pointless Pluralism? An Empirical Study of Volcker Rulemaking (unpublished manuscript) (on file with author) (undertaking a case study of the Volcker Rule and concluding that industry representation in formulation of rule dominated).

234 Eric Lipton \& Ben Protess, Banks' Lobbyists Help in Drafting Financial Bills, N.Y. Times DEALBOOK (May 23, 2013 9:44 PM), http://dealbook.nytimes.com/2013/05/23/bankslobbyists-help-in-drafting-financial-bills (adding that "[1]awmakers changed two words to make them plural"). 
Again, the point is not that the Dodd-Frank Act falls short of achieving its stated ambitions or that it fails to reform the industry in a way that will prevent future crises-many experts take that position, while others emphasize the important achievements of the Act. ${ }^{235}$ Rather, whatever the final Act's strengths or failings, what is important from a separation-of-powers perspective is that, throughout the lawmaking process, the financial industry provided substantial and systematic constraint on unified government, particularly on more technical issues of low-light, checking and prodding its actions. Meanwhile, countervailing voices of consumers were much fainter and more diffuse.

The story of healthcare reform similarly reflects the imposition of checks by regulated industry on the actions of unified government. According to nearly all observers, industry priorities fundamentally structured the healthcare reform bill. At every step in the legislative process, participation by business interests outweighed that of consumers. $^{236}$ And administration officials were frank that, in their view, the bill's ultimate success would depend largely on support from the relevant business interests, including the insurance and pharmaceutical industries. ${ }^{237}$ To be clear, the healthcare bill was a significant, even historic, progressive achievement. But the persistent influence of wealth, particularly business groups, demonstrates the degree to which unified government is checked-from a particular direction.

235 See, e.g., MCCARTY ET AL., supra note 187, at 253-54 (explaining that holes and uncertainties remain, despite the Dodd-Frank Act's new provisions); Ryan Bubb \& Prasad Krishnamurthy, Regulating Against Bubbles: How Mortgage Regulation Can Keep Main Street and Wall Street Safe-From Themselves, 163 U. PA. L. REV. 1539, 1542, 1544, 1629-30 (2015) (asserting that the Dodd-Frank Act is ineffective in achieving its goals); Saule T. Omarova, The Dodd-Frank Act: A New Deal for A New Age?, 15 N.C. BANKING INST. 83, 84-85 (2011) (claiming that the Dodd-Frank Act falls short of its "stated ambitions"); Arthur E. Wilmarth, Jr., The Dodd-Frank Act: A Flawed and Inadequate Response to the Too-Big-to-Fail Problem, 89 OR. L. REV. 951, 954 (2011) (asserting that the Dodd-Frank Act fails in its promise to prevent future taxpayer-funded bailouts).

236 For discussion of the politics of the bill's passage see, for example, LAWRENCE R. JACOBS \& Theda SKocPol, Health Care Reform and AMERICAN Politics: What EVERYONE NEEdS TO KNOW 7 (2010); JiLl QUAdagno, ONE Nation, Uninsured: Why the US Has No National Health Insurance 6 (2005); Elenora E. Connors \& Lawrence O. Gostin, Health Care Reform-A Historic Moment in U.S. Social Policy 303 J. AM. MED. Ass'N 2521-22 (2010); Arthur Daemmrich, U.S. Healthcare Reform and the Pharmaceutical Industry 15 (Harvard Bus. Sch., Working Paper No. 12-015, 2011), http://www.hbs.edu/faculty/ Publication\%20Files/12-015.pdf;; Alan M. Garber \& Jonathan Skinner, Is American Health Care Uniquely Inefficient? 22 J. ECON. PERSPECTIVES 27 (2008); Jill Quadagno, Interest-Group Influence on the Patient Protection and Affordability Act of 2010: Winners and Losers in the Health Care Reform Debate, 36 J. HeAlth POL. POL'Y \& L. 449, 449 (2011).

237 Jonathan Cohn, How They Did It, New Republic (May 21, 2010), http://www.newrepublic.com/article/75077/how-they-did-it. 
Moreover, to the extent these two high-profile pieces of legislation support the partisanship theory of the separation of powers-and they do to a point-they are atypical. Despite the presence of a super-majority during President Barack Obama's first year, there were few legislative accomplishments on policies aimed at reducing inequality or otherwise opposed by wealthy interests. This includes policies championed by the formal platform of the Democratic Party, the Obama campaign, and the Obama Administration. ${ }^{238}$ For example, President Obama campaigned on proposals to cap executive compensation, raise and index the minimum wage, and make the tax code more progressive. Yet proposals to rein in executive pay were "largely symbolic and fleeting, focused on companies that had taken bailout money and not yet repaid it"; ${ }^{239}$ and the minimum wage and tax reform went nowhere during the period of unified government. This was true even though these issues captured majority support in opinion polls, particularly from low- and middle-income voters. ${ }^{240}$ Of course, the absence of such legislation can be explained in part by a lack of time and resources; the government prioritized healthcare and financial reform and had little bandwidth for more. But that explanation circles back to the role of organized wealth: Part of why healthcare and financial reform occupied so much time was because of the political economy sketched above.

Systematic constraints and the shaping of debate by organized business interests are not a new phenomenon. Like the Obama Administration, recent prior Democratic administrations have rarely enacted legislation opposed staunchly by wealth, even during periods of unified government-and even after making campaign promises to prioritize such reforms. ${ }^{241}$ A look at the history of labor law reform

238 See 2008 Democratic Party Platform, The AmErican Presidency Project, http:/ /www.presidency.ucsb.edu/ws/?pid=78283 (last visited Oct. 2, 2015).

239 HACKER \& PIERSON, supra note 179, at 279. On the Obama legislative agenda and the role of lobbyists, see $i d$. at 278-85.

240 See BARTELS, supra note 192, at 230 (noting that in thirty-three different national surveys conducted between 1985 and 2006, support for increasing the minimum wage averaged $80 \%$ ); Frank Newport, Many Americans OK with Increasing Taxes on Rich, GALLUP (Apr. 25, 2008), http://www.gallup.com/poll/106813/many-americans-increasing-taxes-rich.aspx (noting that over half of Americans believed the government should redistribute wealth through heavy taxes on the rich); Lydia Saad, In U.S., $71 \%$ Back Raising Minimum Wage, GALLUP (Mar. 6, 2013) http://www.gallup.com/poll/160913/back-raising-minimumwage.aspx (describing majority support for minimum wage over time).

241 See GILENS, supra note 191, at 178-79, 193-96, 199-200 (showing that the unified Clinton years were more responsive to high-income preferences than to those of lower- and middle-income Americans); HACKER \& PIERSON, supra note 179, at 127-32, 278-79 (discussing such legislative failures during the Carter and Obama administrations). 
illustrates the point. The statute governing collective organization of workers-the National Labor Relations Act ("NLRA")—was enacted in 1935 and substantially amended in 1947 with the passage of the Taft-Hartley Act. Altered in minor ways with the Landrum-Griffin Act of 1959, the text of the statute has otherwise remained unchanged. ${ }^{242}$ On several occasions over the last thirty years, Democratic administrations, governing with Democratic Congresses, have offered major legislation to amend the NLRA.

The motivation for the continued attempts at law reform by Democrats is clear: While globalization and other exogenous factors help explain the decline of unions in this country, the governing legal regime is also an important cause of their weakness. Put bluntly, the NLRA, in its current form, fails to protect workers' ability to organize and bargain collectively with their employers. ${ }^{243}$ The law not only permits employers to express their opposition to unionization, it also recognizes their right to compel employees to listen to them in "captive audience" meetings and at the same time to exclude union representatives from the workplace, and it enables employers to use delay tactics aimed at suppressing organization. So, too, existing law fails to effectively prevent or punish coercive and illegal forms of employer opposition. The incidence of employer law-breaking has risen significantly since the $1970 \mathrm{~s} .{ }^{244}$

More fundamentally, the Act is mismatched with the structure of the contemporary economy. ${ }^{245}$ The statutory regime excludes from its coverage independent contractors, temporary workers, "knowledge" workers, and, to some extent, undocumented immigrant workers-precisely those workers that increasingly comprise the labor market. ${ }^{246}$ It effectively permits employers to exclude themselves from the definition of employer and the responsibility of bar-

242 Cynthia L. Estlund, The Ossification of American Labor Law, 102 COLum. L. REv. 1527, 153233 (2002).

243 To some extent, the failure of the governing statute to protect workers can be traced to early Supreme Court decisions that "deradicalized" the original Wagner Act and that reintroduced into the labor law many of the common law doctrines that the Act was meant to repudiate. See Karl E. Klare, Judicial Deradicalization of the Wagner Act and the Origins of Modern Legal Consciousness, 1937-1941, 62 MinN. L. REV. 265, 265-70 (1978). See also James B. Atleson, VAlues And Assumptions in American Labor LaW 9-10 (1983) (discussing early Supreme Court cases). Congress ultimately entrenched many of these decisions with the Taft-Hartley Act.

244 Estlund, supra note 242, at 1536-37.

245 See, e.g., KATHERINE V.W. STONE, From Widgets to Digits: EMPloyment Regulation FOR THE CHANGING WORKPLACE 119-21 (2004) (discussing how modern employment law's 1930s roots make it ill-suited for a digital workplace).

246 See 29 U.S.C. § 152 (defining "employer" and "employee"). 
gaining by contracting out their supply chains. ${ }^{247}$ And because American labor law has been centered in a single preemptive federal statute, with exclusive enforcement powers vested in a single federal agency, labor law has been insulated from other avenues of rejuvenation and reform, making federal statutory reform all the more necessary. ${ }^{248}$

Yet, despite the close alliance between the Democratic Party and the labor movement, Democratic controlled Congresses, under Democratic Presidents, have been responsible for three major legislative defeats for the labor movement since the 1970s-the period during which labor's organizational strength began to decline. ${ }^{249}$ In 1977, unions made a major labor law reform bill their top political priority. Large Democratic majorities in the House and Senate and a Democratic president initially committed support. ${ }^{250}$ But business interests energetically countermobilized and, although reform passed the House and commanded majority support in the Senate, the bill's opponents were able to sustain a filibuster by picking off a substantial number of Democrats. ${ }^{251}$ Labor law reform during the Clinton Administration met a similar fate, as business again mobilized against a further weakened labor movement. Pushing for a new social bargain, the Clinton Administration, through the vehicle of a high-profile commission, sought a reform package that would have eased restrictions on so-called company unions, while making it easier for workers to organize. ${ }^{252}$ But the deal collapsed even before the Republicans captured control of Congress in 1994, with the business community unwilling to countenance the renewed growth of trade unionism even in exchange for concessions that would have produced more flexibility for businesses. ${ }^{253}$ Again, in 2008, President Obama

247 But cf. Browning-Ferris Industries of California, Inc., 362 N.L.R.B. 186 (2015) (expanding the definition of "joint employer").

248 See generally James J. Brudney, Reflections on Group Action and the Law of the Workplace, 74 Tex. L. REv. 1563 (1996); Estlund, supra note 242, at 1527; Paul C. Weiler, Promises to Keep: Securing Workers' Rights to Self-Organization under the NLRA, 96 HARV. L. REV. 1769 (1983).

249 See HACKer \& Pierson, supra note 179, at 127-32 (discussing the political battles between the Carter Administration and business interest groups during the 1970s).

250 See, e.g., David Vogel, Fluctuating Fortunes: The Political Power of Business in AMERICA 148-50, 153 (1989) (analyzing the dynamic between organized labor and the Democratic Party after the 1976 election).

251 Id. at 150-51, 156 (discussing the circumstances that enabled a filibuster to oppose the bill).

252 See Nelson Lichtenstein, State of the Union: A Century of American Labor 245 (2002) (explaining the Clinton Administration's effort to revise labor law in order to ease the process of organizing labor unions). 
promised to reform labor law with the Employee Free Choice Act, which would have made it significantly easier for workers to unionize and would have required arbitration for first contracts. But after the Chamber and other wealthy and business interests targeted red state democrats, the bill died in a heavily Democratic Congress. ${ }^{254}$

In short, Congress has not enacted broad, redistributive labor law reforms even under unified governments that purport to support such reform. A similar story could be told about tax law ${ }^{255}$ and banking law, ${ }^{256}$ and little progress has been made on environmental law, given business opposition, even during unified Democratic government. ${ }^{257}$ This pattern does not show that the parties are equivalent, but it does demonstrate the need to revise constitutional theory's depiction of unified government. Wealth substantially constrains the actions that even a unified government can take.

\section{B. Divided Government and Gridlock}

Along with the growth in executive power, constitutional theorists worry about the decline of legislative power and the rise of gridlock. Congress today, many contend, is far more paralyzed than the Framers intended. The reason, theorists explain, is that "when combined with today's highly polarized political parties, veto points that once promoted bargaining and compromise now produce intransigence and gridlock." 258 Again, a bipartisan and trans-substantive account undergirds the story: Gridlock is near universal and the parties are to blame. ${ }^{259}$ In practice, however, gridlock is not a substantively neutral or consistently occurring phenomenon. Although partisanship is

254 HACKER \& PIERSON, supra note 179, at 278-79.

255 See generally Edward McCaffery, The Dirty Little Secret of (Estate) Tax Reform, 65 STAN. L. REv. ONLINE 21 (2012) (arguing that it is in Congress's interest financially to periodically review, yet do nothing, about tax reform).

256 See generally MCCARTY ET AL., supra note 187.

257 See HACKER \& PIERSON, supra note 179, at 279-80 (discussing the fate of climate change legislation in the early Obama Administration).

258 Jack M. Balkin, The Last Days of Disco: Why the American Political System Is Dysfunctional, 94 B.U. L. Rev. 1159, 1165 (2014). See also Mark Graber, Belling the Partisan Cats: Preliminary Thoughts on Identifying and Mending a Dysfunctional Constitutional Order, 94 B.U. L. REV. 611, 643-44 (2014) (arguing that the contemporary construction of political parties and the constitutional order leads to excessive blockage and dysfunction).

259 E.g., Freeman \& Spence, supra note 48, at 1-17 (discussing the current state of gridlock frustrating the administrative process in modern government); Levinson \& Pildes, supra note 9, at 2341 (explaining that divided governments are more prone to gridlock); Pozen, supra note 1, at 9 (identifying that the current political sphere is characterized by gridlock and disfunction). 
clearly part of the problem, it is an insufficient explanation for the most worrisome forms of gridlock.

That is, not all gridlock is equivalent from a constitutional governance perspective. Political inaction due to true and insurmountable policy disagreements between large pluralities may actually reflect popular will; political action due to equally powerful opposing forces that represent different sectors of the citizenry may follow the Madisonian schema of ambition counteracting ambition. Many examples of partisan gridlock are just that. ${ }^{260}$

But political inaction can also result when power is concentrated in few hands, without countervailing inputs. Wealth is an important source of this latter sort of gridlock. There are several reasons why. First, given our contemporary political economy, wealthy individuals and business organizations have the greatest capacity to create gridlock even when majorities support reform. ${ }^{261}$ Using the range of mechanisms detailed in Part II-from campaign donations to lobbying to aggressive engagement in the regulatory process-wealth has the resources to find and exploit veto points. And, as previously demonstrated, given contemporary American organizational life, countervailing forces are often lacking. ${ }^{262}$

Second, wealth also frequently has the greatest incentive to create gridlock because it has won at an earlier iteration of the process. That is, the status quo reflects the distribution of power in previous rounds of the policy process. ${ }^{263}$ Because the status quo reflects the outcome of prior power dynamics, often with "much greater benefits going to the privileged and the wealthy than to the needy and the poor," changes to the equilibrium tend to reflect changes to the mobilization of wealth. ${ }^{264}$ And research suggests that the greatest success

260 Josh Chafetz, for example, takes issue with the normative aspects of the separation-ofparties theory - the sometimes explicit, sometimes implicit, assertion that partisanship's effect on governance is something to be concerned about. As he points out, "it would seem to be a democratic feature of the system, not a bug, that the institutional checks on that party's ability to enact its agenda are weaker." Josh Chafetz, The Phenomenology of Gridlock, 88 NOTRE DAME L. REV. 2065, 2076-77 n.66 (2013) (arguing that unified versus divided government should be understood as "dependent ... on the will of the people, as expressed through electoral mechanisms"). Accord Josh Chafetz, Multiplicity in Federalism and the Separation of Powers, 120 YALE L.J. 1084, 1124 n.242 (2011) (explaining that a unified government may more effectively express the will of the people).

See supra notes 14-16 and accompanying text.

See supra note 88-90 and accompanying text.

BAUMGARTNER ET AL., supra note 203, at 19-20, 22-23, 240.

Id. at 23. 
of paid lobbyists occurs when they seek to protect the status quo from a proposed change. ${ }^{265}$

Finally, the wealthy also have the most power over the changing market conditions in which law intervenes. That is, legal stasis does not preclude wealthy interests, particularly large business organizations, from obtaining actual change through private ordering. When government fails to amend formal rules in the face of changed social and economic conditions, the result is distinct from preservation of the status quo. Political scientists Jacob Hacker, Paul Pierson, and Kathleen Thelan term this kind of gridlock "drift." 266 It occurs when the circumstances around policies or institutions change in ways that alter the effects of those policies or institutions on the ground, such that they no longer serve their intended purposes. ${ }^{267}$ Yet, alternative rules would reduce the degree to which these shifts in outcomes occur. $^{268}$ In other words, the shifts are potentially remediable, but efforts to update the rules fail. Business interests typically cause and benefit most from this form of gridlock. ${ }^{269}$

Federal wage law illustrates the point. Congress has failed to increase the minimum wage since 2007. At first glance, this looks like policy stasis. But because the cost of living has increased steadily, in real terms, minimum wages have declined. Policy has changed through drift. Moreover, the failure to amend federal minimum wage law has occurred not because of a deeply divided population represented adequately by warring political parties or branches. Opinion polls regularly reflect widespread support for minimum wage increases. ${ }^{270}$ Rather, gridlock in this context has occurred because certain segments of organized business and other wealthy

265 Id. at $147,236$.

266 Jacob S. Hacker et al., Drift and Conversion: Hidden Faces of Institutional Change, in ADVANCES IN COMPARATIVE-Historical ANALYSIS 180 (James Mahoney \& Kathleen Thelen eds., 2015).

$267 I d$.

268 Id. at $190-91$.

269 Hacker \& Pierson, supra note 90, at 191 (describing "a clear and important example of drift-where organized political action effectively prevents the updating of policy in response to changing market outcomes that were advantageous to the wealthy and powerful").

270 Press Release, Pew Research Center, Most See Inequality Growing, but Partisans Differ over Solutions 3 (Jan. 23, 2014), http://www.people-press.org/files/legacy-pdf/1-23-14\% 20Poverty_Inequality\%20Release.pdf (citing a national survey which reported that "73\% of the public favors raising the federal minimum wage from its current level of $\$ 7.25$ an hour to $\$ 10.10$ an hour"); Andrew Dugan, Most Americans for Raising Minimum Wage, GALLUP (Nov. 11, 2013), http://www.gallup.com/poll/165794/americans-raisingminimum-wage.aspx (reporting that "more than three-quarters of Americans (76\%) say they would vote for raising the minimum wage to $\$ 9$ per hour"). 
stakeholders have been able to influence key veto points in Congress and in the political parties. Through the mechanisms discussed in Part II, wealth has influenced enough members of both parties and both political branches to stop policy change. Moreover, wealthy interests have not only helped bring about federal paralysis on the minimum wage, but business interests have also benefited most from policy stasis. There are structural reasons why this is so: Because employers wield greater market power over employment conditions than do low-wage workers, they need not obtain legislative reforms to achieve policy goals; they can impose them through private ordering.

The NLRA provides another example: As described above, more than fifty years have passed without any significant statutory change in the NLRA. ${ }^{271}$ At first glance, this looks like a story of balanced partisan gridlock, i.e., of warring interest groups aligned with warring political parties, neither with sufficient power to enact change. On that view, this is a separation of powers success: Ambition has been made to counteract ambition. In fact, however, the story is more complicated. Business interests have been able to achieve change without statutory reform. Through tactics such as outsourcing, subcontracting, and globalizing, they have altered on-the-ground conditions of employment structures. Of course, businesses may have multiple motivations for such restructuring; nonetheless, one effect is to render the labor law largely impotent. ${ }^{272}$ Cynthia Estlund recounts,

The proof is in the political process: While organized labor has mounted several major efforts at labor law reform in the past thirty years, employers-equipped though they are with all of the political advantages of organization, internal unity, access, and wealth-have made almost no such efforts since 1959. For the most part, employers who oppose unions and collective bargaining are willing to bide their time in the political process, batting down periodic reform proposals that might tip the scales in unions' favor, and watching union strength ebb away.

Similar stories could be told about a host of other policy areas. Consider environmental law. The Toxic Substances Control Act ("TSCA") was passed in 1976 in order "to regulate chemical substances and mixtures which present an unreasonable risk of injury to

271 See Estlund, supra note 242, at 1535 ("The text of the NLRA has remained virtually untouched since 1959."); see also supra notes 242-54 and accompanying text.

272 See David Weil, The Fissured WORKPlace: Why Work Became So Bad For So Many ANd What CAN Be Done to Improve IT 17-18 (2014) (explaining that fissured workplaces enable companies to circumvent labor laws); Craig Becker, Labor Law Outside the Employment Relation, 74 TEX. L. REv. 1527, 1535 (1996) (explaining that subcontracting allows for businesses to circumvent traditional employment laws). 
health or the environment." ${ }^{274}$ Yet after years of rapid technological advancement, the Act, according to the EPA, is now outdated and fails to regulate many potentially dangerous substances. ${ }^{275}$ When efforts at modernization stalled in 2012, business groups rejoiced; one industry-oriented blogger wrote, "gridlock promises to be the best solution to a heated debate concerning legislation to reform the federal law dealing with chemicals." 276

In short, legal theorists and popular commentators are clearly correct in identifying partisanship as an important cause of gridlock. But in focusing on partisanship alone, they miss key ways in which gridlock varies by issue and in effect. Given the contemporary political economy, gridlock is not merely a problem of the parties. Rather, wealth has both unmatched capacity and incentive to bring about gridlock.

\section{Administrative Checks}

Of course, divided government brings not only gridlock but also presidents and agencies with incentives to push the bounds of formal power. Faced with intransigent legislatures from the opposing party, hyper-partisan presidents have found new tools to set policy unilaterally, without congressional approval. ${ }^{277}$ Presidents use direct methods, such as executive orders, presidential memoranda, and signing statements. They also act indirectly, pressing executive branch agencies to advance the Administration's policy agendas through rulemaking, waivers, guidance policy, enforcement efforts and so on. ${ }^{278}$ At the same time, internal separation-of-powers scholars emphasize, a host of non-partisan bureaucratic checks constrain such executive ac-

274 Toxic Substances Control Act, 15 U.S.C. \$ 2601 (b) (2) (1976).

275 Elizabeth Grossman, What the EPA's "Chemicals of Concern" Plans Really Mean, SCIENTIFIC AMERICAN (Jan. 11, 2010), http://www.scientificamerican.com/article/epa-chemicals-ofconcern-plans/ (reporting that, in late 2009, EPA spokesperson Ernesta Jones expressed the "EPA's strong belief that the 1976 law is both outdated and in need of reform").

276 Angela Logomasini, When Gridlock Is Good: The Case Of The Toxic Substances Control Act, COMPETITIVE ENTERPRISE INSTITUTE (Dec. 6, 2012), https://cei.org/blog/when-gridlockgood-case-toxic-substances-control-act.

277 See HowELL, supra note 223, at 179 (studying the rise of various means of direct presidential action and explaining that, "[w] hile it was relatively rare, and for the most part inconsequential, during the eighteenth and nineteenth centuries, unilateral policy making has become an integral feature of the modern presidency."). See also Kagan, supra note 53, at 2281-2303 (chronicling use of unilateral power during Clinton presidency); Kate Andrias, The President's Enforcement Power, 88 N.Y.U. L. REv. 1031, 1069-71 (exploring rising use of enforcement as unilateral policy tool).

278 HowELL, supra note 223, at 13-14 (identifying how presidents can advance their policy agendas through persuasion and indirect methods). 
tion. $^{279}$ Thus, according to the dominant narrative, across domains, the President's use of unilateral power is at once extensive and checked from within.

While the above story is, in broad strokes, unassailable, it is also incomplete. Again, the problem is that the account is undifferentiated: it implies that the use of unilateral power is robust and hyperpartisan, no matter what the issue, and that the internal bureaucracy serves as a neutral, effective check irrespective of substantive content. It largely fails to consider circumstances where this is not the case. Yet, as with gridlock, unilateral executive power and internal bureaucratic checks are shaped fundamentally by wealth. Because of their systematic influence, economic elites, large businesses, and their organizations define both unilateral presidential action and internal checks on many issues.

Consider executive orders. The partisanship model teaches that, in this highly ideologically polarized environment, presidents use executive orders to pursue hyper-partisan agendas. The implication of this theory is that, when government divided in 2010, the Democratic President should have issued executive orders to advance liberal policies not achievable in Congress. Indeed, on a host of salient issues President Obama moved forward quickly with aggressive executive actions. The most striking examples were the decision not to defend the Defense of Marriage Act and to use enforcement discretion to benefit immigrant children through Deferred Action for Childhood Arrivals. These were aggressive and partisan uses of executive power that polarized the electorate. But both policies were also highly salient and had little opposition from business interests or economic elites more generally.

In contrast, the President's labor-related executive ordersincluding those that aim to raise the minimum wage for executive branch contracts and impose penalties on contracting employers with labor and employment violations-were issued a full six years after

279 See supra notes $10-11$.

280 Indeed, leading business executives and the Chamber of Commerce advocated immigration reform. See Sheldon Adelson, Warren Buffett \& Bill Gates, Op-Ed., Break the Immigration Impasse, N.Y. Times, July 11, 2014, at A25 (showing three business executives publicly advocating for an immigration reform bill); Ashley Parker, Business-Conservative Alliance Presses for Immigration Action, N.Y. TIMES, Oct. 30, 2013, at A16 (reporting on a large group of business executives advocating to politicians for immigration reform in an event sponsored by the Chamber of Commerce). More than 200 companies, including Citigroup, Apple, Mars and Alcoa, publicly urged the Supreme Court to overturn the Defense of Marriage Act. Erik Eckholm, In Gay Marriage Brief, A Corporate Call for Change, N.Y. TIMES, Feb. 28, 2013, at B1. 
partisan supporters called for such action. These orders, like the others, had strong support from the party's base. And as a formal legal matter, they were no more aggressive than the gay rights and immigration orders. The D.C. Circuit has interpreted liberally the President's authority to implement the contracting law including through imposition of employment-related requirements. ${ }^{281}$

Given the strong support for a minimum wage hike and basic employment rights among the Democratic base, the separation-of-parties theory would suggest that there should have been a quick issuance of pro-worker executive orders. Yet the orders were strenuously opposed by the business community and they faced bipartisan inter- and intra-branch opposition. That is, members of Congress and bureaucratic officials with long-term relationships with the contracting community repeatedly sought to squelch the orders. ${ }^{282}$ Ultimately, the labor executive orders were issued only after significant countervailing forces mobilized: federally contracted workers repeatedly went on strike calling attention to their poverty wages, as did workers in other low-wage industries, most notably fast food. ${ }^{283}$ Meanwhile, popular concern and commentary about economic inequality mounted.

It should not be surprising that presidential unilateralism has been cautious on issues opposed by business interests. Recall the many ways Presidents and their White Houses confront wealth. But there is considerable tension between this account and the picture of an unbound and hyper-polarized president. In short, an examination

281 See, e.g., UAW-Labor Employment \& Training Corp. v. Chao, 325 F.3d 360, 366 (D.C. Cir. 2003) (emphasizing "the necessary flexibility and "broad-ranging authority" given to the President by the procurement Act); AFL-CIO v. Carmen, 669 F.2d 815, 825 (D.C. Cir. 1981) (holding that the President's executive action to place a parking charge on federal employee parking spaces falls within authority granted by Congress); AFL-CIO v. Kahn, 618 F.2d 784, 788, 796 (D.C. Cir. 1979) (en banc) (upholding the President's executive action to establish wage and price standards for executive agencies); Contractors Ass'n of Eastern Pennsylvania v. Sec. of Labor, 442 F.2d 159, 162-63, 174 (3d Cir. 1971) (upholding an executive action that required construction companies to submit affirmative action plans).

282 Steven Greenhouse, Plan to Seek Use of U.S. Contracts as a Wage Lever, N.Y. TimES, Feb. 26, 2010, at A1. Cf. Josh Eidelson, Federal Workers to Strike, March on White House Wedneday, SALON (Sept. 24, 2013) http://www.salon.com/2013/09/24/federal_workers_to_strike_ march_on_white_house_wednesday/ (noting, in 2013, that a "high road" contracting policy that would have offered companies with higher standards a leg up in securing contracts, was under consideration by the administration in 2010, but "never came to pass").

283 See, e.g., Elena Schneider, Food Services Workers Strike, N.Y. TIMEs, Nov. 14, 2014, at A14 (reporting on strikes by hundreds of federally contracted food service workers); Steven Greenhouse, Fast-Food Workers Seeking $\$ 15$ Wage Plan Civil Disobedience at Strikes, N.Y. TIMES, Sept. 2, 2014, at B3 (reporting on nationwide strikes of fast-food workers calling for wages to increase to $\$ 15$ ). 
of presidential actions in light of political economy leads to a more complicated picture of unilateralism than that depicted in the literature.

When one considers agency action-and the mechanisms of internal separations of power-the impact of money becomes even more evident: When government does act contrary to organized wealth, attention shifts to the less visible administrative process.

Return to financial regulatory reform. Despite the broad reach and several thousand pages of the Dodd-Frank Act, few of its provisions took effect in the summer of 2010. Instead, the details of the Act were left for the federal rulemaking process. ${ }^{284}$ That process has been overwhelmingly dominated by the financial services industry, with regulators meeting regularly with representatives from big banks and banking associations, and much less often with consumer and pro-reform groups. ${ }^{285}$ The amount of money spent by Wall Street on persuading regulators and members of Congress during this period also far dwarfed countervailing resources. ${ }^{286}$ Meanwhile, the banking industry provided campaign donations to both Republican and Democratic members who had capacity to influence rulemakers. ${ }^{287}$

284 Tarbert, supra note 227, at 373 (explaining that the Dodd-Frank Act left most of the rulemaking responsibility to administrative agencies in the years subsequent to the Act's passage).

285 During the year following the passage of the Dodd-Frank Act, regulators at the three major banking regulatory agencies-the Treasury, the Fed, and the Commodities Futures Trading Commission ("CFTC")—reported meeting with twenty big banks and banking associations on average a combined 12.5 times per week. That compares to just 2.3 meetings with reform-oriented groups on average per week. The top twenty banks appear 1,298 times in meeting logs at the three agencies, while groups favoring tighter regulations of the financial markets show up just 242 times. Lee Drutman, Big Banks Dominate Dodd-Frank meetings with regulators, SUNLIGHT FOUNDATION BLOG (July 19, 2012, 4:00 AM) http://sunlightfoundation.com/blog/2012/07/19/dodd-frank-two-years-later/. The gap widened following the first year. With regulators increasingly focused on more technical rules (e.g., swap exchange facilities, position limits, proprietary trading), regulators met 560 times with the big banks in 2012, but just eighty-one times with reform groups. And during the first year of rulemaking, regulators met 738 times with the big banks as compared to 161 meetings with the reform groups. Id. See also Nancy Watzman, Ex Post Facto Lobbying: Banks Blitz Regulators to Soften Dodd-Frank's Impact, SUNLIGHT FOUNDATION BLOG (Jul. 22, 2013, 10:24 AM), http://sunlightfoundation.com/blog/2013/07/22/crossborder-lobbying/ (highlighting the number of financial industries met with compared to reform-oriented groups in the weeks leading up to a Dodd-Frank Act reform deadline).

286 See Ben Protess, Wall Street Continues to Spend Big on Lobbying, N.Y. Times DEALBook (Aug. 1, 2011, 2:33 PM), http://dealbook.nytimes.com/2011/08/01/wall-street-continues-tospend-big-on-lobbying/ (reporting the vast amount of wealth spent by financial lobbyists in the wake of Dodd-Frank).

287 Lipton \& Protess, supra note 234 (reporting on the heavy lobbying by financial institutions directed at politicians in both major parties). 
Meetings and money, of course, do not prove influence. But as the broader studies discussed in Part II indicate, organized wealth has long been successful at moderating the implementation of statutes through a host of interrelated tactics. And, indeed, the progress of financial regulatory reform to date suggests that the lobbying by, and contributions from, the financial industry have been at least partially effective. At the two-year anniversary date, the deadlines for more than half of the required rulemakings had expired and regulators had finalized rules for only one-third of those rulemakings with statutory dates, missing the deadlines for the rest. ${ }^{288}$ Sheila Bair, who was appointed to head the Federal Deposit Insurance Corporation by George W. Bush in 2006 and served in that role until 2011, placed the blame for regulatory inaction on the resistance to reform posed by an industry with hundreds of lobbyists and hundreds of millions of dollars to spend: "At the end of the day, the regulators are outgunned." 289 One striking example of the strength of industry lobbyists is the evolution of the "de minimis exception" to the requirement that dealers selling derivatives register with the CFTC. The original proposal was that when a dealer's annual revenue from credit default swaps topped $\$ 100$ million, it would have to register and comply with a regulatory regime. After the industry weighed in-at the behest of smaller but still wealthy and well-organized financial players-the exemption was inflated dramatically: the 2013 final rule set a threshold of $\$ 8$ billion, which would shrink to $\$ 3$ billion after three years. ${ }^{290}$

While individual legislators sometimes oppose industry's influence in the regulatory process, there is little reason to think that Congress consistently counteracts business' influence. Indeed, the existing data suggests Congress rarely intervenes on behalf of any diffuse public interest against industry interests. ${ }^{291}$ For example, during recent financial regulatory hearings, "most of the Democrats on the committee, along with 31 Republicans, came to the industry's defense, including the seven freshmen Democrats-most of whom have started to receive donations this year from political action committees of Goldman Sachs, Wells Fargo and other financial institutions, records

\footnotetext{
288 Tarbert, supra note 227, at 373.

289 Gary Rivlin, Wall Street Fires Back, The NATION, May 20, 2013, at 11, 12, 14 (noting commercial banks such as Wells Fargo, Citigroup and JP Morgan Chase, along with their trade groups, spent $\$ 55$ million lobbying in 2010, the year Dodd-Frank became law, $\$ 61$ million in 2011 and another $\$ 61$ million in 2012).

$290 \quad I d$. at 22; 17 C.F.R. $\$ 240.3 \mathrm{a} 71-2$ (2013).

291 See Wagner et al., supra note 211, at 137 n.128, 142 (examining congressional intervention in context of EPA rulemakings).
} 
show." ${ }^{292}$ The literature also provides little to no support for the possibility that the President or the Office of Management and Budget ("OMB") regularly intervenes to make agency rules more protective of the public interest and less protective of business, particularly once the issue is no longer salient. To the contrary, the available evidence suggests that White House and OMB review, in the aggregate, further favors industry. ${ }^{293}$

And there are countless other areas of administration where the influence of concentrated wealth has systematically checked and prodded the internal bureaucracy, without effective checks or inputs from the countervailing organization or the vast majority of Americans. ${ }^{294}$ Environmental regulation and trade policy are two other striking examples. ${ }^{295}$

Certainly, unilateral executive action does not always favor business interests. As the above discussion demonstrates, the checks and prods imposed by wealthy individuals and organizations are weaker when issues are highly salient and countervailing organizations act in opposition. $^{296}$ Furthermore, agencies do not typically neglect their missions altogether even when they are pushed by business interests or adjust course in response to those interests. ${ }^{297}$ But while the effect of wealth on internal administrative checks is neither simple nor linear, it is systematic.

293 For example, recent studies of OMB identify a distinct anti-environmental bent that is consistent across administrations. See Wagner, supra note 211, at $151 \mathrm{n} .166$ (summarizing OMB studies from the Bush I and Clinton Administrations that analyzed the impact of regulation on industry).

294 For another example involving the financial sector, see Tara Siegel Bernard, Brokers Fight Rule to Favor Best Interests of Customers, N.Y. TIMES, June 13, 2014, at B1, B7 ("Amid fierce pushback from the financial services industry, the Labor Department, which oversees retirement plans, recently delayed releasing a revised proposal that would require a broader group of professionals to put their clients' interest ahead of their own when dealing with retirement accounts.").

295 See, e.g., Robert E. Baldwin \& Christopher S. Magee, Is Trade Policy for Sale? Congressional Voting on Recent Trade Bills (Nat'l Bureau of Econ. Research, Working Paper No. 6376, 1998), http://www.nber.org/papers/w6376.pdf (finding that business influence affected legislators' votes on NAFTA and GATT); Michael E. Kraft \& Sheldon Kamieniecki, Analyzing the Role of Business in Environmental Policy, in Business AND ENVIRONMENTAL Policy: Corporate Interests in the American Political System 3-4 (Michael E. Kraft \& Sheldon Kamieniecki eds., 2007).

296 See supra notes 142, 158-59, 280-82 and accompanying text.

297 See Carpenter \& Moss, supra note 166, at 12 (arguing that even when regulatory capture exists, it is limited). 


\section{ORGANIZED WEALTH AND THE FUNCTIONS OF CONSTITUTIONAL STRUCTURE}

Thus far, the project of this Article has been largely descriptive and critical: wealth systematically checks the branches and the parties in ways that complicate a partisanship focused account. This Part shifts to a normative analysis. It asks how the dominance of wealth advances or impedes attainment of the functional goals of the separation of powers - as understood by contemporary scholars-and concludes that democratic accountability is severely injured. It then considers what should be done in response.

\section{A. Functions of Constitutional Structure}

Legal scholars and judges-at least those who embrace a functional, rather than formal, approach to the separation of powersfocus on several overarching goals of our separation of powers. These include preserving liberty, promoting governmental efficacy, and enhancing democratic accountability, all through diffusing political power. ${ }^{298}$ Scholars focusing on partisanship and internal checks embrace these goals as well. ${ }^{299}$ Given the limitations of inter-branch political competition in practice, they argue, political parties and internal executive branch checks provide an alternate way to achieve or undermine these functional goals. ${ }^{300}$ But how does wealth shape the ability of the branches, parties, and internal checks to achieve these goals?

\section{Liberty}

In the conventional telling, liberty is a central aim of the separation of powers. By dividing functions among the three branches and enabling the various branches to check one another, the theory runs,

See, e.g., Bruce Ackerman, The New Separation of Powers, 113 HARV. L. REV. 633, 640 (2000) (describing goals as protecting fundamental rights, advancing democracy, and enhancing professional competence); Martin S. Flaherty, The Most Dangerous Branch, 105 YALE L.J. 1725, 1729-30 (1996) (describing separation of powers goals as balance, accountability, and energetic, efficient government); Magill, supra note 131, at 1148-52, 1148 n.80 (2000) (arguing that formalists and functionalists agree on an intermediate goal of separation of powers: to prevent a single branch of government from possessing and using too much power). Historical accounts of the founding are largely in accord. See, e.g., GWYN, supra note 73, at 127-28.

299 See, e.g., Metzger, supra note 10, at 428 (describing the ultimate goal of separation of powers as dispersing federal power across three branches to prohibit tyranny while creating an effective and accountable National government).

300 See supra notes 9-11; see also infra notes 304, 308, 314-15 and accompanying text. 
the Framers sought to reduce "the amount of damage to liberty or other interests that any fallible or corrupt official might be able to inflict." 301 According to some commentators, hyper-polarization and the related growth of the executive branch at the expense of Congress threatens this promise. ${ }^{302}$ On this account, the over-empowered Executive directs vast domestic and national security programs, and is virtually unchecked even when government actions threaten individual liberty interests.

For such critics of executive power, the political economy sketched above could assuage concerns, at least insofar as the particular executive actions in question implicate market and business interests. As discussed in Part III.A, even during periods of unified government when the partisanship theory predicts legislative and executive collusion, wealth, particularly business organizations, functions to moderate and limit government action. Indeed, when there are opposing interests within the business community, as is often the case, potential government intrusions on liberty interests decrease further; it becomes difficult for any one particular interest group within the category of wealthy interests to propel government action past multiple veto gates. And in times of divided government, when the executive may attempt to push the boundaries of formal power, wealth often has sufficient influence throughout the bureaucracy and the White House to provide a check where one otherwise may be lacking. ${ }^{303}$

Yet in other important ways, money in governance operates at cross-purposes with liberty goals: Wealth can overwhelm internal executive branch mechanisms designed to protect individual fairness and due process. For example, within agencies, the separation of adjudication from legislative, investigatory, and enforcement activities aims to promote due process, while the civil service is designed to depoliticize governmental administration in order to ensure regularity

\footnotetext{
301 Jeremy Waldron, Separation of Powers in Thought and Practice? 54 B.C.L. REv. 433, 440 (2013). The notion is that, because branches independent of Congress would ultimately apply the law, legislators would have strong incentives to define punishable misconduct with precision and moderation, thereby benefiting all citizens, whether friends of Congress or not. AKhil Amar, America's Constitution: A Biography 63 (2005). See also Rebecca L. Brown, Separated Powers and Ordered Liberty, 139 U. PA. L. REv. 1513, 1515-16, 1530-31 (1991) (arguing that the primary separation of powers goal is to protect individual rights against encroachment by a tyrannical majority).

302 E.g., ACKerman, supra note 3, at 15-16; SHANE, supra note 221, at vii. Cf. Levinson \& Pildes, supra note 9, at 2350, 2354-55.

303 See supra Part III.C.
} 
and the rule of law. ${ }^{304}$ Wealth's systematic influence over these internal mechanisms weakens their ability to deliver on that promise. ${ }^{305}$ Perhaps more importantly, the notion that minimizing government action necessarily promotes liberty, particularly in the economic sphere, rests on a Lochnerian vision of individual freedom. ${ }^{306}$ Should one reject that view, recognizing that government inaction often allows for private invasions of liberty interests or, more fundamentally, that market ordering is itself a legal construct, the argument for organized wealth's political checks would further weaken.

\section{Efficacy}

While the separation of powers is often thought of as a way to check government action, the division of governmental functions can also serve to promote effective government. Indeed, scholars have argued that our constitutional structure is aimed not only at checking government action, but also at establishing productive and energetic government, a break from the national experience under the Articles of Confederation. ${ }^{307}$ The idea is that by engendering competition among and between the branches, government actors can be stirred to act. ${ }^{308}$ And by enabling each branch to concentrate on a different function, expertise can flourish. ${ }^{309}$ Our constitutional structure thus seeks to facilitate necessary action and to increase the efficacy of government. ${ }^{310}$

A common refrain in the literature and commentary on constitutional dysfunction is that hyper-polarization has impeded governmental energy and efficacy. Because of partisan divides, the branches do not stir one another to act, but rather remain locked in opposition. ${ }^{311}$ According to more recent work, the problem is not just polarization but fragmentation. Because contemporary parties are fragmented

Metzger, supra note 10, at 429-30.

See supra Part III.C.

See Lochner v. New York, 198 U.S. 45 (1905). For one such critique of Lochner and its reliance on common law baselines, see Cass R. Sunstein, Lochner's Legacy, 87 CoLum. L. REV. 873, 875 (1987).

See Loving v. United States, 517 U.S. 748, 757 (1996) (noting that by "allocating specific powers and responsibilities to a branch fitted to the task," the Framers created a national government that is "effective"). AMAR, supra note 301, at 64; ARENDT, supra note 36, at 152-55 (discussing Montesquieu and Founders' incorporation of his theories).

Levinson \& Pildes, supra note 9, at 2312; Waldron, supra note 301, at 440.

AMAR, supra note 301, at 64 .

See Ewing \& Kysar, supra note 24, at 366-67 (emphasizing the capacity of divided authorities to push each other to action when changing social conditions require it).

See, e.g., Pildes, supra note 2, at 330-31. 
and decentralized, the parties' formal leaders, who should have the most incentive to compromise, struggle to control other members. ${ }^{312}$

To these critics of contemporary political partisanship, there is a positive story to tell about the effects of wealth on Congress. Through the mechanisms discussed in Parts I and II, wealth mitigates polarization on important issues. Wealth exerts substantial influence over both parties, ensuring that key segments of each support their positions. Thus, in practice, compromises are often more likely to be reached when government action is essential for business interests.

Whether this phenomenon is something to celebrate, however, is contestable. The answer depends in large part on one's policy perspective and estimation of the compromises reached. Moreover, government action produced by wealth's influence over both parties may be in tension with the third functional goal of separation of powers: democratic accountability. That is, such action may not be reflective of majority viewpoints, and may sometimes be more aptly described as capture than compromise. ${ }^{313}$

Finally, and most important, just as wealth can help narrow the gap between the political parties in order to promote governmental action, wealth also prevents action where legislators across partisan divides might otherwise agree. As Part III.B discussed, business interests often have particular ability to affect gridlock: Campaign donations, lobbying, personal connections, the revolving door, expertise over technical issues, and other mechanisms enable wealth to exercise influence over various veto points in the legislative process, and thereby to block incipient action. And business interests have particular incentive to affect gridlock: They are able to exercise significant control over the market conditions in which law attempts to intervene, making legislative change less appealing.

Within the executive branch, a similarly mixed picture of the relationship between wealth and governmental efficacy emerges. Scholars who study the administrative state often emphasize its ability to produce energetic and effective government: In an era of polarization and gridlock, when the inter-branch system fails, executive branch agencies continue to innovate and govern. ${ }^{314}$ According to these scholars, internal separations and checks encourage inter-

312 See Pildes, supra note 2, at 333 (explaining that the extreme polarization of political parties has damaging, and seemingly irreversible consequences).

313 See supra Part III.C (discussing role of organized wealth in regulatory and administrative process).

314 See Barron \& Rakoff, supra note 48, at 260; Freeman \& Spence, supra note 48, at 7; Kagan, supra note 53, at 2344. 
agency competition and the development of expertise, both of which enhance governmental productivity. ${ }^{315}$

Checks and prods by wealthy interests sometimes enhance this dynamic. Business groups can be instrumental in pushing agencies to innovate. They also can provide important information throughout the regulatory process, enhancing expertise. On the other hand, organized wealth is just as likely, if not more so, to stall regulation. ${ }^{316}$ Indeed, even when one part of an agency innovates through new regulatory or enforcement tools, business groups often find ways to check the putative policies before they are enacted or to challenge them once implemented. ${ }^{317}$

\section{Democratic Accountability}

The third function attributed to our constitutional structure by both the Court and contemporary theorists is that of furthering democratic accountability. ${ }^{318}$ According to numerous scholars, the Founders sought to create a government influenced by, and in service of, the citizenry generally-as opposed to a regime by and for "the cabals of a few." ${ }^{319}$ Separating powers across branches was one way to achieve this goal. By establishing multiple centers of recourse, many places to which citizens can appeal when they are not receiving satisfaction from other centers of government, government becomes more responsive and accountable, while still respecting liberty interests. $^{320}$ Because each government entity is selected in a different way by a different constituency, government policy, the theory runs, is more likely to reflect multiple indices of popular sentiment. ${ }^{321}$ And while a faction might be able to capture one branch, it is less likely to acquire power over all three. ${ }^{322}$

\footnotetext{
315 See, e.g., Jody Freeman \& Jim Rossi, Agency Coordination in Shared Regulatory Space, 125 HARV. L. REV. 1131, 1150-51 (2012) (discussing benefits and drawbacks of inter-agency coordination); Metzger, supra note 10 , at 425 (analyzing what types of administrative structures are likely to prove effective at checking executive power).

316 See supra Part III.B \& notes 284-95 and accompanying text.

317 See notes 284-95, 345-47 and accompanying text.

318 See Loving v. United States, 517 U.S. 748, 757 (1996) (emphasizing accountability, along with efficacy, as a separation-of-powers goal). For descriptions of accountability as a core separation of powers value, see Steven G. Calabresi, Some Normative Arguments for the Unitary Executive, 48 ARK. L. REV. 23, 42-45 (1995) and Lessig \& Sunstein, supra note 220, at 94.

319 The FEDERALIST No. 10, supra note 60, at 82.

320 See AMAR, supra note 301, at 64 (discussing how separation of powers has allowed each branch to become specialized). 
Scholars who focus on alternate mechanisms of political competition emphasize democratic accountability as well. For example, internal separation-of-powers scholars contend that the separation of functions within agencies and the presence of multiple loci of appeal within the administrative state help preserve the accountability of the bureaucracy, while making capture more difficult. ${ }^{323}$

It is not inconceivable that the political economy described above could be construed as consistent with a vision of democratically accountable government. Indeed, the current majority of the Court has so argued. According to Chief Justice John Roberts, writing for the majority in McCutcheon v. FEC, removing limits on campaign contributions allows those persons (natural or otherwise) who care the most about issues to organize effectively and make their views heard. ${ }^{324}$ On this view, systematic checks and prods by wealthy individuals and business organizations help conform government action to the views of those who care enough to get involved.

On the other hand-and I think this is the correct view-wealth's disproportionate influence at every step of the political and governing process and the lack of effective countervailing participation mean that government leaders often fail to consider, and government action often fails to reflect, the views and interests of the vast majority of Americans. Instead, government hears from and responds to the interests of a particular faction. As a result, the democratic accountability promised by inter-branch competition, as well as by alternative mechanisms of political competition, is missing. And one need not settle on a single theory of democratic accountability to conclude that capture by faction is inconsistent with the ideal. ${ }^{325}$

At the most fundamental level, our constitutional structure aims to preserve republican government and protect the citizens from the emergence of tyranny "by establishing multiple heads of authority in government, which are then pitted one against another in a continu-

323 See Metzger, supra note 10, at 457 (concluding that maintaining executive branch accountability through congressional enactments reinforces the importance of separation of powers in "the contemporary world of administrative governance").

324134 S. Ct. 1434, 1448 (2014). But see id. at 1462 ("Representatives are not to follow constituent orders, but can be expected to be cognizant of and responsive to those concerns. Such responsiveness is key to the very concept of self-governance through elected officials.”).

325 For one theory of representation, see HANNA FENICHEL Pitkin, THE CONCEPT OF REPRESENTATION 144-45 (1967) (highlighting that a delegate "must do what his principal would do, must act as if the principal himself were acting ... must vote as a majority of his constituents would"). 
ous struggle." ${ }^{326}$ As James Madison wrote long ago, "It is of great importance in a republic, not only to guard the society against the oppression of its rulers; but to guard one part of the society against the injustice of the other part." ${ }^{327}$ As the preceding section demonstrates, because of the pervasive influence of wealth across branches and parties, power is far less diffused than constitutional theory promises. The multiple heads of authority in government and in politics do not consistently perform the checking and prodding function anticipated, or at least do not do so in ways reflective of and accountable to the citizenry generally.

\section{B. Reforming Constitutional Law}

Wealth corrodes constitutional structure, leaving us with a government in which power is frequently not diffused and democratic responsiveness is undermined. What should be done? This section first considers the possibility of using greater judicial review of executive and legislative action to check the role of wealth. It ultimately concludes, however, that institutional design reform-namely reform aimed at building countervailing organization, as well as more familiar election law and lobbying reform-is more promising than an expanded role for the judiciary. Finally, it responds to critics who would argue that such reform is wholly impossible given the political economy described in this article.

\section{Enhanced Judicial Review}

One possible response to the power of wealth in politics and governance would be something akin to the tiered judicial scrutiny of executive action established by Justice Robert Jackson's famous concurrence in Youngstown Sheet and Tube Co. v. Sawyer. ${ }^{328}$ Or, more familiarly, the heightened scrutiny defended in United States v. Carolene Products' famous footnote four. ${ }^{329}$ Courts could impose more intense judicial review of legislative or executive action in circumstances where wealth has dominated without countervailing checks. For example, courts might impose greater scrutiny when wealthy interests

\footnotetext{
326 Strauss, supra note 13 , at 578.

327 THE FEDERALIST No. 51, supra note 60, at 323.

328343 U.S. 579, 635 (1952) (Jackson, J., concurring). Cf. Levinson \& Pildes, supra note 9, at 2353-54 (arguing for more intense judicial review of executive action, particularly in the national security context, to redress the absence of partisan checks during unified government).

329 United States v. Carolene Products Co., 304 U.S. 144, 152 n.4 (1938).
} 
have participated at disproportionate rates in the administrative process, or where a particular governmental action serves to further concentrate power among the wealthy. Conversely, where the executive acts to remediate the concentration of wealth or where the government effectively involves countervailing organizations in the governance process, more deference would be due.

Indeed, courts, for a time, sought to redress imbalances in interest group power in the context of administrative law cases. Beginning in the late 1960s, judges on the Court of Appeals for the District of Columbia made a concerted effort to consider the role of concentrated power in administrative law cases. ${ }^{330}$ In the view of these judges, the costs and dynamics of political organization meant that industry and other business interests were overrepresented. As a result, environmental, consumer, and other interests were due special solicitude. The judges thus fashioned new procedural rules that required agencies to offer more procedures than the Administrative Procedure Act ("APA") mandated. ${ }^{331}$ The D.C. Circuit essentially attempted a power diffusing project, in which the judicial role was heightened when countervailing checks were absent. ${ }^{332}$

The Supreme Court unanimously put an end to this approach in Vermont Yankee Nuclear Power Corp. v. Natural Resources Defense Council, Inc. ${ }^{333}$ Holding that hybrid procedural requirements had no basis in the APA, the Court emphasized that in reviewing agency rules, judges should "not stray beyond the judicial province to explore the procedural format or to impose upon the agency its own notion of which procedures are 'best' or most likely to further some vague, undefined public good." "334

330 See, e.g., Home Box Office, Inc. v. FCC, 567 F.2d 9, 53 (D.C. Cir. 1977), cert. denied, 434 U.S. 829 , reh'g denied, 434 U.S. 988 (1977) (“[W]e are particularly concerned that the final shaping of the rules we are reviewing here may have been by compromise among contending industry forces, rather than by exercise of the independent discretion in the public interest the Communications Act vests in individual commissioners."); MCI Telecomms. Corp. v. FCC, 561 F.2d 365, 380 (D.C. Cir. 1977) ("The ultimate test of industry structure in the communications common carrier field must be the public interest, not the private financial interests of those who have until now enjoyed the fruits of a de facto monopoly.").

331 For analysis of these developments, see Merrill, supra note 33, at 1050-52; Antonin Scalia, Vermont Yankee: The APA, the D.C. Circuit, and the Supreme Court, 1978 SuP. CT. Rev. 345, 348-56 (1978); Stewart, supra note 151, at 1711-60; Cass R. Sunstein \& Adrian Vermeule, Libertarian Administrative Law, 82 U. CHI. L. REV. 393, 394 (2015)

332 Bruce Ackerman has referred to this as a democracy-enhancing project. See Bruce Ackerman, Beyond Carolene Products, 98 HARV. L. REv. 713, 715 (1985).

333435 U.S. 519 (1978).

334 Id. at 549 (1978); see also id. at 524 ("[T] he [APA] established the maximum procedural requirements which Congress was willing to have the courts impose upon agencies in 
Outside of the APA context, however, judicially imposed heightened scrutiny is not foreclosed, for Vermont Yankee was an interpretation of the APA, not a general rejection of the use of judicial presumptions to counter-balance powerful interest groups. Indeed, in the 1980s, drawing on public choice theory, numerous scholars urged variations of this approach, albeit not from a separation-of-powers perspective. ${ }^{335}$ For example, courts could apply less scrutiny to executive orders or regulations designed to redress economic inequality or to protect the environment. The theory would be that those are the kinds of policies unable to pass Congress even in unified government due to the aggregation of power in the hands of wealthy individuals and business organizations. Conversely, when an executive order benefits a narrow and well-funded interest, and there are no countervailing checks, courts could follow Justice Jackson in tilting toward rejection of executive action, particularly when that action amounts to a novel expansion of executive power.

Such an approach finds support in existing case law. Following Vermont Yankee, lower courts have continued to worry about agency

conducting rulemaking procedures.... [R] eviewing courts are generally not free to impose [additional procedural requirements].”); Baltimore Gas \& Elec. Co. v. Natural Res. Def. Council, Inc., 462 U.S. 87, 97-98 (1983) (warning against overly stringent arbitrariness of judicial review).

335 Numerous scholars have used public choice theory to argue for heightened judicial review in the constitutional context. See, e.g., Martin Shapiro, Freedom of SPEech: The Supreme Court AND JUdicial REvieW 2, 17-25, 31-39 (1966) (arguing that, at least in the First Amendment area, the Court should not defer to a political process driven by interest group politics but rather should advance the cause of the groups the political process underrepresents); Erwin Chemerinsky, The Supreme Court, 1988 Term-Foreword: The Vanishing Constitution, 103 HARV. L. Rev. 43, 46-47, 78, 80-81 (1989) (arguing that the susceptibility of the politically accountable branches to interest group pressure undermines the case for deferential constitutional review); Richard A. Epstein, Toward a Revitalization of the Contract Clause, 51 U. CHI. L. REv. 703, 705-17 (1984) (advocating farreaching substantive judicial review under the Takings and Contract Clauses to curb rent seeking); Jerry L. Mashaw, Constitutional Deregulation: Notes Toward a Public, Public Law, 54 TUL. L. REV. 849, 875 (1980) (using interest group theory to support his argument that the Supreme Court should invalidate some "private-regarding" legislation); Sunstein, supra note 32 , at 52, 85-86 (supporting use of more rigorous constitutional scrutiny to invalidate legislation that rewards the raw political power of interest groups). Scholars have also argued that judges should employ the tools of statutory interpretation to render interest group capture more difficult or less effective. See, e.g., William N. Eskridge, Jr., Politics Without Romance: Implications of Public Choice Theory for Statutory Interpretation, 74 VA. L. REV. 275, 279, 298-99, 303-09, 324-25 (1988) (arguing for narrowly interpreting statutes when the benefits are concentrated and the costs distributed, and broadly interpreting statutes when the benefits are distributed and the costs are concentrated); Cass R. Sunstein, Interpreting Statutes in the Regulatory State, 103 HARV. L. REV. 405, 471, 486 (1989) (advocating narrowly construing statutes that represent interest group transfers). For discussion of the literature, see Elhauge, supra note 151, at 32. 
capture, and those concerns have influenced their decisionmaking. ${ }^{336}$ For example, courts have observed, that, in light of the problem of agency capture and the outsized role of industry in rulemaking process, "if there are policy reasons to exempt federal agencies from ... suits, it is up to Congress to assess them and to determine whether the scope of its sovereign immunity waiver should be revisited." ${ }^{337}$ Other courts have fashioned rules, not found in the text of the APA, to guard against ex parte contacts with powerful interest groups. ${ }^{338}$ Courts could do still more to impose heightened review in similar circumstances. ${ }^{339}$ To that end, legal scholars, in recent work, have sought to reinvigorate arguments for heightened judicial scruti-

336 See, e.g., Adkins v. VIM Recycling, Inc., 644 F.3d 483, 499 (7th Cir. 2011) (citing the risk of agency capture as a justification for holding that a state enforcement action against solid waste facility did not trigger statutory bar against a subsequent citizen suit); Am. Horse Prot. Ass'n, Inc. v. Lyng, 812 F.2d 1, 6 (D.C. Cir. 1987) (finding that an agency's correspondence with representatives of the regulated industry casts doubt on the agency's interpretation of available data and suggested that the agency's refusal to act was not the product of reasoned decision-making); Litton Systems, Inc. v. AT\&T, 700 F.2d 785, 809 n. 36 (2d Cir. 1983) (holding that the "sham exception" to the rule that joint efforts to influence public officials do not violate antitrust laws is applicable in situations of agency capture); Michigan v. U.S. Army Corps of Engineers, 911 F. Supp. 2d 739, 753-54 (N.D. Ill. 2012) (citing the risk of agency capture to support a public nuisance claim against a federal agency). See also Thomas W. Merrill, Capture Theory and the Courts: 1967-1983, 72 CHI.-KENT L. REV. 1039, 1041 (1997) (observing that "most of the innovations [expanding the authority of courts at the expense of agencies] spawned during the 1967-1983 period have endured").

337 U.S. Army Corps of Engineers, 911 F. Supp. 2d at 754. Some scholars have called for a Vermont Yankee II, urging the Supreme Court to rein in perceived undue lower-court interference with agency discretion and autonomy. See Jack Beermann \& Gary Lawson, Reprocessing Vermont Yankee, 75 GEO. WASH. L. REv. 856, 860 (2007) (urging the Court to repudiate a host of court-made rules not found in the text of the APA, including the rule prohibiting agency ex parte contacts and prejudgment in rulemakings to the expanded modern conception of the notice of proposed rulemaking); Richard J. Pierce, Jr., Waiting for Vermont Yankee II, 57 ADMIN. L. REV. 669, 670 (2005) (calling for a Vermont Yankee II to end the First Circuit's then presumption that language in organic statutes calling for a "hearing" in agency adjudications triggers the APA's formal, trial-type adjudicatory procedures); Paul R. Verkuil, Judicial Review of Informal Rulemaking: Waiting for Vermont Yankee II, 55 TUL. L. REV. 418, 418 (1981) (calling for a Vermont Yankee II to put an end to rigorous substantive judicial review of agency policy decisions). To date, the Court has made only minor interventions. Sunstein \& Vermeule, supra note 331, at 394.

338 See e.g., Home Box Office, Inc., 567 F.2d at 51-58. In the years since Vermont Yankee, the D.C. Circuit has effectively limited the prohibition on ex parte contacts to informal rulemakings that resolve conflicting claims among identifiable claimants rather than establish general policy. See Iowa State Commerce Comm'n v. Office of the Fed. Inspector of the Alaska Natural Gas Transp. Sys., 730 F.2d 1566, 1576 (D.C. Cir. 1984); Sierra Club v. Costle, 657 F.2d 298, 401-02 (D.C. Cir. 1981) (discussing whether the court intended Home Box Office to apply to all informal rulemaking procedures).

339 Cf. Douglas H. Ginsburg \& Steven Menashi, Rational Basis With Economic Bite, 8 N.Y.U. J.L. \& LIBERTY 1055 (2014) (arguing for "rational basis with bite" when licensing laws, brought about by interest group lobbying, restrict entry into a field of economic activity). 
ny of laws that discriminate on the basis of wealth or that reflect the political powerlessness of the poor. ${ }^{340}$

\section{Problems with Heightened Judicial Review}

Greater judicial scrutiny is appealing for anyone concerned about wealth's role in governance. Yet, ultimately there are reasons to be wary of relying on the judiciary to reduce the checks and prods imposed by wealth. ${ }^{341}$ For one, while substantial evidence demonstrates the dominance of wealthy interests in governance overall, it is much harder to determine whether wealthy individuals and businesses have dominated in a single case. Likewise, while there is little doubt that governmental policy overall has contributed to rising inequality, it is not always easy to determine if a particular regulation or statutory provision would further concentrate economic and political power.

More importantly, courts may not be particularly effective at making these determinations. Under the adversarial system, courts generally consider only the arguments of the actual litigants. Individuals or organizations interested in the future implications of a case, but not in the judgment itself, generally lack standing and receive inadequate consideration. ${ }^{342}$ Courts also are often not presented with the full array of arguments. And because they focus on the particular parties and adjudicated historical facts before them, courts tend to underweigh, or be underinformed about, the systemic context and consequences of their decisions. ${ }^{343}$

340 See Ross \& Li, supra note 7; see generally Nicholas Stephanopoulos, Political Powerlessness, 90 N.Y.U. L. REV. 1527 (2015) (defining political powerlessness and arguing that the poor are powerless at the federal and state levels).

341 For an excellent elaboration of the problems associated with enhanced judicial review to combat interest group power, see Elhauge, supra note 151. See also NeIL K. Komesar, ImPERFECT Alternatives: ChOOSING Institutions in LAW, ECONOMics, AND PUblic POLICY 98-150 (1994) (making the case for comparative institutional analysis between politics, the market, and courts, and explaining that the groups that are over-represented or under-represented in the political process may also be over-represented or underrepresented, as the case may be, in the courts and in the economic marketplace). For a qualified response, see Thomas W. Merrill, Does Public Choice Theory Justify Judicial Activism After All?, 21 HARV. J.L. \& PUB. POL'Y 219, 229-30 (1997) (arguing that judicial policymaking may be less susceptible to interest group distortions-but only within a narrow range of controversies where each of the contending positions is represented by a group with significant (but not necessarily equal) organization strength, and only when the outcomes reached in these circumstances will not be trumped by a legislated solution).

342 See, e.g., Lujan v. Defenders of Wildlife, 504 U.S. 555, 562-67 (1992) (holding that the prediction of future harm is insufficient to obtain standing). 
Furthermore, even if courts could determine whether the influence of concentrated wealth had resulted in an absence of political checks in a particular instance, or whether a particular policy was likely to further concentrate power with wealth, more intrusive judicial review might not actually redress the problem. ${ }^{34}$ Litigation, like legislation and regulation, is susceptible to wealthy interest group pressures. Litigation is expensive. Well-financed groups are able to litigate more frequently, to influence more effectively the information tribunals receive, and to strategically settle cases that may produce unfavorable precedents. These methods do not require that judges sympathize with any particular view. Rather, they depend on parties' differential abilities to litigate and settle. ${ }^{345}$

Finally, there is also the separate concern that at least some portion of judges might be predisposed to favor wealth. Wealthy interest groups influence judicial appointments and are more likely to do so if judges serve as more general regulators. ${ }^{346}$ And judges, perhaps even more so than elected officials, are drawn from the elite. ${ }^{347}$ Though Article III judges are not subject to the same capture and corruption mechanisms at work in the political branches, they too are likely to bring their own beliefs and experiences to bear on decisions they make. ${ }^{348}$ As with other proposals that would change judicial review to make it less deferential to political outcomes, greater scrutiny of laws here would expand the lawmaking power of the judiciary.

In short, increased judicial review could perversely augment the influence of wealth, further limiting checks on its power. And indeed, business interests have had remarkable success, of late-in cases involving labor rights, health and safety, and consumer protection-in convincing judges on the D.C. Circuit and elsewhere to

344 Elhauge argues that "any defects in the political process identified by interest group theory depend on implicit normative baselines and thus do not stand independent of substantive conclusions about the merits of particular political outcomes." Id. at 34. This is a valid point; however, this Article answers it by offering a baseline norm of a more equal disdistribution of political power on the axis of wealth.

345 See id. at 80. See generally Marc Galanter, Why the "Haves" Come Out Ahead: Speculations on the Limits of Legal Change, 9 LAW \& SOC'Y REV. 95 (1974).

346 Elhauge, supra note 151, at 80-81; Nancy Scherer, et al., Sounding the Fire Alarm: The Role of Interest Groups in the Lower Federal Court Confirmation Process, 70 J. POL. 1026, 1026 (2008).

347 Christopher E. Smith, Judicial Self-interest: Federal Judges and Court ADMINISTRATION 60 (1995) ("Federal judges are already drawn from the ranks of educated political elites.").

348 See id. See generally Nicole E. Negowetti, Judicial Decisionmaking, Empathy, and the Limits of Perception, 47 AKRON L. REv. 693 (2014) (discussing the effects of a judge's prior assumptions, values, and experiences on judicial decisionmaking). Cf. MCCARTY ET AL., supra note 93 , at 55, 76 (explaining the role biases play in interest group votes). 
protect wealth from national regulatory intrusion, even if it means developing new doctrine to do so. ${ }^{349}$

\section{Democratic Institutional Design and the Law of Organization}

\section{From Moderation and Insulation to Participation and Organization}

Though lawyers often look to courts to solve problems, judgemade doctrine can only do so much to diffuse political power. Given the limits of judicial intervention, institutional design may well be a more promising avenue for addressing the dominance of wealth in governance. Existing reform proposals in the constitutional structure literature are, not surprisingly, inadequate to the task. They typically focus on moderating the power of the partisan Executive and on insulating the bureaucracy from partisanship. ${ }^{350}$ Such proposals would do little to diffuse power lodged with wealth. Even if the President's power were reduced, wealthy groups and individuals would continue to have unmatched resources to participate disproportionately in agency meetings and comments, to provide regulators access to vital information, and to appeal to different governmental actors regarding the interpretation of law and regulation. Indeed, it is telling that some independent agencies, structurally insulated from the full extent of presidential power, have suffered capture by organized business interests no less than executive agencies. ${ }^{351}$ Similarly, proposals to amend legal rules and institutions to make political parties more ideologically "moderate," or to strengthen the powers of the minority political party, may be helpful for other reasons, but would be unlike-

349 See e.g., Nat'l Ass'n of Mfrs. v. S.E.C., 748 F.3d 359 (D.C. Cir. 2014) (striking down SEC regulation mandated by the Dodd-Frank Wall Street Reform and Consumer Protection Act, which was designed to require disclosure of the origin of "conflict minerals"); R.J. Reynolds Tobacco Co. v. Food and Drug Admin., 696 F.3d 1205 (D.C. Cir. 2014) (striking down, under commercial speech doctrine, a rule requiring disclosure on cigarette packages); Nat'l Ass'n of Mfrs. v. NLRB, 717 F.3d 947 (D.C. Cir. 2013) (striking down NLRB rule that compelled employers to post a notice that recounts employee rights under existing law and invoking aggressive interpretation of the commercial speech doctrine, as well as agency's statutory authority, to do so).

350 See, e.g., Levinson \& Pildes, supra note 9, at 2376-78 (“[C] onstiutional engineering might focus on insulating the administrative bureaucracy more fully from the partisan pressures of unified government."); Cristina M. Rodriguez, Constraint Through Delegation: The Case of Executive Control Over Immigration Policy, 59 DUKE L.J. 1787, 1826 (2010) ("[T]hough complete insulation from political control may be unattainable ... the structure of an independent agency at least enables tensions between political actors to keep politically motivated decisionmaking at bay.").

351 See Barkow, supra note 153, at 65-66 (using example of Consumer Products Safety Commission to show how a structurally independent agency can be captured). 
ly to diffuse the power of wealth. Indeed, some such proposals are likely to create additional veto points for wealth to exploit.

One obvious place to turn, then, is to proposals to reform campaign finance law, to increase voting rights of less affluent Americans, often disenfranchised in practice if not by rule, ${ }^{353}$ and to increase transparency in politics and government. ${ }^{354}$ These proposals are important and, depending on their form, could help reduce the dominance of both affluent individuals and business entities in politics. ${ }^{355}$

At the same time, these proposals have commanded an undue amount of scholarly attention given their inherent limits. ${ }^{356}$ Reform efforts focused on restricting the flow of money-i.e., on insulating government actors from money's influence-face significant, perhaps even insurmountable, practical hurdles: Money finds new channels

For example, some scholars and elected officials have urged the use of open primaries to generate more moderate nominees and give voters more centrist choices on general election day. Levinson \& Pildes, supra note 9, 2380-81; Charles Schumer, End Partisan Primaries, Save America, N.Y. Times, July 22, 2014, at A21. But see Samuel Issacharoff \& Richard H. Pildes, Politics as Markets: Partisan Lockups of the Democratic Process, 50 STAN. L. ReV. 643 (1998) (arguing that "artificial" barriers to robust partisan competition not be permitted). Another set of proposals is to empower the party out of control to offer criticisms and alternatives to the policies of the party in power and to engage in auditing, investigation, and information-gathering during times of unified government. E.g., Fontana, supra note 49, at 602 (arguing that "government in opposition" rules are necessary to ensure that political minorities have a voice in the democratic process). Scholars urging such reforms also view favorably the Senate filibuster, which empowers the minority in periods of unified government.

353 Daniel Weeks, Why Are the Poor and Minorities Less Likely to Vote?, THE ATLANTIC (Jan. 10, 2014), http://www.theatlantic.com/politics/archive/2014/01/why-are-the-poor-andminorities-less-likely-to-vote/282896/.

354 For example, the Sunlight Foundation urges reforms to make government more accountable and transparent. See http://sunlightfoundation.com/.

355 The separation-of-powers arguments raised in this Article could potentially provide further normative support for the effort to resist the Supreme Court's recent jurisprudence striking down campaign finance regulations. The basic outline of such an approach should be evident from the preceding Parts. In brief: Political competition and the diffusion of political power throughout the polity are independent constitutional values, worthy of protection. Yet the dominance of wealth in politics, combined with rising wealth inequality, degrades political competition in government and concentrates power in too few hands. Unregulated money and laws that burden voting rights of less affluent Americans thus stand in tension with the goals of separated powers. Such an approach is, however, entirely unlikely to prevail in the current Court, and is of limited practical promise, as discussed below.

356 Campaign finance, voting, and lobbying law have received and continue to receive extensive scholarly attention. On campaign finance, see, for example, LESSIG, supra note 6; Post, supra note 6. On voting, see Lani Guinier, No Two Seats: The Elusive Quest for Political Equality, 77 VA. L. REV. 1413 (1991) (using the Voting Rights Act to conceptualize the nature of minority voting exclusion); Pamela S. Karlan \& Daryl J. Levinson, Why Voting is Different, 84 CAL. L. REV. 1201 (1996) (arguing for race conscious districting). On lobbying, see supra note 102. 
when regulators shut down one avenue. ${ }^{357}$ Without additional reforms, simply capping campaign contributions is unlikely to have much effect. Meanwhile, disclosure and transparency regimes have been only minimally effective at identifying the most influential players in politics, while doing little to counter-balance wealth's influence. ${ }^{358}$ And efforts to protect the right to vote at the individual level are unlikely, alone, to redress the significant imbalances in participation and power detailed in this Article: Participation through voting is only one small way in which citizens participate in politics and governance. ${ }^{359}$

The separation-of-powers frame advanced in this Article helps illuminate a complementary path for reform, and one that has received far less attention. If the goal of the Madisonian system is for ambition to counter ambition, law reform should focus on facilitating the participation of countervailing organizations in government, as well as moderating the role of money in campaigns, increasing transparency, and protecting individual voting rights. Reforms aimed at involving groups of citizens in political decisionmaking would work to check and balance power so that one faction does not dominate. This basic approach has a long tradition and many variations. While Madison envisioned the three branches of government countering one another's ambition, other systems have allocated power across informal political substructures, like parties, unions, and social groups, in order to promote democratic decisionmaking. ${ }^{360}$

357 See Samuel Issacharoff \& Pamela S. Karlan, The Hydraulics of Campaign Finance Reform, 77 TEX. L. REV. 1705 (1999) (arguing that money finds new channels when existing routes are closed off); Michael S. Kang, The End of Campaign Finance Law, 98 VA. L. REV. 1, 41 (2012) (detailing recent Court decisions and describing a "reverse hydraulics" whereby the Court rolled back campaign finance law as it stood for decades and "political money has rushed back to newly deregulated channels like water finding its own level"). In recent years, election law scholars have increasingly turned their attention to lobbying law. E.g., Richard Briffault, The Anxiety of Influence: The Evolving Regulation of Lobbying, 13 ELECTION L. J. 160 (2014); Heather Gerken, Keynote Address: Lobbying as the New Campaign Finance, 27 GA. ST. U. L. REV. 1155 (2011); Richard L. Hasen, Lobbying Rent Seeking, and the Constitution, 64 STAN. L. REv. 191 (2011); Zephyr Teachout, The Forgotten Law of Lobbying, 13 ELECTION L. J. 4 (2014).

358 See, e.g., Jennifer A. Heerwig \& Katherine Shaw, Through a Glass, Darkly: The Rhetoric and Reality of Campaign Finance Disclosure, 102 GEO. L.J. 1443 (2014) (finding that compliance with existing disclosure regulations is inconsistent and that the current regime fails to identify the most potentially influential players in the campaign finance system).

359 See supra Part II (detailing mechanisms of participation by wealthy citizens and organizations).

360 LIJPHART, supra note 75, at 9, 25 (contrasting separation-of-powers approaches to other constitutional power-sharing systems); see also AREND LIJPHART, PATTERNS OF DEMOCRACY: GOVERnMENT Forms AND PERFormance In ThIRTY-SiX Countries 181 (1999) (discussing corporatist systems in which interests groups are incorporated into the process of policy 
From this perspective, some existing good-government reforms appear not only unsuccessful but also counter-productive. Certain strategies, while unable in practice to reduce the flow of money, ${ }^{361}$ have actually undermined organized, popularly rooted mobilization. ${ }^{362}$ Limits on coordination, for example, have reduced the ability of popular organizations to join together with political parties and candidates. Other regulations have weakened political party efforts to mobilize new voters. ${ }^{363}$ As a group, these well-intentioned laws have made it harder to draw ordinary people into politics. ${ }^{364}$ Meanwhile, they have done little to counteract the influence wielded by business organizations in lobbying Congress, participating in the regulatory process, and exploiting the revolving door and other mechanisms of influence.

Scholars in election law are increasingly moving away from insulation-or efforts to "level down" campaign spending-and toward "leveling up" reforms aimed at bringing countervailing voices into public debates. Bruce Cain has supported "the Madisonian principle of opposing faction with faction." neutralize political advantage aside from capping and prohibiting is to support countervailing voices." 366 The mechanism he favors, along with other campaign finance scholars and good governance groups, is public financing. Others extend this argument to the lobbying context, arguing that we should find ways to level up by publicly financing lobbyists and making them available to congressional staff. ${ }^{367}$

In the administrative law field, scholars make similar leveling-up arguments. Wendy Wagner argues that institutional design reform should focus on making participation by a diverse range of participants easier, for example by lowering the cost of information and ac-

formation). Cf. Jody Freeman, Collaborative Governance in the Administrative State, 45 UCLA L. REv. 1, 84-85 (1997) (discussing obstacles to and problems with use of corporatist structures in the United States).

361 See Issacharoff \& Karlan, supra note 357; Samuel Issacharoff, On Political Corruption, 124 HARV. L. REV. 118, 120, 125 (2010).

362 SKOCPOL, supra note 5, at 281.

363 Robert F. Bauer, The Right to "Do Politics" and Not Just to Speak: Thinking About the Constitutional Protections for Political Action, 9 DUkE J. CONST. L. \& PUB. POL’Y 67 (2013).

364 SKOCPOL, supra note 5, at 281.

365 Bruce E. Cain, More or Less: Searching for Regulatory Balance, in RACE, REFORM, AND Regulation of the Electoral Process: Recurring PuZzles in AMerican Democracy 263, 277 (Guy-Uriel E. Charles et al., eds., 2011). For a discussion of this shift, see Sachs, supra note 26.

366 Cain, supra note 365, at 277.

367 E.g., Gerken, supra note 357, at 1165-67 (offering several ways for Congress to level up through increasing its own capacity). 
cess. ${ }^{368}$ She urges reforms that would make access and information throughout the regulatory process less costly. ${ }^{369}$ Nina Mendelson has similarly focused on expanding public participation, urging agencies to take large volumes of comments more seriously. ${ }^{370}$

Such proposals to increase participation through public financing, decreasing costs of access, and taking existing mass petitions more seriously are all promising from a separation-of-powers vantage point - they seek to enhance political contestation and provide missing checks on wealthy interests. ${ }^{371}$ Still, these proposals do little to redress the underlying imbalance in organization-an imbalance fundamental to the problem identified in this Article.

Legal interventions designed to facilitate organization are a necessary complement. Indeed, they may even have an important advantage over laws focusing only on individual access. ${ }^{372}$ Reforms aimed at increasing organizational capacity enable under-represented citizens to check and prod as do their wealthier counterparts- to exercise organized political power throughout the processes of politics and government. Organizations permit individuals with low per capita resources to pool resources and speak with a stronger voice. ${ }^{373}$ As

368 Wendy Wagner, The Participation-Centered Model Meets Administrative Process, 2013 WIs. L. REV. 671, 677, 692 (2013) ("In administrative law, agency bureaucrats and appointees are held accountable through a pluralistic system of oversight whereby the affected parties are invited to comment and then have an opportunity to seek judicial review of agency rules that stray outside the authorization of the statute or are arbitrary with respect to the agency's underlying choices. In order to make this administrative law work, however, the full range of affected groups must participate throughout the process without allowing one set of interests to dominate the process and capture the agency.").

369 As Wagner notes, while the costs of commenting on a noticed rule is superficially low, there are multiple points of entry beyond notice and comment. Id. at $686-87$. The period before Notice of Proposed Rulemaking and the process of OIRA review, for example, are less transparent and more costly to access, providing significant opportunities for imbalances in influence. Id. at 688-89.

370 Nina Mendelson, Foreword: Rulemaking, Democracy, and Torrents of E-Mail, 79 GEO. WASH. L. REV. 1343, 1380 (2011).

371 Skeptics of Mendelson's argument express concern that mass comments are groupfacilitated and that signatories might be signing because of group rhetoric. Mendelson correctly retorts that excluding rulemaking comments because groups are involved or rhetoric is used would leave very few comments, but the problem is deeper than that: group participation should be encouraged and facilitated, not feared. Id. at 1372-73.

372 Benjamin Sachs has made this point in arguing for labor law reform. Sachs, supra note 26 , at $171-75$.

373 See Joshua Cohen \& Joel Rogers, Secondary Associations and Democratic Governance, 20 POL. \& SOC'Y 393, 424 (1992); see also 1 Joshua CoHen \& Joel Rogers, Associations AND DEMOCRACY: THE REAL UtOPIAS PROJECT 126-27 (Erik Olin Wright, ed. 1985) (discussing how associative democracy based on non-governmental social groups could mitigate inequality, assist underrepresented interest groups, and protect individual liberties); JOHN D. Stephens, The Transition from Capitalism to Socialism 49-50 (Michael Mann ed., 
Benjamin Sachs writes, "a well-organized political group can mobilize voters and influence elections; it can lobby and influence legislation; it can buy media time and influence public opinion." ${ }^{374}$ Wellorganized groups can also help shape regulatory agendas, comment on proposed rules, press for agency enforcement activity and so on. And to the extent such organizations are membership groups, rather than professionally managed "check-book" organizations, their participation helps facilitate more representative and diffuse political involvement. Organizations funded by and directed by a range of Americans, representing their interests, can provide checks and prods now often missing.

An organization-focused approach is supported by both historical and empirical evidence. Historians have illuminated the instrumental role played by mass membership organizations in the passage of wage and hour laws, labor legislation, progressive taxes, and civil rights legislation, even in the face of staunch opposition from wealth. ${ }^{375}$ More recent empirical work also supports the conclusion that organization is essential to our basic system of fighting faction with faction. ${ }^{376}$ Martin Gilens, for example, finds an exception to the general rule that policy makers are far more responsive to the interests and preferences of the wealthy: Where countervailing interest group power is exerted, government policy no longer simply tracks the preferences of the wealthy. ${ }^{377}$ Rather, on issues where organized groups advance the preferences of low- and middle-income Americans, government outcomes more often correspond to the preferences of low- and middle-income Americans. ${ }^{378}$ Consistent with these findings, the state and local governments that have been most active in attempting to redress wealth inequality of late are those operating in regions with higher levels of organization among working people. $^{379}$ Recent experience regarding presidential executive orders,

1979) (discussing the importance of labor unions and other organizations in strengthening the welfare state and facilitating movement from capitalism to socialism); David Bradley et al., Distribution and Redistribution in Postindustrial Democracies, 55 WORLD POL. 193, 197 (2003) ("Organization in unions results in a shift of power in the market toward the union members.").

374 Sachs, supra note 26 , at 167.

375 Lichtenstein, supra note 181 , at 122-27.

376 See Sachs, supra note 26, at 167-68.

377 GILENS, supra note 191, at 121, 157-58.

378 Id. For example, Martin Gilens found that unions are among the most important forces moving policy in a direction desired by the less well off. Id. at 158 .

379 In 2014, the Seattle City Council voted unanimously to raise the minimum hour wage to $\$ 15$. Seattle, WA., Code ch. 14.19 (2014). In 2013, union members accounted for $18.9 \%$ of wage and salary workers in Washington State, almost six percentage points 
such as the issuance of the labor executive orders following activity by worker groups, further supports the conclusion that countervailing organization can diffuse concentrated power. ${ }^{380}$

\section{Building Countervailing Organization}

How then might legal and institutional reforms facilitate broader and more equitable participation in organized political life? How might countervailing organizations be brought into governance? A full exploration of that question obviously cannot be tackled in the remaining pages of this Article. In separate work, I will examine the extent to which our civil society deficit is not simply a political problem, as is typically understood, but also a legal problem-a product of legal structures that discourage or inadequately facilitate organization-with possible legal solutions. Here, I identify several strategies, drawn from disparate fields in law and policy, worth further exploration.

First, administrative law and process could do more to provide a formal role in governance for public interest organizations, particularly organizations that derive high proportions of funding from membership contributions (from natural persons) and have members who enjoy rights to participate in associational decisionmaking. Rather than simply lowering the barrier to enter the political or governing process and hoping that lower-income individuals or underresourced organizations take advantage, membership organizations could be assigned more prominent roles of participation. This could be done through any number of routes, such as soliciting their participation in congressional hearings, Federal Advisory Committees, and in meetings with OIRA, the Domestic Policy Council, and other administrative offices. In addition to involving organizations in notice and comment, agencies could also establish mechanisms to solicit input from membership associations regarding regulatory agendas and proposed rules. Legislative offices could do the same. Consumer

above the national average of $11.3 \%$. Press Release, Bureau of Labor Statistics, Union Membership in Washington-2013 (Feb. 27, 2014), http://www.bls.gov/regions/west/newsrelease/2014/pdf/unionmembership_washington_20140227.pdf. In California, where the Los Angeles City Council is considering whether to raise the minimum wage to $\$ 15.25$ an hour by $2019,16.4 \%$ of workers were union members in 2013. Press Release, Bureau of Labor Statistics, Union Membership in California-2013 (Feb. 27, 2014), http://www.bls.gov/regions/west/news-release/2014/pdf/unionmembership_ california_20140226.pdf; Emily Alpert Reyes, Nine things to know about boosting the minimum wage in L.A., L.A. TIMES (Mar. 24, 2015, 10:17 AM), http://www.latimes.com/local/ lanow/la-me-ln-minimum-wage-20150324-story.html. 
empowerment programs advocated by such scholars as Ian Ayres and John Braithwaite, or new governance models, such as those advocated by Charles Sable and William Simon, offer a variation of this approach. ${ }^{381}$ These programs have been successful, although not uniformly so, at creating countervailing checks in the regulatory process. ${ }^{382}$ They could potentially be more so if targeted at organizations with a membership, rather than a management, character, ${ }^{383}$ and if uncoupled from a strongly market-oriented approach to regulation.

Public interest organizations could also be involved in helping agencies achieve compliance with the law. For example, Janice Fine and Jennifer Gordon demonstrate how labor inspectorates that have given organizations like unions and worker centers a formal, ongoing role in enforcement in low-wage sectors have had greater success. ${ }^{384}$ While Fine and Gordon's aim is to achieve greater legal compliance, involving civil society in enforcement efforts could also serve to strengthen political competition and to diffuse power: It provides agency officials the perspectives of a different segment of the population and counteracts capture by well-funded industry groups. Furthermore, involving membership associations more directly in setting policy agendas, developing policy ideas, and achieving compliance makes it more worthwhile for ordinary Americans to join the discussion. $^{385}$

Second, to make such governance reforms work, organizations representing low- and middle-income Americans must be much more prevalent. To that end, the revitalization of worker organizations is essential. As previously discussed, among the interest groups operating in the United States today, labor unions' policy positions are most closely associated with the preferences of the less well-off. ${ }^{386}$ In the United States, unions have successfully organized lower- and middle-

\footnotetext{
381 See, e.g., IAn Ayres \& John Braithwaite, Responsive Regulation: Transcending the DeREGUlATED Debate 15-16 (Donald R. Harris et al. eds., 1992) (proposing regulatory regimes more responsive to industry and consumer associations); Charles F. Sabel \& William H. Simon, Minimalism and Experimentalism in the Administrative State, 100 GEO. L.J. 53, 56 (2011) (analyzing minimalist and experimentalist models of public intervention).

382 For an analysis of potential problems with empowerment of stakeholders as a means of creating collaborative government and a discussion of the contexts in which collaborative governance has been most successful, see Mark Seidenfeld, Empowering Stakeholders: Limits on Collaboration as the Basis for Flexible Regulation, 41 WM. \& MARY L. REV. 411, 413 (2000). See id. at 500 (emphasizing need for interest group internal democracy).

384 Janice Fine \& Jennifer Gordon, Strengthening Labor Standards Enforcement through Partnership with Workers' Organizations, 38 POL. \& SOC'Y 552, 559 (2010).

385 SKOCPOL, supra note 5, at 290.

386 Sachs, supra note 26, at 168-69 (quoting GiLENS, supra note 191). For further discussion, see supra note 85 and accompanying text.
} 
income Americans for political action to greater extent than any other non-party actor. Though their track record has been checkered, they constitute some of the few mass-membership organizations remaining. Meanwhile, there are indications that recent efforts by the labor movement are more focused on political action and class-based legislation, and less focused on site-by-site organizing and bargaining. ${ }^{387}$

Building on those efforts, labor law should be reformed to encourage worker organizations and to facilitate their active participation in politics and governance. While scholars have offered a host of labor law reform proposals, few have focused their attention specifically on the political capacity of worker organizations. ${ }^{388}$ More thought is needed on that subject, as well on how law can facilitate organization among low- and middle-income Americans in contexts other than the workplace, including in schools, public benefit offices, churches and other religious institutions, and community based organizations. $^{389}$

Third, political parties could be redesigned to strengthen the role of rank-and-file members and to shift the balance away from elites. To that end, some scholars have suggested that we reform campaign finance law to channel contributions back to the formal political parties and away from large-donor governed "shadow parties" like Super PACs. ${ }^{390}$ Others advocate amending political law to ease restrictions on grassroots organizing and coordination. ${ }^{391}$ Reinvigorated political parties might not lead to less partisanship, but they could enhance government accountability. Indeed, as Walter Dean Burham has argued, strong, participatory parties with coherent ideologies help gov-

387 Kate Andrias, Law and the Labor Question in the Post New Deal Order: Reasoning from the Fight for $\$ 15$ (Univ. of Cal. Santa Barbara, Beyond the New Deal Order Conference, Sept. 2426, 2015) (on file with author).

388 Benjamin Sachs' "unbundled union" proposal is a notable exception. Sachs, supra note 26, at 153, 155 (arguing that opposition to collective bargaining impedes unions' ability to serve as a political-organizing vehicle for lower- and middle-income groups and advocating an "unbundled labor law" that would allow workers to form a "political union," which would be barred by statute from engaging in collective bargaining, but would be able to serve as a vehicle for collective political voice for workers who decided to join).

389 For some tentative ideas on how law might facilitate organization among low-income Americans, see Sachs, supra note 26.

390 See Fishkin \& Gerken, supra note 175 at 179, 211-12 (analyzing McCutcheon's impact on campaign-finance, namely the facilitation of shadow parties and their resulting implications for party politics); Fishkin \& Gerken, supra note 185, at 32-33 (describing the rise of shadow parties and decline of the formal political parties).

391 See Bauer, supra note 363, at 81-82 (arguing for greater consideration of "doing politics" instead of merely focusing on speech in the context of campign-finance jurisprudence). 
ernment minimize the influence of powerful, rent-seeking economic interests. $^{392}$

Fourth, we could unfetter the political activity of existing membership associations by reforming tax law. Under the current regime, non-profit organizations are penalized for engaging in political activity and they receive little benefit from being representative in structure. Law reforms could alter existing incentives. For example, rules designed to create firewalls in non-profits between partisan and nonpartisan activities could be repealed. Tax law could provide incentives for associations that derive high proportions of funding from natural-person membership contributions and have members who enjoy rights to participate in associational decision-making. ${ }^{393}$

An obvious objection to these proposals is that if wealth is so powerful, no such changes could ever be enacted. The critique is true to a point. Significant reform is unlikely in the current political environment. But as this Article has acknowledged, the power of wealth ebbs depending on circumstance and alignments: When issues become particularly salient, the power of wealthy individuals and their organizations can be overcome and their views can shift. ${ }^{394}$ And, indeed, in recent months it appears that public concern about economic inequality is mounting, creating pressure on elected officials, Democrat and Republican, to respond. ${ }^{395}$ The goal is to suggest that if and when significant political and governance reform becomes pos-

392 WAlter DeAn Burham, Critical Elections AND the Mainsprings of AMERican POLITICS 130-33 (1970) (arguing that strong parties with coherent ideologies are an important mechanism by which the government can minimize the influence of powerful, rent-seeking economic interests).

393 See, e.g., Dana Brakman Reiser, Dismembering Civil Society: The Social Cost of Internally Undemocratic Nonprofits, 82 OR. L. REv. 829, 831-32, 892-93 (2003) (discussing the significant social costs of a trend away from member-driven organizations and suggesting tax benefits for membership organizations as one of several potential responses to mitigate these costs).

394 For example, in November 2010, the House voted to ban the special-purpose spending provisions known as earmarks from being inserted in legislation. Jennifer Steinhauer, House Republicans Back No-Earmarks Rule, N.Y. Times THE CAUCUS (Nov. 18, 2010, 1:13 PM), http://thecaucus.blogs.nytimes.com/2010/11/18/house-republicans-back-noearmarks-rule/.

395 See Amy Chozick, Economic Plan Is a Quandary for Clinton '16, N.Y. TimEs, Feb. 8, 2015, at A1; Jonathan Weisman \& Ashley Parker, Talk of Wealth Gap Prods the G.O.P. to Refocus, N.Y. TIMES, Jan. 22, 2015, at Al (detailing the shift in the traditional Republican narrative around economic inequality in the 2016 presidential election campaign); Patrick O'Connor, 2016 Populism on Left or Right Worries Chamber of Commerce, Wall ST. J. WASHINGTON WIRE (Dec. 31, 2014, 10:07 AM), http://blogs.wsj.com/washwire/2014/12/ 31/2016-populism-on-left-or-right-worries-chamber-of-commerce/ (exploring the Chamber of Commerce's concerns about the 2016 presidential campaign's emphasis on economic disparities). 
sible, it should focus beyond efforts at insulation from, and moderation of, partisanship, and even beyond efforts to control campaign money, to reforms that would shift long-term distribution of political and economic power.

Whether any of the particular strategies identified above is worth pursuing depends on their attendant costs to other democratic values and on the relative merits of institutional and doctrinal alternatives. Greater participation, for example, does not always lead to greater organization. For present purposes, however, the goal is to highlight the intimate relationship between constitutional structure and the role of organization in American civic and political life. The rules that structure American organizations should be seen as an essential complement to the Article I and Article II provisions creating the competing interests of the political branches-and they should be seen as no less foundational to constitutional governance than the political parties and the internal bureaucracy.

\section{CONCLUSION}

Leading constitutional law theorists and many public commentators worry intensely about the nefarious impact partisanship has had on our system of constitutional governance, and particularly on the expansion of the executive and the impotence of Congress. Americans, they argue, must, if nothing else, overcome political polarization. Those who study the internal workings of the executive branch agree, though they are more optimistic; they promise that bureaucracy and internal checks offer a shield against partisanship, gridlock, and the unbound executive. While both of these accounts have considerable purchase, their failure to consider how wealth systematically shapes the branches, the parties, and the executive's internal mechanisms leads to descriptive oversights. Whatever one's normative take, executive power, legislative gridlock, and internal executive branch checks cannot be understood absent a political economy analysis.

But while the primary goal of this Article has been critical and descriptive, the claim is also normative: Even when partisan and internal executive branch checks are in place, power is concentrated in too few hands-in ways detrimental to liberty, governmental efficacy, and, particularly, democratic accountability. Ultimately, if such goals remain aspirations of American government, reforms encouraging the participation of not only individuals but also countervailing organizations are paramount. This Article has only suggested some potential reforms to that end. The project of thinking them through is all the more urgent as inequality soars, membership in labor organi- 
zations declines, and the voices of middle- and lower-income Americans become fainter throughout the political and governing process. 